\title{
Avaliação da contribuição para a área de Vigilância Sanitária de Alimentos de pesquisas realizadas em Programas de Pós-Graduação Strictu Sensu da Universidade de São Paulo
}

Vanessa Fernandes Ribeiro

Dissertação apresentada ao Programa de Pós-Graduação em Saúde Pública da Faculdade de Saúde Pública da Universidade de São Paulo para obtenção do título de Mestre em Saúde Pública.

Área de Concentração: Serviços de Saúde Pública

Orientação: Prof. Dr. Glavur Rogerio Matté

São Paulo 2008 
É expressamente proibida a comercialização deste documento tanto na sua forma impressa como eletrônica. Sua reprodução total ou parcial é permitida exclusivamente para fins acadêmicos e científicos, desde que na reprodução figure a identificação do autor, título, instituição e ano da tese/dissertação. 


\section{Dedicatória}

Dedico este trabalho aos meus avós e padrinhos: Dalva Luciano e Miguel Strauss; verdadeiros Anjos de Deus aqui na Terra! O6rigada por todo o apoio, incentivo, por sempre terem acreditado em mim, investido em meu potencial e em meus sonfos. Cada conquista minha é de vocês também.

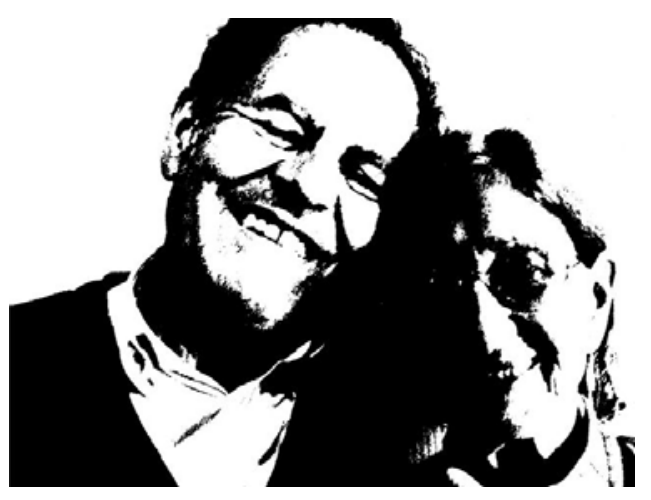

Amo vocês! 


\section{Agradecimentos}

"Muitas são, Senhor, meu Deus, as maravilhas que tens operado para conosco, e os teus pensamentos não se podem contar diante de ti; eu quisera anunciá-los e manifestá-los, mas são mais do que se podem contar." (Salmo 40:5)

Agradeço, primeiramente, a $\underline{D}$ EUS por me conceder mais esta dádiva, por me proteger e me guiar em cada dia da minha vida. Sou grata pela força e por me manter perseverante, principalmente, nos momentos de incerteza e desafios. Sem $\underline{E L E}$, nada seria possivel!

À Mamãe Eliane Maria Arruda... Por sempre me transmitir amor, otimismo, esperança e fé. Obrigada por ser a pessoa mais maravilhosa desse mundo para mim, por tu ires muito além do que significa a palavra "MÃAE". Tu és uma fonte inesgotável de amor incondicional, dedicação e desprendimento. Se, um dia, eu for para meus filhos metade do que tu és me sentirei realizada.

Ao Papai Sebastião Fernandes Ribeiro... O meu querido "Tata". Como diz a música: "Pai, você foi meu herói (...), hoje é mais, muito mais do que um amigo". Os "tropeços" da vida não são mais importantes do que o amor que nos une. Obrigada por voltar a se fazer presente nessa fase tão importante de minha vida. Agradeço todo o apoio, conselhos, incentivo e orações.

À minha irmã Andressa Fernandes Ribeiro... Obrigada por me apoiar e incentivar, por me auxiliar na revisão do texto, por fotografar nossos avós e editar a foto que aparece na dedicatória. Mas agradeço, principalmente, por tu sempre estares ao meu Cado! Orgulho-me muito de tê-la como irmã. 
Ao Prof. Dr. Glavur Rogerio Matté... Obrigada pelas orientações, pelos conhecimentos $e$ as experiências compartilhados, tão fundamentais para esse trabalho, por toda a paciência (e que paciência!) que teve comigo e pelos "puxões de orelha" necessários. Agradeço, mais ainda, a oportunidade de realizar este mestrado $e$, principalmente, por expandir meus horizontes e fazer-me compreender que a Vigilância Sanitária ia muito além do que a minha "cabecinha" poderia imaginar.

Ao Dr. Eneo Alves da Silva Ir... Saiba que o tenho como meu exemplo maior de dedicação e profissionalismo, desde os meus tempos da graduação. És o responsável por ter me despertado o interesse pelo Controle Higiênico-Sanitário de Alimentos. Obrigada pelos conselhos, pelo auxílio, por se mostrar sempre solícito, e pelas dicas imprescindíveis. "Quando eu crescer, quero ser igual a ti!" (-)

À Profa. Dra. Maria Cristina da Costa Marques... Obrigada pelos valiosos conhecimentos repassados durante suas disciplinas. Nãa só o conhecimento teórico, mas sim, experiências de vida dentro da área de Vigitância Sanitária. Agradeço as dicas e sugestões pontualíssimas na banca de qualificação. Tu, também, és peçachave na realização deste trabalho.

Ao Prof. Dr. Alexandre Bella Cruz... Jamais esqueceria de ti! Se concluo este trabalho, foi porque tu me amparastes lá na graduação. Agradeço imensamente por me apresentar ao "vasto mundo da microbiologia", pela oportunidade que me destes de desenvolver um projeto de iniciação científica, por me incentivar e me nortear em pesquisas extracurriculares. A experiência e os conhecimentos que tu transmitiste me são válidos até hoje. 
Aos tios Antônio Pedro Ribeiro e Ana Maria Ribeiro, e à prima Ana Laura Ribeiro... Obrigada por terem me acolfido na casa de vocês no início do mestrado, quando eu ainda não tinha lugar para morar. O que vocês fizeram por mim não háo que pague! Que Deus os recompense imensamente.

À prima Kelly Cristina Sessa... Obrigada pela parceria, pela amizade, pelas risadas, por me ouvir sempre que precisei, por se preocupar comigo, me aconsethar e por sempre estar disposta a ajudar. Tu não tens idéia, mas tornastes minha vida aqui em São Paulo menos solitária e muito mais colorida.

À amiga "de sempre", desde os tempos da infância, Priscila Krawczun... $\mathcal{E}$ pensar que nós já temos quase 1/4 de século de amizade! Obrigada por todo o apoio, incentivo e auxílio que me destes, principalmente no início do mestrado. Tu és o modelo maior de coragem, perseverança e otimismo perante os obstáculos que levarei sempre comigo.

Ao "Seu" Raimundo Francisco da Cunha, porteiro da Biblioteca da FSP... Obrigada pelas conversas, pela companhia nos almoços no refeitório, por secar várias lágrimas minhas, por sempre me fazer sorrir quando estava triste, por me fazer acreditar em mim mesma quando eu já não mais acreditava.

Ao amigo José Homero Damico Ir... Agradeço por sua amizade, pelas caminhadas, por sempre estar disposto a estender a mão para me ajudar, por todo apoio e força que me destes na conclusão deste trabalho e, também, na elaboração do abstract. 
À tia Iara Regina Arruda... Agradeço por se fazer presente em minha vida, mesmo distante. Obrigada por se preocupar e se importar comigo e por interceder por mim em orações.

Ao Artemir Coelho de Brito e Flavio Issao Vehara... Agradeço pela amizade e parceria durante o período de mestrado.

E, finalmente, meu gatinho Mingau... Obrigada por me alegrar todos os dias e pela companfia incansável durante os dias (e noites!) em que concluí este trabalfo.

Muito obrigada!

Que DEUS os guarde e os proteja por todo o sempre. Amo vocês de coração... TODOS! 
Este trabalho é dedicado à memória de:

Benedito Fernandes Ribeiro José Fernandes Ribeiro Luiza Correa Raizer Maria Aparecida Fernandes Ribeiro Maria Benedita Ribeiro Pedra Geremias Luciano Se6astião Arruda 
"Mas os que esperam no Senhor renovarão as suas forças $e$ subirão com asas como águias; correrão e não se cansarão; caminharão e não se fatigarão"

(Isaías 40:31) 
Ribeiro VF. Avaliação da contribuição para a área de Vigilância Sanitária de Alimentos de pesquisas realizadas em Programas de Pós-Graduação Strictu Sensu da Universidade de São Paulo. [dissertação de mestrado]. São Paulo: Faculdade de Saúde Pública da USP; 2008.

\section{Resumo}

Introdução - A Vigilância Sanitária e a legislação de alimentos vivenciaram significativas mudanças nas últimas décadas em virtude dos órgãos governamentais e às constantes pesquisas científicas, ressaltando a importância da integração entre Universidade e Vigilância Sanitária a fim de promover intervenções que se adequem à realidade do país e às novas necessidades da população brasileira. Objetivo - Avaliar a contribuição do conhecimento oriundo de pesquisas científicas, de cursos de PósGraduação Strictu sensu da Universidade de São Paulo, com potencial de aplicação na área de Vigilância Sanitária de alimentos. Métodos - Foram analisadas 337 teses e dissertações publicadas pela Universidade de São Paulo entre os anos 1993 e 2007. Para revisão de literatura e aprofundamento da discussão, foram selecionadas publicações científicas de acordo com o tema e relevância bem como dispositivos legais relacionados ao controle sanitário de alimentos. Resultados e Considerações Finais - Observou-se a importância da integração entre Universidade e Vigilância Sanitária de Alimentos no fornecimento subsídios que permitam capacitar e munir os profissionais dessa área, norteando práticas coerentes através de informações que venham servir de base e orientação para a evolução das ações de Vigilância Sanitária.

Descritores: Vigilância sanitária; Alimentos; Legislação; Universidade de São Paulo; Pós-graduação. 
Ribeiro VF. Evaluation of the contribution for Food Health Surveillance of researches carried out in post graduation Strictu Sensu programs of the University of São Paulo. [dissertation] São Paulo: Faculdade de Saúde Pública da USP; 2008.

\begin{abstract}
Introduction - The Health Surveillance and the food legislation had, in the last decades, experienced significant changes due to governmental departments and constant scientific researches, standing out the importance of the integration between the University and the Health Surveillance to promote interventions that adjust to the reality of the country and the new necessities of the Brazilian people. Objectives - Evaluate the contribution of the deriving knowledge of scientific research, from Strictu Sensu's postgraduation programs from University of Sao Paulo, with potential application in Food Health Surveillance. Methods - 337 thesis and dissertations have been analyzed, all published by the University of Sao Paulo between 1993 and 2007. To review the publications and get deeper in the theme the material was selected by subject, relevancy, and legal aspects related to the food sanitary control. Results and Conclusion - Became clear that the integration from the University and the Health surveillance have an important role on the improvement of the workers in this area, keeping the consistency on the practices, providing informations that can help them to evolve the necessary actions.
\end{abstract}

Descriptors: Health surveillance, Food, Legislation, University of Sao Paulo, Post-graduation. 


\section{ÍNDICE}

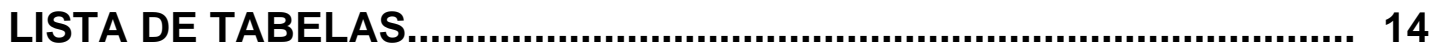

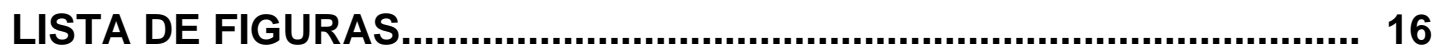

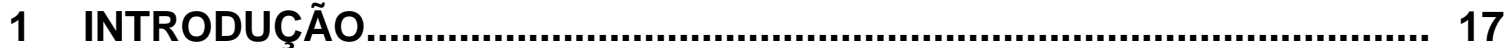

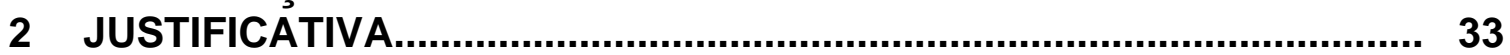

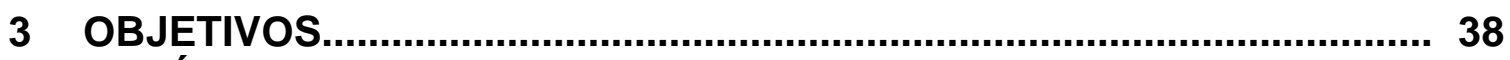

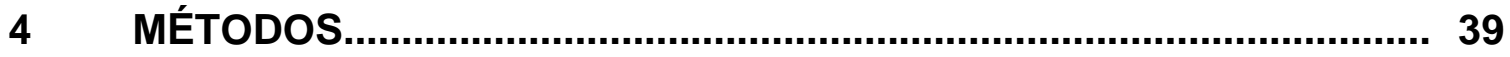

4.1 Etapas da pesquisa científica..................................................... 39

4. 2 Delimitação do tema............................................................... 39

4. 3 Seleção das fontes bibliográficas.............................................. 40

4.3.1 Base informatizada local............................................... 40

4.3.2 Bases de dados nacionais e internacionais........................ 42

4.3.3 Outras fontes............................................................ 43

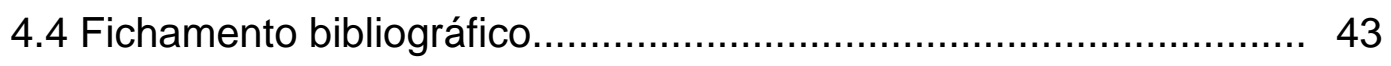

4.5 Compilação das referências bibliográficas.................................... 44

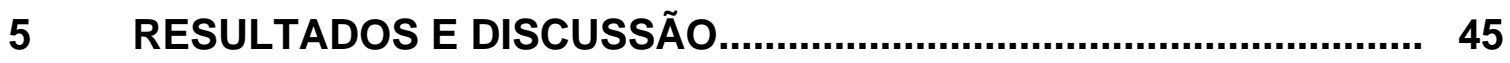

5.1 Caracterização da amostra estudada........................................... 45

5.2 Distribuição das teses e dissertações, de 1993 a 2007, de acordo com o(s) objetivo(s) de pesquisa................................................... 48

5.2.1 Análise microbiológica de alimentos................................... 50

5.2.1.1 Microrganismos mais comumente pesquisados nas teses e dissertações.

5.2.1.2 Métodos convencionais e métodos moleculares utilizados para pesquisa de microrganismos em alimentos. e dissertações.

5.2.1.3 Alimentos mais comumente pesquisados nas teses

5.2.1.4 Alimentos pesquisados que apresentaram algum nível de contaminação microbiológica.

5.2.3 Análise físico-química, nutricional e sensorial de alimentos... 77

5.2.4 Conservação de alimentos................................................ 79

5.2 .5 Irradiação de alimentos....................................................... 83

5.2.6 Análise de resíduos em alimentos..................................... 89

5.2.7 Análise de Perigos e Pontos Críticos de Controle

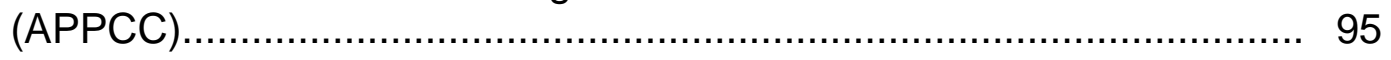

5.2.8 Análise de procedimentos higiênicos.................................... 99 
5.2.9 Análise do processamento mínimo de alimentos

5.2.10 Pesquisa de consumo alimentar

5.2.11 Análise de alimentos transgênicos.

5.2.12 Análise da rotulagem de alimentos.

5.2.13 Avaliação de surtos alimentares.

5.2.14 Análise da oxidação lipídica em alimentos.

5.2.15 Análise do reuso da água.

5.2.16 Análise dos aspectos conceituais e operacionais da Vigilância Sanitária.

5.2.17 Outras categorias.

5.2.17.1 Comparação entre os efeitos dos cultivos orgânico e convencional.

5.2.17.2 Caracterização do perfil de profissionais que treinam manipuladores.

5.2.17.3 Detecção de autenticidade ou adulteração de alimentos.

5.2.17.4 Avaliação da biodisponibilidade de nutriente sintético e natural.

5.2.17.5 Desenvolvimento de metodologia para determinação de ácidos graxos trans

5. 3 A relação entre a Universidade e a Vigilância Sanitária

6 CONSIDERAÇÕES FINAIS.

\section{ANEXOS}

Anexo 1 - Referências bibliográficas das teses e dissertações analisadas na pesquisa.

Anexo 2 - Primeira página do Currículo Lattes da autora. 


\section{LISTA DE TABELAS}

Tabela 1 - Distribuição das teses e dissertações analisadas, de 1993 a 2007, de acordo com a unidade de ensino.

Tabela 2 - Distribuição das teses e dissertações, de 1993 a 2007, de acordo com o(s) objetivo(s) de pesquisa.

Tabela 3 - Distribuição das teses e dissertações, de 1993 a 2007, de acordo com o tema "Análise Microbiológica de Alimentos"......

Tabela 4 - Microrganismos alvos de pesquisa das teses e dissertações, de 1993 a 2007

Tabela 5 - Alimentos mais comumente analisados pelos pósgraduandos em suas teses e dissertações, entre os anos de 1993 a 2007.

Tabela 6 - Análises microbiológicas, realizadas em produtos lácteos, de acordo com dados obtidos de dissertações e teses realizadas na Universidade de São Paulo, publicadas entre 1993 e 2007.

Tabela 7 - Análises microbiológicas, realizadas em pescados e frutos do mar, de acordo com dados obtidos de dissertações e teses realizadas na Universidade de São Paulo, publicadas entre 1993 e 2007.

Tabela 8 - Análises microbiológicas, realizadas em produtos cárneos, de acordo com dados obtidos de dissertações e teses realizadas na Universidade de São Paulo, publicadas entre 1993 e 2007. 
Tabela 9 - Distribuição das teses e dissertações, de 1993 a 2007, de acordo com o tema "Análise físico-química, nutricional e sensorial de alimentos"

Tabela 10 - Distribuição das teses e dissertações, de 1993 a 2007, de acordo com o tema "Conservação de alimentos".

Tabela 11 - Distribuição das teses e dissertações, de 1993 a 2007, de acordo com o tema "Irradiação de alimentos".

Tabela 12 - Distribuição das teses e dissertações, de 1993 a 2007, de acordo com o tema "Análise de resíduos em alimentos"....

Tabela 13 - Distribuição das teses e dissertações, de 1993 a 2007, de acordo com o tema "APPCC".

Tabela 14 - Distribuição das teses e dissertações, de 1993 a 2007, de acordo com o tema "Análise de procedimentos higiênicos". 


\section{LISTA DE FIGURAS}

Figura 1 - Distribuição das teses e dissertações analisadas, de 1993 a 2007, por ano de publicação

Figura 2 - Distribuição das teses e dissertações analisadas de 1993 a 2007, de acordo com o método microbiológico utilizado. 


\section{INTRODUÇÃO}

A qualidade higiênico-sanitária como fator de segurança alimentar é um desafio atual e vem sendo amplamente estudada e discutida, uma vez que as doenças transmitidas por alimentos é um dos principais fatores contribuintes para os índices de morbidade em países latino-americanos (VALENTE e PASSOS, 2004; AKUTSU et al., 2005). Com isso, o controle de qualidade de alimentos tornou-se objeto de uma constante evolução e crescente ênfase vem sendo dada ao problema de segurança alimentar nos últimos anos, principalmente no tocante a proteção da saúde do consumidor e utilização de conhecimentos científicos em estabelecimento de padrões, especificações e recomendações aplicadas ao controle de alimentos, visando produzir e oferecer alimentos de acordo com as normas específicas de Vigilância Sanitária (FREO e REOLON, 2006).

A Vigilância Sanitária é uma prática social de expressiva relevância pública, de inclusão e construção da cidadania, se afirmando cada vez mais como um condicionante imponente para o direito à saúde, proclamado pela Organização das Nações Unidas (ONU) na Declaração Universal dos Direitos Humanos de 1948 (SANTOS e BITTENCOURT, 2005). Esse segmento desempenha um importante papel dentro dos princípios básicos de saúde, estando a mesma explicitada no art. $6^{\circ}$ da Lei Federal 8080/90, em que estabelece: "o conjunto de ações capaz de eliminar, diminuir ou prevenir riscos à saúde e de intervir nos problemas sanitários decorrentes do meio ambiente, da produção e circulação de bens e da prestação de serviços de interesse da saúde" (PEIXOTO et al., 2006).

Com o propósito de proteger o consumidor contra a ingestão de alimentos nocivos, os países vêm ao longo da história, buscando 
mecanismos organizacionais e instrumentalização das ações em saúde pública (MIGUEL et al., 2000).

As ações de saúde no campo da Vigilância Sanitária existem há milhares de anos (ROZENFELD, 2000; BUENO, 2005) e os alimentos sempre fizeram parte das preocupações de órgãos governamentais e epidemiológicos, em virtude de suas propriedades, por serem uma rica fonte de nutrientes para o desenvolvimento de microrganismos (MEZOMO, 2002) e, também, por serem alvo fácil de práticas desonestas por parte dos comerciantes (ROSEN, 1994).

Em nosso país, a história do controle sanitário se deu na época do Brasil-Colônia e o controle baseava-se no modelo existente em Portugal (ROZENFELD, 2000; BUENO, 2005). Com a chegada da família real portuguesa, no ano de 1808, o Brasil sofreu profundas mudanças no âmbito capitalista mundial, passando a fazer parte das rotas comerciais inglesas e de outras "nações amigas", intensificando o fluxo de embarcações e a circulação de passageiros e mercadorias; aumentando, assim, a necessidade de controle sanitário, para que fossem evitadas as doenças epidêmicas e para aumentar a aceitação dos produtos brasileiros no mercado internacional (COSTA, 2004; BUENO, 2005).

A instauração da República foi um marco no início da organização das administrações sanitárias estaduais e a constituição de órgãos de Vigilância Sanitária nas Unidades da Federação (ROZENFELD, 2000). Com a Reforma Carlos Chagas, criou-se o Departamento Nacional de Saúde Pública (DNSP) através do Decreto-Lei $n^{\circ} 3.987$, de 1920, que substituiu a Diretoria Geral de Saúde Pública, criada em 1897. O DNSP estendeu a sua ação ao saneamento urbano e, formalmente, ao rural. Infelizmente, essas 
ações tinham pouco alcance, em virtude das limitações do país (COSTA, 2004; BUENO 2005).

Durante o período do Estado Novo, surgiu o Decreto $n^{\circ}$ 19.604/31 que reafirmava como crime, sujeito às penalidades previstas no Código Penal dar, vender, e expor ao consumo público gêneros alimentícios fraudados (COSTA, 2004).

A partir do começo da década de 60, a área de alimentos passou a sofrer influência do Codex Alimentarius internacional, que reúne normas para o comércio internacional de alimentos e estimula o controle sobre os riscos relacionados ao consumo desses produtos e defesa do consumidor (ROZENFELD, 2000; BUENO, 2005).

A instituição do Código Brasileiro de Alimentos (CBA) pelo DecretoLei $n^{\circ}$ 209/67 trouxe grandes modificações no painel normativo na área de alimentos. Esse Código continha as normas de defesa e proteção da saúde individual e coletiva, desde a produção até o consumo de alimentos. Cerca de dois anos após, o Decreto-Lei no 986/69 revogou o CBA, introduziu o conceito de padrão de identidade e qualidade e instituiu as normas básicas sobre alimentos (COSTA, 2004).

A legislação da década de 1970 conformou os fundamentos jurídicos de Vigilância Sanitária vigentes e abrangeu a criação da Secretaria Nacional de Vigilância Sanitária do Ministério da Saúde (SNVS/MS), através da Lei no 6.369/76. A falta de estrutura e a ausência de capacidade fiscalizadora suficiente fez com que esse modelo de vigilância adquirisse características marcadamente cartoriais, não sendo baseada na inspeção sanitária (LUCCHESE, 2006). 
A década de 1980 imprimiu suas marcas na história da Vigilância Sanitária. A estruturação de inúmeros órgãos estatais como o Conselho de Defesa do Consumidor, os PROCONs, as delegacias e comissões, o Instituto Brasileiro de Defesa do Consumidor (IDEC) e outros, forçaram o governo a pender em direção ao lado da balança onde está o cidadão. Com o surgimento da Nova República, em 1985, técnicos foram incorporados ao movimento pela reforma sanitária. Pela primeira vez, um grupo de sanitaristas assumiu o órgão nacional de Vigilância Sanitária compartilhando a sua ação com a dos profissionais das Secretarias Estaduais de Saúde, na busca da ruptura do modelo autoritário e centralizador da Vigilância e da construção de um novo modo de operar o setor (ROZENFELD, 2000).

Durante o período do Governo Collor de Mello, houve um retrocesso significativo na Vigilância Sanitária em função do Projeto Inovar e a reformulação da SNVS/MS. A busca da eficiência administrativa, por meio da simplificação da organização da SNVS/MS - que perdeu o 'nacional' do nome e se transformou em SVS/MS - sem considerar sua missão sanitária gerou retorno ágil às petições dos produtores, desconsiderando as análises técnico-científicas, sendo liberados, irregularmente, registros para uma enorme quantidade de produtos, gerando suspeitas de corrupção (COSTA, 2004; BUENO, 2005; LUCCHESE, 2006).

Com a promulgação da Constituição Federal de 1988, o Brasil passou a ter definição explícita de algumas responsabilidades - que até então não eram claras - como a promoção da saúde e as responsabilidades relacionadas à alimentação (BADARÓ et al., 2007).

A saúde é direito de todos e dever do Estado, garantindo mediante políticas sociais e econômicas que visem à redução do risco de doença e de outros agravos e ao acesso universal e igualitário às ações e serviços para sua promoção, proteção e recuperação (BRASIL, 1988). 
Seguindo os ditames da Constituição, que afirmou ser a 'saúde um direito de todos' e destacou as atribuições da Vigilância Sanitária como obrigação do Estado, produziu-se intensa atividade regulatória. Nesse contexto, a visão da Vigilância - como ação da cidadania - e sua fundamentação na epidemiologia e no enfoque de risco, tornaram-se mais consistentes. Adotou-se um contexto amplo e a Vigilância vinculou sua realização às políticas sociais e econômicas e ao acesso às ações e serviços destinados não somente à sua recuperação, mas também à sua promoção e proteção (DALLARI, 1995 apud BADARÓ et al., 2007).

A partir do surgimento da Lei ${ }^{\circ} 8.078 / 90$, o intitulado Código de Defesa do Consumidor, a legislação de proteção e defesa da saúde foi reforçada, reafirmando a responsabilidade do produtor pela qualidade do produto e do serviço, Ihe impondo atividades de informação ao consumidor (PEIXOTO et al., 2006). Esta legislação destina-se, também, a proteger interesses econômicos gerais, pois práticas abusivas contra o consumidor podem ameaçar a confiança nos produtos e nos fabricantes e levar prejuízos econômicos (BADARÓ et al., 2007). O Código de Defesa do Consumidor reconheceu e detalhou os direitos básicos do consumidor, criando normas específicas para a responsabilidade civil do fornecedor (LAZZARINI et al., 1997 apud BADARÓ et al., 2007). A qualidade higiênico-sanitária passou a receber atenção e ser fundamental para a sociedade. Essa transformação exigiu uma nova postura e modelo de atuação do serviço de vigilância em saúde (SOTO et al., 2006).

A Lei $n^{\circ}$ 8.080/90, a Lei Orgânica da Saúde, lançou os alicerces do Sistema Único de Saúde (SUS), enfocando a saúde não somente como direito de todos, mas também como dever do Estado, pautada nos princípios de universalização e operacionalização deste direito (BODSTEIN, 2000), inaugurou uma nova condição jurídico-formal para a Vigilância Sanitária; já 
que destaca a abrangência das ações de Vigilância, ao incluir, entre as competências do SUS, a vigilância de produtos, de serviços, dos ambientes e dos processos de trabalho, através de execução direta ou mediante a participação de outros setores (SILVA e COROA, 2005).

\footnotetext{
Entende-se por vigilância sanitária um conjunto de ações capazes de eliminar, diminuir ou prevenir riscos à saúde e de intervir nos problemas sanitários decorrentes do meio ambiente, da produção e circulação de bens e de prestação de serviços de interesse da saúde, abrangendo:

I - o controle de bens de consumo que, direta ou indiretamente, se relacionam com a saúde, compreendidas todas as etapas e processo da produção ao consumo; e

II - o controle da prestação de serviços que se relacionam direta ou indiretamente com a saúde (BRASIL, 1990b).
}

O "conjunto de ações" denota que a vigilância sanitária engloba um leque de atividades diversificadas, complexas, de natureza preventiva, que devem ser executadas de maneira articulada, ordenada e sempre voltadas para a racionalidade da eliminação, controle ou prevenção de riscos sanitários que possam vir provocar danos à saúde de consumidores de produtos e serviços de interesse da saúde, bem como dos ambientes (BASTOS, 2006).

Esta definição mostra a abrangência das ações da Vigilância Sanitária, a natureza essencialmente preventiva e sua "missão" de interferir na reprodução das condições econômico-sociais, ambientais e de vida, isto é, em ampla esfera dos fatores determinantes do processo saúde - doença qualidade de vida que se afiguram como riscos à saúde relacionados ao meio ambiente e à produção, circulação e consumo de bens e serviços (BADARÓ et al., 2007). 
O uso da expressão "eliminar, diminuir ou prevenir" demonstra forte conotação relacionada ao poder de polícia da vigilância sanitária ao estabelecer proibições e restrições. Entretanto, o fato de "intervir nos problemas" demonstra papel social e interventor que o Estado deve apresentar, sendo responsável pela proteção da saúde da população, à medida que desenvolve ações que controlem os riscos sanitários causadores de danos e agravos à saúde (SHUQAIR, 1996 apud BASTOS, 2006).

A Lei Orgânica da Saúde trouxe uma inovação ao incorporar o risco na definição da vigilância sanitária, sendo que na concepção de Costa (2004) a introdução de conceitos novos, como o risco, conferiu à vigilância sanitária um caráter mais abrangente e completo ao seu conjunto de ações, reforçando o papel de intervenção do Estado na determinação do processo saúde-doença.

No decorrer da década de noventa, a área de alimentos experimentou avanços muito significativos bem como a Vigilância Sanitária. Houve a definição das atribuições do Ministério da Agricultura e do Abastecimento e do Ministério da Saúde (ROZENFELD, 2000; BUENO, 2005) que passaram a ser os órgãos governamentais responsáveis pela legislação de alimentos (TABAI, 2002).

A necessidade de constante aperfeiçoamento das ações de controle sanitário na área de alimentos levou o Ministério da Saúde, dentro da sua competência, a elaborar a Portaria 1.428/93 que aprovou o Regulamento Técnico para Inspeção Sanitária de Alimentos, as Diretrizes para o Estabelecimento de Boas Práticas de Produção e Prestação de Serviços na área de Alimentos. Introduzindo, assim, nas normas o enfoque de 'risco epidemiológico', a ser incorporado ao planejamento das inspeções e ao 
estabelecimento de prioridades, por meio do Sistema de Avaliação dos Perigos e Pontos Críticos de Controle (APPCC) (RAMOS et al., 2005; BADARÓ et al., 2007), que é um instrumento que busca garantir a inocuidade dos alimentos através da identificação de operações onde um controle é essencial, sendo aplicado em todo o processo de produção permitindo ações corretivas antes que um alimento contaminado alcance o consumidor e considera os aspectos necessários para a aplicação de boas práticas de fabricação (BPF) (AKUTSU et al., 2005; BADARÓ et al., 2007). Como conseqüência, em 30 de julho de 1997, através da Portaria no 326, o Ministério da Saúde aprovou o regulamento técnico sobre as condições higiênico-sanitárias e de Boas Práticas de Fabricação, para estabelecimentos produtores / industrializadores de alimentos (SOUZA, 2006).

Os episódios ocorridos nos anos de 1996, 1997 e 1998, especialmente nas áreas de serviços e de medicamentos, fizeram com que a sociedade tomasse conhecimento do que já era explícito para os que trabalhavam com vigilância sanitária: a fragilidade. Neste momento, foi criada a Agência Nacional de Vigilância Sanitária (ANVISA) em substituição à SVS/MS (BUENO, 2005; LUCCHESE, 2006; BADARÓ et al., 2007).

A ANVISA foi criada em 26 de janeiro de 1999 através da Lei 9.782. É uma autarquia sob regime especial, ou seja, uma agência reguladora, caracterizada pela independência administrativa, estabilidade de seus dirigentes durante o período de mandato e autonomia financeira (ADDÔR, 2004). Esse modelo de descentralização proposto fortalece a Vigilância Sanitária (SIQUEIRA et al., 2006). Na estrutura da Administração Pública Federal, a agência está vinculada ao Ministério da Saúde e tem por finalidade institucional "promover a proteção à saúde da população por intermédio do controle sanitário da produção e da comercialização de produtos e serviços submetidos à vigilância sanitária, inclusive dos 
ambientes, dos processos, dos insumos e das tecnologias a eles relacionados, bem como o controle de portos, aeroportos e fronteiras" (ANVISA, 2006).

São bens, produtos e serviços submetidos ao controle e à fiscalização sanitária, segundo BADARÓ et al. (2007):

- os alimentos, inclusive bebidas, águas envasadas, seus insumos, suas embalagens, aditivos alimentares, limites de contaminantes orgânicos, resíduos de agrotóxicos e de medicamentos veterinários;

- as instalações físicas, equipamentos, tecnologias, ambientes e procedimentos envolvidos em todas as fases de seus processos de produção dos bens e produtos submetidos ao controle e fiscalização sanitária, incluindo a destinação dos respectivos resíduos.

Apesar da polêmica que cerca a constituição da ANVISA, no contexto da reforma do Estado, são inegáveis os avanços, principalmente se comparados à estrutura anterior, onde eram mínimas as possibilidades de controle gerencial dos escassos recursos e freqüentes injunções políticas levavam à descontinuidade político-administrativa e à rotatividade nos cargos (DE SETA e SILVA, 2006).

Desde a criação da ANVISA, a Vigilância Sanitária vem passando por mudanças em todo o país. Mudanças organizativas, nos processos de trabalho, para se adequar às inovações científicas (DE SETA e SILVA, 2006).

O momento atual é pródigo em transformações tecnológicas e, também, de caráter sanitário por multiplicarem-se as doenças por microrganismos emergentes ou reemergentes (PANETTA, 2004), 
justificando o objetivo da ANVISA de produzir e utilizar novos conhecimentos tecnológicos para apoiar suas ações (ANVISA, 2003).

De acordo com o Codex Alimentarius (2003) e a OMS (2002), o acesso a alimentos livres de contaminação e ideais para o consumo é um direito de todas as pessoas, portanto é uma atenção primária à saúde e uma constante preocupação de Saúde Pública (VELLO et al., 2005) por ser considerado o maior problema de saúde no mundo contemporâneo (TABAI, 2002).

As doenças veiculadas por alimentos são um grande problema de Saúde Pública em qualquer parte do mundo, especialmente, em países em desenvolvimento como o Brasil (LIMA e OLIVEIRA, 2005) e vêm aumentando independentemente dos avanços tecnológicos. Acredita-se que os problemas de toxinfecções alimentares ocasionados na população ocorrem devido, em parte, à falta de prioridade dos órgãos públicos em defesa da saúde (TABAI, 2002) e elas geralmente trazem conseqüências desagradáveis, resultam em freqüente abstinência ao trabalho e à escola, e podem ser fatais. É um problema grave e imediato para a saúde humana, além de provocar um grande impacto econômico no país (BELLARDE et al., 2005; LIMA e OLIVEIRA, 2005; GOTTARDI et al., 2006).

Anualmente, uma parcela da população, que supera o patamar de $30 \%$ em países industrializados, entre os quais se inclui o Brasil, é atingida por alguma doença veiculada por alimentos. É sabido que, devido à dificuldade de comprovação destas ocorrências em nosso país, os registros estatísticos dificilmente condizem com a realidade, mas segundo os dados do Centro Nacional de Epidemiologia do Ministério da Saúde, no ano de 2000 ocorreram mais de 7.000 casos de intoxicação por alimentos (TABAI, 2002). E, de acordo com dados do Centro de Vigilância Epidemiológica do 
Estado de São Paulo, os surtos de doenças transmitidas por água e alimentos notificados de janeiro a maio de 2003 no Estado chegou a cinqüenta. O número de casos foi de 769 chegando a dois óbitos (SÃO PAULO, 2003).

Os custos dessas doenças são igualmente alarmantes. Uma estimativa feita nos Estados Unidos avaliou um gasto anual de até 37,1 bilhões de dólares com despesas diretas e indiretas decorrentes dessas enfermidades, o que corresponde a 150 dólares por pessoa (SCHLUNDT, 2002). Estima-se, então, em 20 bilhões de dólares as despesas anuais com doenças ocasionadas pela ingestão de alimentos contaminados, no Brasil. Entretanto, é muito provável que os valores sejam maiores, já que essas doenças atingem com mais freqüência e intensidade as populações mais carentes, menos esclarecidas e, provavelmente, já debilitadas. No entanto, como a maioria dos casos de doenças de origem alimentar não é notificada, a verdadeira dimensão do problema é desconhecida. A ausência de dados confiáveis impede a compreensão de sua importância para a saúde pública e para o desenvolvimento de soluções (BADARÓ et al., 2007).

Silva Jr (2005) destacou como principais fatores relacionados à ocorrência de doenças de origem alimentar a má condição de higiene na manipulação dos alimentos, o uso incorreto do binômio tempo-temperatura, más condições de armazenamento e conservação dos alimentos e falta de adequação e conservação da estrutura física.

Segundo o International Comission for the Microbial Specification of Foods - ICMSF, citado por Massaguer (2006), os riscos associados aos alimentos podem ser classificados com base em sua magnitude: 
1 - ausência de risco direto à saúde, caso em que a contaminação ocorre por agentes saprófitos ou está associada à redução da vida de prateleira ou ao início de deterioração;

2 - risco reduzido para saúde, indireto, quando no alimento é detectada a presença de microrganismos indicadores;

3 - risco moderado à saúde, porém direto, de difusão limitada, quando os microrganismos presentes no alimento só causam doença quando ingeridos em altas concentrações ou em grande quantidade de suas toxinas. Os surtos são restritos aos indivíduos que ingeriram o produto;

4 - risco moderado à saúde, porém direto e de difusão extensiva, situação em que o agente microbiano se difunde através de contaminações ambientais e/ou cruzadas nas áreas de preparo de alimentos;

5 - risco severo e direto, caracterizado pelo fato de que o microrganismo contaminante (ou suas toxinas) tem alta capacidade de patogênese, mesmo em pequenas concentrações.

As rápidas mudanças sociais, tecnológicas e comportamentais sofridas pela sociedade brasileira, além do grande impulso da alimentação coletiva, que ocorreram ao longo dos anos, especialmente após a II Guerra Mundial, influenciaram novos hábitos sociais e a mudança no padrão de consumo alimentar constituindo-se em novos desafios (AKUTSU et al., 2005; CARVALHO e CARVALHO, 2006; LANZILLOTTI et al., 2006).

À medida que aumenta a renda per capita e o país se desenvolve, ocorrem mudanças nos hábitos alimentares (PINELLI e ARAÚJO, 2006). Estes vêm sofrendo alterações devidas, principalmente, à vida moderna, com suas exigências de longas jornadas de trabalho, a participação crescente das mulheres no mercado de trabalho, a diminuição no tamanho das famílias, o aumento de número de pessoas que moram sozinhas, as distâncias nas grandes cidades e os problemas de transporte. Esses fatores acarretam na diminuição do tempo disponível para a preparação de alimentos e/ou o seu consumo, levando as pessoas à necessidade de fazerem suas refeições fora de casa (DE DEUS et al., 2005; FATTORI et al., 2005; PANZA et al., 2006; PINELLI e ARAÚJO, 2006). A alimentação 
tradicional vem perdendo espaço para novas práticas alimentares (PIPITONE, 2005) e a preferência atual dos consumidores é por refeições mais convenientes no que se refere à facilidade, seja na sua aquisição e preparo, economizando tempo, seja no seu consumo fora do domicílio (DALLARI et al., 2000; DE DEUS et al., 2005; FATTORI et al., 2005), nas proximidades do local de trabalho (MORAES et al., 2005; SILVA et al., 2005).

Devido a esses fatores, a indústria de comida de rua tem se consolidado por satisfazer as necessidades - especialmente da população de baixa renda - de obtenção de alimentos rápidos, de baixo custo e em local próximo ao trabalho (LUCCA e TORRES, 2002) e, também, por ser uma estratégia de sobrevivência para grupos socialmente excluídos, principalmente nos países em desenvolvimento, representando a um só tempo, uma oportunidade de trabalho e renda e uma alternativa para atender necessidades alimentares de populações urbanas (CARDOSO et al., 2006). Ou seja, o comércio de alimentos de rua apresenta aspectos positivos devido a sua importância socioeconômica, cultural e nutricional; e negativas no tocante às questões higiênico-sanitárias (LUCCA e TORRES, 2002), representando uma ameaça à saúde do consumidor, devido a técnicas de higiene e manipulação de alimentos inadequadas (LUCCA e TORRES, 2002; CARDOSO et al., 2006; SIQUEIRA et al., 2006).

ARAÚJO apud AKUTSU et al. (2005) estimam que, no Brasil, a cada cinco refeições, uma é feita fora de casa, na Europa duas em cada seis e, nos EUA, uma refeição em cada duas. Esses dados indicam claramente que ainda pode haver um grande aumento e desenvolvimento dos estabelecimentos que produzem alimentos para consumo imediato em nosso país. 
A Vigilância Sanitária como órgão responsável pelas fiscalizações que objetivam a defesa e a proteção da saúde, individual ou coletiva, deve estar atenta não somente às mudanças de costume dos hábitos alimentares da população mas para os locais de maior consumação de alimentos (MORAES et al., 2005) e atentando, também, para os critérios preconizados para a estrutura dos locais onde são manipulados e vendidos esses alimentos bem como os critérios de tempo e temperatura.

O cenário de pouca concorrência, com o mercado regido pelo fornecedor, evoluiu para uma nova ordem econômica, desenvolvida tecnologicamente, aliada à tendência mundial de globalização dos mercados e a formação de blocos, como a União Européia e Mercosul, fazendo com que o governo brasileiro mudasse as políticas industriais de comércio exterior, induzindo as empresas a adotarem o caminho da competitividade, caracterizada pelo acirramento da concorrência e o mercado regido pelo cliente, obrigando a uma redução de custos (CARVALHO e CARVALHO, 2006; LANZILLOTTI et al., 2006), com um grande comprometimento da qualidade. Outro aspecto a ser considerado é o enfoque tradicional pelo qual atuam as vigilâncias brasileiras (SOTO et al., 2006). Nos EUA e em países europeus, foram implantados programas de controle, integrando informação e pesquisa. Assim, a produção científica se associa à notificação ativa, à educação sistemática da população e dos produtores (EDUARDO, 2000 apud SOTO et al., 2006).

Apesar de a Vigilância Sanitária constituir-se em assunto de grande relevância no âmbito da saúde pública, observa-se que são esparsas as pesquisas e publicações relacionadas ao tema (LEFÈVRE et al., 2005), bem como a mão-de-obra qualificada em seus serviços. COSTA (2005) afirma que, nesta área, o leque das profissões se abre para incorporar outros profissionais que não são originalmente da área da saúde, aumentando os 
desafios nos processos de formação e capacitação, sendo esse o obstáculo a ser superado dentro do processo de descentralização.

Para a Vigilância Sanitária poder cumprir com suas funções, mais especificamente em nível municipal, torna-se imprescindível que seus recursos humanos estejam capacitados, estruturados e adequados ao tipo de gestão municipal e ao universo de atuação local (SIMÕES, 2005), além do domínio da legislação vigente (SOTO et al., 2006). De acordo com FREO e REOLON (2006), a Organização Panamericana de Saúde considera que poucas regiões dispõem de um sistema adequado de Vigilância Sanitária de alimentos e que ainda são escassos os levantamentos nessa área. Face à demanda, métodos e técnicas de preservação dos alimentos e de proteção à saúde dos consumidores têm sido desenvolvidos por pesquisadores preocupados com a saúde coletiva (PANZA et al., 2006).

Nessa vertente, a Universidade de São Paulo ganha destaque por ser uma entidade reconhecida mundialmente pela qualidade de suas pesquisas, por disseminar e promover o conhecimento e o desenvolvimento científico (USP, 1988). E, com o objetivo de integrar a Universidade com os serviços de Vigilância Sanitária, a ANVISA criou os Centros Colaboradores em Vigilância Sanitária (CECOVISAs) que tem como missão a institucionalização acadêmica da Vigilância Sanitária. Essa parceria gera transferência tecnológica para a melhoria da atuação profissional, e reflexão transdisciplinar, sem ignorar a necessidade de ser mantida a independência e a crítica (CECOVISA 2006).

Desde que a Vigilância Sanitária assumiu um comportamento de forte orientação técnica, as atuações em parceria passaram a ser necessárias (SOTO et al., 2006). 
A integração entre a Universidade e a Vigilância Sanitária pode ser de grande valia, visto que as pesquisas científicas podem contribuir com a produção de conhecimento nessa área, para formação de profissionais melhor qualificados para essa atuação, e por outro lado a Universidade através dessa aproximação pode melhor orientar as suas atividades de ensino, pesquisa e extensão de forma a estar em melhor sintonia com as necessidades observadas pelos serviços de Vigilância Sanitária, e o que é mais importante com as necessidades sentidas pela população.

Tomando como referência essas características, na busca por identificar dentro da atuação Universidade de São Paulo, possíveis contribuições para a área de vigilância sanitária de alimentos, foi estruturado o presente estudo com o propósito de analisar, de forma crítica, o conhecimento científico produzido na área de alimentos, pelos programas de Pós-Graduação Strictu sensu. 


\section{JUSTIFICATIVA}

Consumir alimentos saudáveis e seguros do ponto de vista higiênico sanitário, apresentando um risco mínimo de doenças é direito inalienável de todo e qualquer cidadão. Entretanto, para que esse direito seja concretamente garantido, é necessário a atuação eficiente dos serviços oficiais de inspeção e vigilância, equipados e respaldados por legislação adequadamente atualizada (DESTRO, 1998).

A ocorrência de doenças de origem alimentar é um dos problemas que mais aflige os profissionais responsáveis pela qualidade dos alimentos comercializados. Cerca de 200 doenças podem ser veiculadas por alimentos contaminados por bactérias, fungos, vírus, parasitas, agentes químicos e substâncias tóxicas de origem animal e vegetal (GERMANO e GERMANO, 2003).

As pessoas são expostas aos riscos de forma irrestrita, já que se associam ao ato de ingestão alimentar. Essas doenças por sua distribuição universal e por constituírem um problema em ascensão, preocupam autoridades tanto em países desenvolvidos quanto em países em desenvolvimento (JAY, 2005).

A importância dessas doenças costuma ser subestimada pela maioria das pessoas, mesmo aquelas que têm certo grau de instrução. A falta de informação pode gerar falha na identificação de doenças ou levar a um falso diagnóstico. Além disso, se os consumidores não reconhecerem o risco pessoal, também não procuram modificar seus hábitos de manipulação e de consumo (FEIN et al., 1995 apud BADARÓ et al., 2007). 
Em países em desenvolvimento como o Brasil, a situação é ainda mais crítica, uma vez que a notificação de doenças transmitidas por alimentos é uma exceção comprometendo a avaliação de um problema que afeta toda sua população, porém afeta com mais intensidade as camadas mais carentes e desprotegidas da sociedade (LUCCA e TORRES, 2002).

Em nosso país, caracterizado por clima predominantemente subtropical e tropical, associado às condições sócio-econômicas, ao crescente aumento de alimentação fora do domicilio entre outros fatores, alertam para a necessidade de constante monitoramento das condições necessárias à garantia da segurança alimentar, tanto no que se refere ao acesso quanto à qualidade dos alimentos. Dentro desse contexto a preocupação com a ocorrência de toxinfecções alimentares deve sempre estar presente, devido à facilidade de multiplicação em nosso ambiente, de microrganismos patogênicos que possuem ampla disseminação, o que pode ser agravado pela deficiência de saneamento básico, informação e educação sanitária.

As doenças transmitidas por alimentos são, talvez, o problema de saúde pública mais difundido no mundo, porém despertam pouca atenção dos governos nacionais (DESTRO, 1998). Segundo o Programa de Segurança Alimentar da Organização Mundial de Saúde (OMS), milhares de pessoas em todo o mundo adoecem devido ao consumo de água ou alimentos contaminados (FAÇANHA et al., 2002), e a ocorrência destas doenças torna-se cada vez mais freqüente (STOLTE e TONDO, 2001).

Com o fenômeno da urbanização crescente, a inserção do Brasil em mercados globalizados e as mudanças no estilo de vida que isto implica, uma parcela cada vez maior da população vem se alimentando diariamente fora do domicílio. Sabe-se que surtos de toxinfecções alimentares ocorrem mais freqüentemente em refeições produzidas em grande escala por envolverem um maior número de procedimentos e pontos de perigo de 
contaminações que, por sua vez, expõem esses consumidores ao risco de contraírem doenças transmitidas por alimentos (DALLARI et al., 2000; SIMÕES, 2005).

Dessa forma, destaca-se a importância e a atuação dos serviços de Vigilância Sanitária na área de alimentos. Na prevenção de toxinfecções alimentares deve-se considerar como prioritária a informação e é nesse âmbito que as pesquisas científicas assumem o seu valor.

A Universidade de São Paulo tem, dentre as suas finalidades, a promoção e desenvolvimento do conhecimento através do ensino e da pesquisa, a formação de pessoas capacitadas e qualificadas para as atividades profissionais e, o principal, a extensão à sociedade dos frutos provenientes do ensino e da pesquisa (USP, 1988).

A integração entre a Universidade e a Vigilância Sanitária é cada vez mais necessária. Visto que a Vigilância Sanitária é um tema em constante expansão e a Universidade, para cumprir o seu compromisso social, deve sempre realizar atividades de ensino e pesquisa pautadas nas necessidades sentidas pela população a qual presta serviços.

Reconhecendo essa necessidade, os Centros Colaboradores em Vigilância Sanitária (CECOVISAs) foram criados pela ANVISA e são uma das estratégias que buscam estabelecer parcerias com instituições públicas de ensino e de fomento à pesquisa para a formação de recursos humanos no campo de vigilância sanitária, contribuir com o Sistema Nacional de Vigilância Sanitária e realizar pesquisas científicas (CECOVISA, 2006).

A criação da Secretaria Nacional de Vigilância Sanitária, o Seminário Nacional de Vigilância Sanitária, ocorrido em 1985 em Brasília, o advento do Código de Defesa do Consumidor, a Lei Orgânica de Saúde, a criação da ANVISA em 1999 e a Conferência Nacional temática realizada em 2001, 
representam o dinamismo que o campo da Vigilância Sanitária vivencia nas últimas décadas (LEFÈVRE et al., 2005).

Para avaliar as boas práticas de fabricação são necessários que se conheçam primeiramente as características do produto e o processo produtivo envolvido, de modo que os perigos potenciais e riscos de contaminações envolvidos possam ser avaliados (PAZ et al., 1999).

O trabalho de vigilância sanitária está sujeito a modificações, devido ao surgimento de novos produtos e serviços, que por sua vez podem representar novos riscos a serem controlados. Isto significa a necessidade da vigilância acompanhar o avanço tecnológico e as conseqüentes mudanças advindas do progresso científico (COSTA, 2001; LUCCHESE, 2001). Este aspecto também é fortalecido pelo processo de globalização dos mercados, cuja concorrência comercial e tecnológica intensificou e fragmentou o processo produtivo, ampliando a oferta e comercialização de mercadorias. Em conseqüência, novos instrumentos de trabalho podem ser necessários para a realização de atividades de vigilância sanitária (BASTOS, 2006).

A segurança alimentar é um desafio atual e visa à oferta de alimentos livres de agentes que podem pôr em risco a saúde do consumidor. Em razão da complexidade dos fatores, a questão deve ser analisada ao longo de toda cadeia alimentar. Assim, a fiscalização da qualidade dos alimentos deve ser feita não só no produto final, mas em todas as etapas da produção, desde o abate ou a colheita, passando pelo transporte, armazenamento e processamento, até a distribuição final ao consumidor (VALENTE e PASSOS, 2004).

Apesar de a Vigilância Sanitária constituir-se em assunto de alta relevância e importância no âmbito da saúde pública, observa-se que ainda são esparsas as pesquisas e publicações relacionadas ao tema. Embora, 
nos últimos anos, a Vigilância Sanitária tenha emergido como um setor importante e crucial nas políticas públicas para a promoção e proteção da vida (MARQUES, 2005).

A Universidade de São Paulo tem um destacado papel na produção de conhecimento, que ocorre através de pesquisas, muitas delas relacionadas a programas de Pós-Graduação Strictu sensu. Dentre os programas existentes, muitos vêm, ao longo dos anos, desenvolvendo pesquisas na área de alimentos. Considerando a relevância do conhecimento nessa área para atuação dos serviços de Vigilância Sanitária de Alimentos, o presente estudo procurou identificar dentre as dissertações e teses apresentadas em temas relacionados, possíveis contribuições para o conhecimento técnico e cientifico que possam direta ou indiretamente contribuir para melhor direcionar as ações desse campo de prática. 


\section{OBJETIVOS}

- Avaliar a contribuição do conhecimento oriundo de pesquisas científicas, de cursos de Pós-Graduação Strictu sensu da Universidade de São Paulo, com potencial de aplicação na área de Vigilância Sanitária de 1993 a 2007;

- Fornecer subsídios para o aprimoramento da integração entre a Universidade e os serviços de Vigilância Sanitária no país. 


\section{MÉTODOS}

De acordo com Almeida (1996), a monografia constitui um trabalho escrito, que tanto pode ser um trabalho original, e exaustivo, quanto pode se constituir de um trabalho de revisão e atualização sobre um tema específico, limitado no tempo e no espaço, abordando em profundidade o tema escolhido e de forma sistematizada.

A partir deste conceito, foi elaborada uma dissertação de mestrado, resultante de um estudo teórico original, limitado no tempo e no espaço, embasado na pesquisa e na análise crítica.

\subsection{Etapas da pesquisa científica}

De acordo com Minayo (1992) e Almeida (1996), seguiram-se as seguintes etapas para a abordagem do assunto:

\subsection{Delimitação do tema}

O tema escolhido foi a produção do conhecimento na área de Vigilância Sanitária de Alimentos analisando, de forma crítica, as teses e dissertações geradas através de pesquisas em cursos de Pós-graduação Strictu sensu, referentes ao tema, publicadas pela Universidade de São Paulo no período de 1993 a 2007. 


\subsection{Seleção das fontes bibliográficas}

A pesquisa bibliográfica foi realizada através do Sistema de Informações em Saúde Pública do Serviço de Biblioteca e Documentação da Faculdade de Saúde Pública na Universidade de São Paulo.

Foram selecionadas dissertações e teses publicadas pela Universidade de São Paulo, no período de 1993 a 2007, que no todo ou em parte desenvolveram pesquisas na área de alimentos, com potencial para subsidiar direta ou indiretamente a prática da vigilância sanitária de alimentos.

Para isso, foram consultadas:

\subsubsection{Base informatizada local}

Banco de dados DEDALUS que representa as coleções existentes no acervo das Bibliotecas da Universidade de São Paulo, com acesso via terminal ligado a REDEUSP, selecionando a opção "Teses USP".

Portal SABER que é o portal de publicação de teses e dissertações produzidas pela Universidade de São Paulo. 
A busca nessas bases de dados utilizou os seguintes descritores, em idioma português: "higiene dos alimentos", "higiene de alimentos", "vigilância sanitária de alimentos", "contaminação de alimentos", "microbiologia de alimentos", "serviços de alimentação", "inspeção de alimentos", "conservação de alimentos", "armazenagem de alimentos", "vida-deprateleira", "análise de alimentos", "alimentos (padrões)", "alimentos (legislação)", "alimentos (fiscalização)", "consumo de alimentos", "manipulação alimentos", "refeições - restaurantes', "indústria de alimentos", "conservação de alimentos (frio)", "qualidade alimentos", "rotulagem de alimentos", "alimentos congelados", "segurança alimentar", "transgênicos", "doenças alimentos", vigilância alimentos", "controle sanitário de alimentos", "fiscalização" e "legislação".

Os descritores utilizados obedeceram à forma a qual eles estão inseridos no DEDALUS.

O período da publicação para inclusão no estudo foi de janeiro de 1993 a dezembro de 2007, observando a data de defesa da tese ou dissertação.

Esse período foi escolhido por ser considerado significativo para um estudo qualitativo (Minayo, 1992) e, também, por causa das relevantes transformações sofridas pela Vigilância Sanitária nesse período, abrangendo a elaboração da Portaria 1.428/93 e a criação da Agência Nacional de Vigilância Sanitária.

A Portaria 1.428, de 26 de novembro de 1993, é considerada um divisor de águas na vigilância sanitária de alimentos por aprovar 0 Regulamento Técnico para Inspeção Sanitária de Alimentos, as Diretrizes 
para o Estabelecimento de Boas Práticas de Produção e de Prestação de Serviços na área de Alimentos e o Regulamento Técnico para o Estabelecimento de Padrão de Identidade e Qualidade para Serviços e Produtos na área de Alimentos; introduzindo o enfoque de risco epidemiológico a ser incorporado ao planejamento das inspeções e ao estabelecimento de prioridades através do APPCC. E a criação da Agência Nacional de Vigilância Sanitária é considerada um marco na história da Vigilância Sanitária do Brasil, sendo observada também, durante esse período, uma maior participação dos Estados e Municípios.

Primeiramente, foi realizada uma seleção inicial dos trabalhos pelos títulos. Quando a informação exata não constava neste, foi feita uma segunda seleção com a leitura exploratória dos resumos. As publicações julgadas de interesse foram, então, obtidas em Portable Document Format (PDF), quando não disponível nesse de forma eletrônica, foram obtidas através de busca direta no acervo bibliotecário da Universidade de São Paulo.

\subsubsection{Bases de dados nacionais e internacionais}

Para revisão de literatura e subsidiar a discussão, foram selecionadas, também, publicações científicas de acordo com o tema e relevância, através do:

MEDLINE (Medical Literature on-line) - Literatura mundial sobre ciências da saúde e afins desde 1966; reúne referências e resumos de 
artigos de cerca de 3.300 periódicos de âmbito internacional no campo das ciências de saúde e afins.

LILACS (Literatura Latino-Americana em Ciências da Saúde) que reúne referências de documentos da Literatura sobre Ciências da Saúde gerada na América Latina e o Caribe desde 1982.

SciELO (Scientific Electronic Library Online) - Biblioteca eletrônica que abrange uma vasta coleção selecionada de periódicos científicos brasileiros.

\subsubsection{Outras fontes}

O material bibliográfico foi pesquisado no acervo individual da biblioteca da Faculdade de Saúde Pública.

A fim de obter um maior suporte a análise e discussão das teses e dissertações, foram pesquisados dispositivos legais relacionados ao controle sanitário de alimentos, dando preferência às páginas virtuais oficiais dos órgãos fiscalizadores. Foi obtida, especialmente, a Legislação Federal via on-line através da página virtual da ANVISA e, quando necessário, as Legislações Estaduais e Municipais.

\subsection{Fichamento bibliográfico}

Todo material trabalhado recebeu uma ficha própria, onde as dissertações lidas foram resumidas, analisadas e destacadas informações 
relevantes e resultados obtidos pelo autor em seu trabalho, data de publicação e contexto da citação.

Após o fichamento, cada pesquisa foi identificada com um código alfanumérico composto pelos dois últimos dígitos de seu ano de publicação (de 93 a 07), inicial do programa de pós-graduação (mestrado $=\mathrm{M}$ ou doutorado = D) seguido de um número em ordem crescente para facilitar sua localização durante a análise dos dados.

\subsection{Compilação das referências bibliográficas}

As referências bibliográficas foram compiladas e organizadas de acordo com o Guia de Apresentação de Teses, publicado pela Faculdade de Saúde Pública da Universidade de São Paulo (FSP - USP 2006). 


\section{RESULTADOS E DISCUSSÃO}

\subsection{CARACTERIZAÇÃO DA AMOSTRA ESTUDADA}

Foram levantadas 402 dissertações e teses produzidas pela USP, entre os anos de 1993 e 2007. Destas, 65 pesquisas foram descartadas porque, através de uma leitura mais aprofundada, verificou-se que não se encaixavam no propósito deste estudo ou, no caso das teses mais antigas, não foram localizadas em sua biblioteca de origem.

Portanto, no total, foram analisadas 337 pesquisas neste estudo, sendo $253(75,07 \%)$ dissertações de mestrado e 84 (24,93\%) teses de doutorado.

De acordo com a FIGURA 1, observa-se um aumento significativo no número de pesquisas pertinentes à área de Vigilância Sanitária de Alimentos a partir do ano 2000. Esse fato pode ser relacionado à criação da ANVISA através da Lei 9.782, de 26 de janeiro de 1999, e também aos avanços científicos e tecnológicos vivenciados na última década. 
Figura 1 - Distribuição das teses e dissertações analisadas, de 1993 a 2007, por ano de publicação.

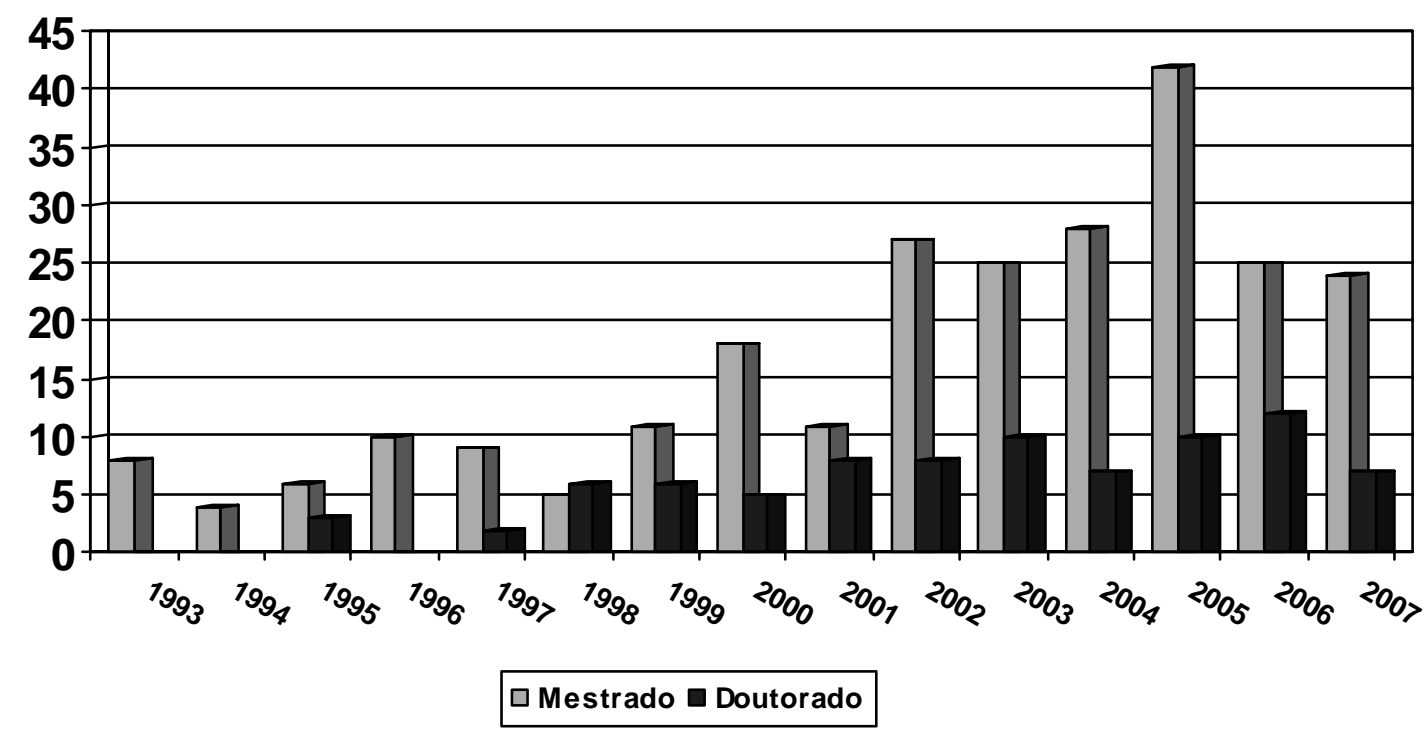

Foi analisado, também, o local de procedência dessas teses e dissertações, segundo sua unidade de ensino. De acordo com a TABELA 1, das 337 (100\%) pesquisas, 119 (32,10\%) procedem da Faculdade de Ciências Farmacêuticas - FCF, 98 (28,97\%) são oriundas da Escola Superior de Agricultura "Luiz de Queiroz" - ESALQ, 54 (19,31\%) foram produzidas pela Faculdade de Saúde Pública - FSP, 15 (6,81\%) procedem do Instituto de Química - IQ, 11 (3,69\%) são oriundas do Centro de Energia Nuclear na Agricultura - CENA e $40(10,79 \%)$ procedem de outras unidades de ensino da USP, como a Escola Politécnica (EP), Escola de Enfermagem de Ribeirão Preto (EERP), Instituto de Psicologia (IP), Faculdade de Medicina de Ribeirão Preto (FMRP), Faculdade de Ciências Farmacêuticas de Ribeirão Preto (FCFRP), Instituto de Ciências Biomédicas (ICB), Faculdade de Economia e Administração (FEA), Faculdade de Zootecnia e Engenharia de Alimentos (FZEA), Faculdade de Filosofia Letras e Ciências Humanas (FFLCH), Escola de Engenharia de São Carlos (EESC), Faculdade de Medicina (FM), Instituto de Pesquisas Energéticas e Nucleares (IPEN), Programa de Pós-Graduação em Ciência Ambiental (PROCAM), 
Escola de Enfermagem de Ribeirão Preto (EERP) e Interunidades em Ecologia de Agroecossistesmas (ECOAGROEC).

Tabela 1 - Distribuição das teses e dissertações analisadas, de 1993 a 2007, de acordo com a unidade de ensino.

\begin{tabular}{l|c|c}
\hline Unidade & $\mathbf{N}$ & $\mathbf{\%}$ \\
\hline FCF & 119 & 35,31 \\
ESALQ & 98 & 29,08 \\
FSP & 54 & 16,02 \\
IQ & 15 & 4,45 \\
CENA & 11 & 3,27 \\
Outras & 40 & 11,87 \\
\hline Total & $\mathbf{3 3 7}$ & $\mathbf{1 0 0}$ \\
\hline
\end{tabular}

Observou-se, também, o estado em que as pesquisas foram realizadas. Trezentas e trinta estudos $(97,92 \%)$ foram realizados dentro do estado de São Paulo, e 07 estudos (2,08\%) foram realizados em outros estados: 02 no Paraná, 02 no Espírito Santo, 01 no Rio Grande do Sul, 01 em Minas Gerais e 01 na Bahia. 


\subsection{DISTRIBUIÇÃO DAS TESES E DISSERTAÇÕES, DE 1993 A 2007, DE ACORDO COM O(S) OBJETIVO(S) DE PESQUISA}

Com o intuito de melhor análise, as teses e dissertações foram distribuídas em 20 categorias, de acordo com o(s) objetivo(s) proposto(s) pela pesquisa (TABELA 2): análise microbiológica de alimentos, que apresentou maior incidência (38,27\%); análise físico-química, nutricional e sensorial de alimentos (15,55\%); análise de meios de conservação de alimentos (10,37\%); análise da irradiação em alimentos (9,63\%); análise de resíduos em alimentos (8,64\%); Análise de Perigos e Pontos Críticos de Controle - APPCC e análise de procedimentos higiênicos (2,72\% cada); análise do processamento mínimo de alimentos e pesquisa do consumo alimentar (2,22\% cada); análise de alimentos transgênicos (1,98\%); análise da rotulagem de alimentos (1,23\%); investigação de surtos alimentares e análise da oxidação lipídica em alimentos ( $0,99 \%$ cada); análise do reuso da água, análise dos aspectos conceituais e operacionais da vigilância sanitária e comparação entre os efeitos dos cultivos orgânico e convencional $(0,49 \%$ cada); e caracterização dos profissionais que treinam manipuladores de alimentos, detecção de autenticidade ou adulteração de alimentos, avaliação de biodisponibilidade de nutriente sintético e natural e desenvolvimento de metodologia para determinação de ácidos graxos trans ( $0,25 \%$ cada). 
Tabela 2 - Distribuição das teses e dissertações, de 1993 a 2007, de acordo com o(s) objetivo(s) de pesquisa.

\begin{tabular}{l|c|c}
\hline Categorias & $\mathbf{N}$ & $\%$ \\
\hline Análise microbiológica de alimentos & 155 & 38,27 \\
Análise físico-química, nutricional e sensorial de alimentos & 63 & 15,55 \\
Análise de meios de conservação de alimentos & 42 & 10,37 \\
Análise da irradiação em alimentos & 39 & 9,63 \\
Análise de resíduos em alimentos & 35 & 8,64 \\
Análise de Perigos e Pontos Críticos de Controle - APPCC & 11 & 2,72 \\
Análise de procedimentos higiênicos & 11 & 2,72 \\
Análise do processamento mínimo de alimentos & 09 & 2,22 \\
Pesquisa de consumo alimentar & 09 & 2,22 \\
Análise de alimentos transgênicos & 08 & 1,98 \\
Análise da rotulagem de alimentos & 05 & 1,23 \\
Avaliação de surtos alimentares & 04 & 0,99 \\
Análise da oxidação lipídica em alimentos & 04 & 0,99 \\
Análise do reuso da água & 02 & 0,49 \\
Análise dos aspectos conceituais e operacionais da VISA & 02 & 0,49 \\
Comparação entre os efeitos dos cultivos orgânico e convencional & 02 & 0,49 \\
Caracterização dos profissionais que treinam manipuladores & 01 & 0,25 \\
Detecção de autenticidade ou adulteração de alimentos & 01 & 0,25 \\
Avaliação da biodisponibilidade de nutriente sintético e natural & 01 & 0,25 \\
Desenvolvimento de metodologia para determinar ácidos graxos trans & 01 & 0,25 \\
\hline Total & $\mathbf{4 0 5}$ & $\mathbf{1 0 0}$ \\
\hline & &
\end{tabular}

Como pôde ser observado na TABELA 2, todas as teses e dissertações analisadas neste estudo (100\%) abordaram assuntos contemporâneos. Os pesquisadores tiveram a preocupação e o interesse de desenvolver pesquisas voltadas à realidade vivida atualmente pela população brasileira, dando ênfase à evolução tecnológico-científica; assuntos estes de importância à Vigilância Sanitária de Alimentos. 


\subsubsection{Análise Microbiológica de Alimentos}

Como pode ser observado na TABELA 3, dos 155 (100\%) temas analisados, $80(51,62 \%)$ verificaram a ocorrência de microrganismos em alimentos, $27(17,42 \%)$ verificaram a resistência térmica de microrganismos, $21(13,55 \%)$ realizaram a caracterização fenotípica e genotípica de microrganismos, $11(7,10 \%)$ compararam a eficiência dos métodos moleculares em relação aos métodos microbiológicos clássicos, 09 (5,81\%) caracterizaram microrganismos, 03 (1,93\%) detectaram a capacidade enterotoxigênica de microrganismos, 03 (1,93\%) estudaram a descontaminação de alimentos inoculados e 01 (0,64\%) avaliou o desempenho de diversos meios de cultura.

Tabela 3 - Distribuição das teses e dissertações, de 1993 a 2007, de acordo com o tema "Análise Microbiológica de Alimentos".

\begin{tabular}{l|c|c}
\hline Sub-Categorias & N & \% \\
\hline Verificar ocorrência de microrganismos em alimentos & 71 & 45,81 \\
Verificar resistência térmica de microrganismos & 27 & 17,42 \\
Caracterização fenotípica e genotípica de microrganismos & 21 & 13,55 \\
Comparação entre microbiologia convencional e molecular & 11 & 7,10 \\
Caracterização de microrganismos & 09 & 5,81 \\
Detectar capacidade enterotoxigênica de microrganismos & 03 & 1,93 \\
Descontaminação de alimentos inoculados & 03 & 1,93 \\
Desempenho de meios de cultura & 01 & 0,64 \\
\hline Total & $\mathbf{1 5 5}$ & $\mathbf{1 0 0}$ \\
\hline
\end{tabular}

Entre os vários parâmetros que determinam a qualidade de um alimento, os mais importantes são aqueles que definem as suas características microbiológicas e foi esse o parâmetro mais pesquisado nas 
teses e dissertações analisadas nesse estudo. A avaliação da qualidade microbiológica de um produto fornece informações que permitam avalia-lo quanto ás condições de processamento, armazenamento e distribuição para o consumo, sua vida útil e quanto ao risco à saúde da população (FRANCO, 2002a).

TASSINARI (1995), em sua dissertação de mestrado (anexo 1 95M02), constatou que a porcentagem de amostras negativas para Salmonella typhimurium em alimentos aquecidos no forno de microondas convencional foi maior do que no forno computadorizado. Foi observado, também, que os efeitos de distribuição microbiana, por microondas estão fortemente relacionados ao binômio tempo-temperatura.

A eficácia da utilização de microondas para inativação dos microrganismos presentes no leite de vaca cru foi pesquisada por CRUZ (1996) em sua dissertação de mestrado (anexo 1 - 96M01). A autora constatou que o tratamento do leite de vaca cru ao forno de microondas caseiro por 10 minutos, é adequado para reduzir a população bacteriana total e coliformes fecais provocando, portanto, efeito semelhante aquele da pasteurização convencional do leite.

BERSOT (2000) (anexo 1 - 00M15) avaliou o comportamento de Listeria monocytogenes frente ao processamento térmico de mortadelas, comercializadas em São Paulo, em diferentes condições de estocagem e constatou que $26,7 \%$ das amostras analisadas foram positivas para Listeria monocytogenes. A cocção das mortadelas a $74^{\circ} \mathrm{C}$ reduziu os inóculos de Listeria monocytogenes independente da formulação do produto. Nas mortadelas fatiadas foi observado um aumento médio de 2,5 log do número mais provável (NMP) da bactéria durante estocagem do produto. $\mathrm{O}$ autor cita que Listeria monocytogenes é freqüente em mortadelas; e conclui que o tratamento térmico reduziu 3 ciclos logarítmicos do microrganismo, não se observando a presença durante estocagem por 30 dias e que mortadelas 
fatiadas e embaladas a vácuo representam risco à população susceptível devido a multiplicação de Listeria monocytogenes.

A ocorrência de Vibrio spp. em moluscos bivalves comestíveis comercializados entre 2000 e 2002 nos municípios da área de influência da Baía de Todos os Santos e Valença, no estado da Bahia, foi pesquisada por BARBONI (2003) (anexo 1 - 03D29). A autora constatou que há risco de se contrair gastroenterite tanto pelo consumo de moluscos bivalves crus, mal cozidos ou preparados em más condições de higiene, adquiridos nos municípios pertencentes à área de estudo.

NERO (2005) (anexo 1 - 05D42) verificou a ocorrência de Listeria monocytogenes e Salmonella spp. em leite cru produzido em quatro regiões leiteiras do Brasil e constatou que os resultados negativos dos testes não devem ser considerados perigos de significância em leite cru produzido nas regiões estudadas, mas sim, devem ser interpretados com cuidado, pois existem fatores que podem interferir no isolamento desses patógenos, especialmente em relação à Listeria monocytogenes.

Em sua dissertação de mestrado, OLIVEIRA (2005) (anexo 1 05M35) avaliou as condições microbiológicas da pasteurização em amostras de leite comercializadas no município de Piracicaba, no estado de São Paulo, e verificou que o leite tipo $C$ foi o que apresentou resultado mais satisfatório dentre as amostras, pois, ao contrário do que se esperava, nenhuma amostra apresentou níveis elevados de contaminação microbiana. $\mathrm{O}$ autor ressalta que os resultados observados podem ser indicativos de prováveis falhas no controle do binômio tempo e temperatura durante a pasteurização industrial, matéria-prima excessivamente contaminada, higienização e sanificação deficientes das linhas de produção ou uma possível contaminação pós-pasteurização. 
A análise de alimentos com o intuito de se verificar quais e quantos microrganismos estão presentes é fundamental para se conhecer as condições de higiene em que esse alimento foi preparado, os riscos que esse alimento pode oferecer à saúde do consumidor e se o alimento terá ou não a vida útil pretendida (FRANCO, 2002b) 
5.2.1.1 Microrganismos mais comumente pesquisados nas teses e dissertações

Os microrganismos mais comumente analisados pelos pósgraduandos em suas teses e dissertações, entre os anos de 1993 a 2007 foram (TABELA 4): Coliformes totais (Enterobacter $s p$, Klebsiella $s p$ ), que apresentou maior incidência (16,86\%); Salmonella spp. (15,68\%); Coliformes fecais (E. coli, E. coli 157:H7) (14,79\%); Staphylococcus aureus (14,20\%); Listeria spp. (6,80\%); Fungos (bolores e leveduras) (6,21\%); Aeróbios mesófilos (5,91\%); Bacillus cereus e Vibrio spp. (2,96\% cada); Micotoxinas, (2,07\%); Psicrotrófilos, (1,77\% cada); Clostridium perfringens, Aeróbios mesófilos facultativos e Pseudomonas spp., (1,48\% cada); Clostrídios sulfitoredutores e Aeromonas spp. (1,19\% cada); Bacteriocinas (0,89\%); Enterobacter sakazaki (0,59\% cada); e, Psicrófilos e Clostridium botulinum $(0,30 \%$ cada). 
Tabela 4 - Microrganismos alvos de pesquisa das teses e dissertações, de 1993 a 2007.

\begin{tabular}{l|c|c}
\hline Microrganismos pesquisados & $\mathbf{N}$ & $\%$ \\
\hline Coliformes totais & 57 & 17,01 \\
Salmonella spp. & 53 & 15,82 \\
Coliformes fecais (E. coli, E. coli O157:H7) & 50 & 14,93 \\
Staphylococcus aureus & 48 & 14,33 \\
Listeria spp & 23 & 6,87 \\
Fungos (bolores e leveduras) & 21 & 6,27 \\
Aeróbios mesófilos & 20 & 5,97 \\
Bacillus cereus & 10 & 2,99 \\
Vibrio spp & 10 & 2,99 \\
Micotoxinas & 07 & 2,09 \\
Psicrotrófilos & 06 & 1,79 \\
Clostridium perfringens & 05 & 1,49 \\
Aeróbios mesófilos & 05 & 1,49 \\
Pseudomonas spp & 05 & 1,49 \\
Clostrídios sulfito-redutores & 04 & 1,19 \\
Aeromonas spp & 04 & 1,19 \\
Bacteriocinas & 03 & 0,89 \\
Enterobacter sakazakii & 02 & 0,60 \\
Psicrófilos & 01 & 0,30 \\
Clostridium botulinum & 01 & 0,30 \\
\hline Total & 335 & $\mathbf{1 0 0}$ \\
\hline
\end{tabular}

Ao analisarmos a TABELA 4, observamos que a maior parte das teses e dissertações (61,53\%) realizou pesquisas de microrganismos indicadores de contaminação em alimentos e de microrganismos patogênicos, tais como: coliformes totais, coliformes fecais, Staphylococcus aureus e Salmonella spp. 
Microrganismos indicadores são grupos ou espécies de microrganismos que, quando presentes em um alimento, podem fornecer informações sobre a ocorrência de contaminação de origem fecal, sobre a provável presença de patógenos ou sobre a deterioração potencial do alimento, além de poderem indicar condições sanitárias inadequadas durante o processamento, produção ou armazenamento (LANDGRAF, 2002).

LANDGRAF (2002) ainda complementa sua colocação, comentando que, entre os critérios considerados na definição de um microrganismo ou grupo de microrganismos como indicadores, incluem: ser de fácil e rápida detecção; ser facilmente distinguível de outros microrganismos da microbiota do alimento; não deve estar presente como contaminante natural do alimento, pois assim sua detecção não indicará, necessariamente, a presença da matéria fecal ou dos patógenos, entre outras.

Alimento seguro é aquele que apresenta atributos de qualidade para consumo, sendo este livre de contaminantes. A análise microbiológica em alimentos pode ser realizada a fim de investigar a presença ou a ausência de microrganismos no produto analisado, para quantificação dos microrganismos presentes e para identificação e caracterização de diferentes espécies microbianas.

Inúmeros métodos laboratoriais de análise podem ser utilizados em cada uma dessas determinações. Atualmente, esses métodos são comumente divididos em métodos "convencionais" e métodos "rápidos" (FRANCO, 2002b). 
5.2.1.2 Métodos convencionais e métodos moleculares utilizados para pesquisa de microrganismos em alimentos

Das 144 teses e dissertações (100\%) classificadas na categoria "Análise microbiológica de alimentos", 99 (68,75\%) fizeram uso de métodos microbiológicos convencionais em suas pesquisas e 45 (31,25\%) estudos utilizaram métodos moleculares.

Na FIGURA 2 observa-se a inserção dos métodos moleculares com o decorrer dos anos, em comparação à utilização dos métodos microbiológicos convencionais.

Figura 2 - Distribuição das teses e dissertações analisadas de 1993 a 2007, de acordo com o método microbiológico utilizado.

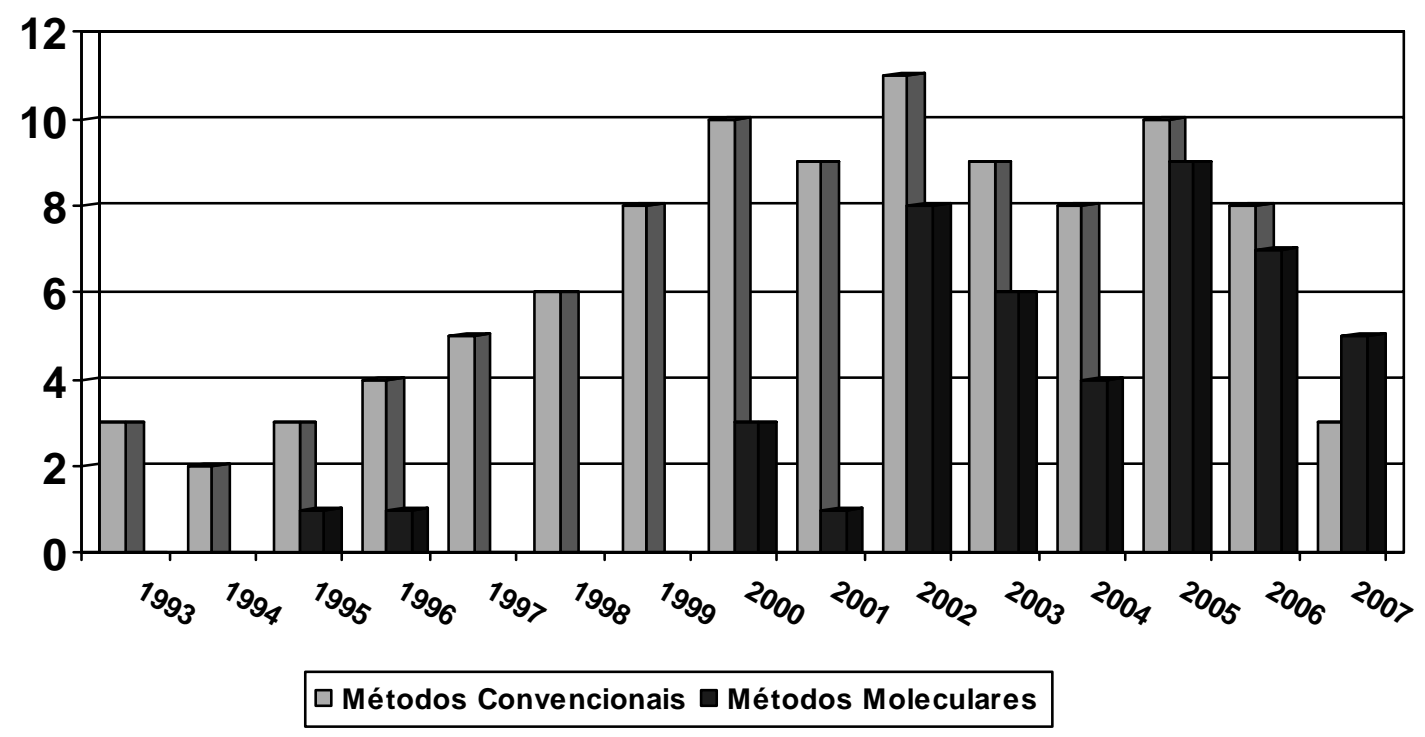

De acordo com os dados analisados, os métodos moleculares vêm sendo cada vez mais utilizados em pesquisas microbiológicas, especialmente a partir do ano de 2002, quando teve uma significativa 
ascensão. É observada, também, a partir de 2000, uma sensível oscilação na utilização de técnicas microbiológicas convencionais.

Os métodos clássicos de detecção de bactérias em alimentos envolvem etapas de pré-enriquecimento e enriquecimento seletivo, seguidos por testes de identificação morfológica, bioquímica e imunológica. Apesar de serem confiáveis, eficientes, bem estabelecidos e de requererem materiais de consumo mais baratos, tais procedimentos apresentam algumas desvantagens, como o trabalho intenso e a espera por vários dias pelos resultados (LANTZ et al., 2002 apud FREITAS et al., 2006; MALORNY et al., 2003 apud MARIN et al., 2006). Além disso, as propriedades fenotípicas pelas quais as bactérias são identificadas podem não ser sempre expressadas e quando são, podem ser difíceis de serem interpretadas e classificadas, além das células não poderem ser detectadas, pois estão em estado viável, porém não cultivável (MALORNY et al., 2003 apud MARIN et al., 2006).

Os métodos rápidos surgiram a partir da década de 70 , com conseqüência da necessidade de se abreviar o tempo necessário para a obtenção de resultados analíticos e melhorar a produtividade laboratorial (FRANCO, 2002b).

A introdução da reação em cadeia da polimerase (PCR) em diagnósticos microbiológicos tem sido estabelecida em pesquisas laboratoriais como uma valiosa alternativa para os métodos tradicionais (FREITAS et al., 2006; MARIN et al., 2006). Rapidez, bom limite de detecção, seletividade e potencial para otimização são as maiores vantagens desse método (FREITAS et al., 2006). Entretanto, existem algumas limitações a serem consideradas no uso da PCR, como a existência de técnicos ainda relutantes em utilizar esta nova técnica, em virtude do alto custo para o investimento tecnológico, a necessidade de aprovação oficial, regulamentos e instruções padronizadas, e a falta de uma legislação que 
padronize e valide este novo método, sendo este o principal impedimento para a utilização (MARLONY et al., 2003 apud FREITAS et al., 2006; MARIN et al., 2006).

A Reação em Cadeia da Polimerase ou, simplesmente, PCR (Polymerase Chain Reaction) permite a amplificação de uma região específica do DNA milhões de vezes. Isto é possível em virtude da utilização de dois iniciadores, ou primers, no qual um deles se "liga" a uma das fitas de DNA e o outro iniciador a outra fita. Esta amplificação se faz no equipamento denominado termociclador, onde vários ciclos se sucedem (normalmente de 25 a 45 ciclos). Cada ciclo corresponde a: temperatura de desnaturação (94 $\left.-95^{\circ} \mathrm{C}\right)$ do DNA molde, temperatura de anelamento $\left(45-65^{\circ} \mathrm{C}\right)$ dos primers e a uma temperatura de extensão $\left(72^{\circ} \mathrm{C}\right)$ através da utilização de uma polimerase resistente a esta temperatura. O DNA amplificado pode ser visualizado em gel de agarose sob luz UV, após ser corado com brometo de etídeo (MARIN et al., 2006).

Um método baseado em PCR carreia um risco mínimo de contaminação, devido às práticas como o uso de áreas de trabalho separadas, a diminuição do número de etapas com pipetas e o uso de ponteiras com filtros devem ser adotadas (FREITAS et al., 2006).

BELOTI (2000) (anexo 1 -00M01), em sua dissertação de mestrado, recomenda os métodos moleculares para a análise microbiológica do leite. De acordo com a autora, os métodos tradicionais de enumeração de microrganismos são lentos, laboriosos e requerem grande quantidade de material, sendo incompatíveis com a perecibilidade do leite.

Segundo FELDSINE et al. (2002), a validação de um método alternativo é a demonstração de que adequada confiança é conseguida quando os resultados obtidos pelo método alternativo são comparados 
àqueles obtidos usando o método de referência, por meio de critérios estatísticos contidos no protocolo de validação aprovado.

Em suas dissertações de mestrado, CAMPREGHER (2000) (anexo 1 - 00M20) e TAVOLARO (2000) (anexo 1 - 00M21), compararam a eficiência dos métodos moleculares perante os métodos da microbiologia convencional. Ambos citam que os métodos convencionais não devem ser descartados, mas sim, servir como complemento aos métodos moleculares.

ROJAS (2007) (anexo 1 - 07M32), em sua dissertação de mestrado, caracterizou, por meio de métodos moleculares, cepas ambientais de Vibrio parahaemolyticus. A autora concluiu que os métodos moleculares empregados no estudo foram uma excelente metodologia para identificação, caracterização dos fatores de virulência e tipagem molecular, demonstrando no seu conjunto, potencial de aplicação na vigilância em saúde.

Os métodos alternativos qualitativos podem ser utilizados como uma poderosa ferramenta na detecção de microrganismos patogênicos em alimentos. Porém, FREITAS et al. (2006) e MARIN et al. (2006) recomendam a padronização de protocolos e de validação internacional. Os autores alegam que, após anos da introdução da PCR, a sua aplicação na detecção de patógenos alimentares deverá ser ainda mais acelerada por intermédio dessa padronização; já que este processo, que envolve várias fases de comparações experimentais e de elaboração de guias, é dinâmico, sendo um contínuo desenvolvimento.

A implantação de técnicas de análise microbiológica mais rápidas e eficazes na detecção de microrganismos que representem risco imediato de doenças transmitidas por alimentos é fundamental para a produção de novos conhecimentos técnicos que viabilizem uma ação mais eficiente por parte da Vigilância Sanitária. 
5.2.1.3 Alimentos mais comumente pesquisados nas teses e dissertações

Os alimentos mais comumente analisados pelos pós-graduandos em suas teses e dissertações, entre os anos de 1993 a 2007 foram (TABELA 5): hortifruti in natura (17,12\%); leite de vaca (14,00\%); pescado (12,84\%); carne de boi e derivados (11,28\%); hortifruti minimamente processados $(9,73 \%)$; carne de frango e derivados (5,45\%); carne de porco e derivados (4,28\%); alimentos embutidos (3,89\%); refeições prontas para consumo $(3,11 \%)$; suco de frutas industrializado, farinha e massas (1,94\% cada); ovos de galinha (1,56\%); leite de búfala, amendoim e soja transgênica $(1,17 \%$ cada); leite materno, milho, sementes de linhaça, pães e hot-dog $(0,78 \%$ cada); e gelo, pimenta preta, geléia real, castanha-do-pará, margarina / cremes vegetais, palmito, cogumelos, café solúvel e mel ( $0,39 \%$ cada). 
Tabela 5 - Alimentos mais comumente analisados nas dissertações e teses realizadas entre os anos de 1993 a 2007, na Universidade de São Paulo.

\begin{tabular}{|c|c|c|}
\hline Categorias & $\mathbf{N}$ & $\%$ \\
\hline Hortifruti in natura & 44 & 17,12 \\
\hline Leite de vaca & 36 & 14,00 \\
\hline Pescado & 33 & 12,84 \\
\hline Carne de boi e derivados & 29 & 11,28 \\
\hline Hortifruti minimamente processados & 25 & 9,73 \\
\hline Carne de frango e derivados & 14 & 5,45 \\
\hline Carne de porco e derivados & 11 & 4,28 \\
\hline Alimentos embutidos & 10 & 3,89 \\
\hline Refeições prontas para consumo & 08 & 3,11 \\
\hline Suco de frutas industrializado & 05 & 1,94 \\
\hline Farinha & 05 & 1,94 \\
\hline Massas & 05 & 1,94 \\
\hline Ovos & 04 & 1,56 \\
\hline Leite de búfala & 03 & 1,17 \\
\hline Amendoim & 03 & 1,17 \\
\hline Soja transgênica & 03 & 1,17 \\
\hline Leite materno & 02 & 0,78 \\
\hline Milho & 02 & 0,78 \\
\hline Sementes de linhaça & 02 & 0,78 \\
\hline Pães & 02 & 0,78 \\
\hline Hot-dog & 02 & 0,78 \\
\hline Gelo & 01 & 0,39 \\
\hline Pimenta preta & 01 & 0,39 \\
\hline Geléia real & 01 & 0,39 \\
\hline Castanha-do-pará & 01 & 0,39 \\
\hline Margarina / cremes vegetais & 01 & 0,39 \\
\hline Palmito & 01 & 0,39 \\
\hline Cogumelos & 01 & 0,39 \\
\hline Café solúvel & 01 & 0,39 \\
\hline Mel & 01 & 0,39 \\
\hline Total & 257 & 100 \\
\hline
\end{tabular}


Os alimentos analisados refletem a sua procura pelos consumidores e, também, o fato de serem considerados potencialmente perigosos à saúde humana. Sendo que, os alimentos potencialmente perigosos são aqueles que por sua natureza, ou seja, composição, $\mathrm{pH}$, atividade água, favorecem a multiplicação dos microrganismos patogênicos (MARCHIONI e ZACARELLI, 1999; LANDGRAF, 2002; SILVA Jr., 2005).

Os vegetais possuem $\mathrm{pH}$ variando entre 5 a 7 que, aliado à umidade presente, possibilita o crescimento de grande número de microrganismos. A microbiota inicial dos vegetais provém do solo, água, ar, insetos e animais, sendo diretamente influenciada pela estrutura da planta e pelo homem, com sua tecnologia de cultivo, através da prática de irrigação de hortas com água contaminada por matéria fecal ou mesmo adubada com dejetos humanos, transporte e armazenamento (SIQUEIRA et al., 1997; TAKAYANAGUI, 2001; BALIONI et al., 2003). Além disso, é sabido que um grande número de enfermidades entéricas são veiculadas através de hortaliças contaminadas, destacando-se entre os agentes etiológicos os helmintos e os protozoários (SIQUEIRA et al., 1997; NASCIMENTO e MARQUES, 1998; TAKAYANAGUI, 2001; BALIONI et al., 2003; PAULA et al., 2003).

Observou-se, também, um número considerável de análises em alimentos cárneos, alimentos minimamente processados, alimentos embutidos e alimentos industrializados, como o suco de frutas industrializado, farinha e massas.

Esses dados também podem ser um bom indicativo de mudança nos padrões e consumo alimentar nos domicílios brasileiros, mudança essa que pode afetar significativamente o padrão nutricional e, consequentemente, a saúde e a qualidade de vida das pessoas. Entender melhor qual o nível de influência dos fatores socioeconômicos e demográficos associados a essa mudança no consumo alimentar é muito importante para a formulação de 
políticas públicas relacionadas à alimentação, saúde, qualidade de vida e, em suma, ao desenvolvimento econômico do país (SCHLINDWEIN, 2006a).

Na TABELA 5, também é observado um baixo número de análises em ovos e em óleos e gorduras vegetais. Segundo MONTEIRO et al. (2000), houve uma diminuição no consumo destes alimentos que, possivelmente, está atribuída a uma atitude consciente da população das áreas mais desenvolvidas do país em prol de uma dieta mais saudável.

FUNG (2001) realizou um estudo sobre padrões alimentares e demonstrou que o consumo habitual da dieta chamada "ocidental", caracterizada por uma alta ingestão de carnes vermelhas, produtos lácteos integrais, bebidas adocicadas, e sobremesas, está diretamente relacionado ao risco de desenvolver obesidade, doenças cardiovasculares e diabetes.

Também se pode salientar que este padrão alimentar ocidentalizado, com uma dieta rica em gorduras e com conservantes químicos, favorece o desenvolvimento da hipertensão arterial, pois a maioria destes alimentos é rica em sódio, influenciados pelo estilo de vida agitado, no qual as pessoas têm pouco tempo para preparar e realizar suas refeições, sem contar na questão de status que estes alimentos impõem na sociedade moderna (TARDIDO e FALCÃO, 2006).

\footnotetext{
A situação alimentar e nutricional da população brasileira está passando por uma transição epidemiológica, o que antes os problemas se concentravam nas carências nutricionais, atualmente convivem com patologias crônicas não transmissíveis provenientes de excessos e/ou erros alimentares (...) (RAYMUNDO e PEREIRA, 2002).
}

Nas últimas décadas, o ritmo acelerado de vida, a globalização e a influência da publicidade, contribuíram para a mudança no padrão alimentar. Dessa forma, os brasileiros foram substituindo os alimentos ricos em fibras pelos industrializados, refinados, ricos em gorduras e carboidratos simples (MARQUES e TUMA, 2001). Especificamente no Brasil, tem-se observado 
importantes mudanças na composição das famílias, na participação da mulher no mercado de trabalho e na urbanização, entre outros (SCHLINDWEIN, 2006a). Como conseqüência desses hábitos alimentares inadequados "impostos" pela modernidade, cresceu os índices de obesidade, diabetes, doenças cardiovasculares e outras doenças crônicas não transmissíveis.

A alimentação pode refletir o equilíbrio psicossomático do indivíduo, pois é parte integrante da saúde física e mental (PASTORE, 1998). E tanto o sobrepeso como a obesidade pode ser um desencadeador de diferentes patologias degenerativas que podem ser evitadas ou mesmo controladas com um acompanhamento nutricional adequado (RAYMUNDO e PEREIRA, 2002).

POSPISSIL (2002) comenta que:

O êxito da vida depende da saúde, sendo esta depende da alimentação do indivíduo. Sem uma alimentação correta, é impossível a conservação de um bom estado de saúde. Grande parte das doenças que afligem o homem hoje, tem raízes na alimentação errônea.

Um serviço de alimentação tem a obrigação de oferecer alimentos saborosos e com condições higiênico-sanitárias satisfatórias, proporcionando uma refeição saudável a quem se alimenta (GUIMARÃES, 2001); já que, ao se alimentar, todos buscam a satisfação e o prazer, sendo inquestionável a segurança do alimento ingerido (FIGUEIREDO, 2001).

Mudanças ocorridas no cenário mundial nas últimas décadas trouxeram consigo diversas alterações nos perfis socioeconômico, demográfico, epidemiológico e nutricional. Tais alterações diferem entre os países e os atingem de forma diferenciada. Além disso, a grande heterogeneidade existente entre os habitantes de um mesmo país determina vulnerabilidades marcadamente distintas, à ocorrência de distúrbios e carências nutricionais. No Brasil - país de dimensões continentais - as 
grandes diferenças na distribuição de renda, acesso à cultura e saúde, há muito discutidas, possibilitam a coexistência de estados nutricionais diametralmente opostos como a desnutrição e a obesidade (MONDINI e MONTEIRO, 2001). Contribuindo para solidificação do conceito de transição nutricional identificado por Monteiro et al., (2000) e reafirmado por diversos autores nacionais ao traçarem o perfil nutricional de diferentes grupos populacionais no país com o passar dos anos (GIGANTE et al., 1997; SAWAYA, 1998; SICHIERI et al., 1998; MONTEIRO et al., 2000; RIBEIRO, 2005; TARDIDO e FALCÃO, 2006).

Mundialmente, a ênfase do processo de prestação de serviços se desloca do eixo "recuperar a saúde do indivíduo doente" para: "prevenir riscos e agravos" e "promover a saúde das pessoas e dos grupos populacionais", o que implica tomar como objeto os problemas de saúde e seus determinantes, organizando a atenção de modo a incluir não apenas as ações e serviços que incidem sobre os "efeitos" dos problemas (doença, incapacidade e morte), mas, sobretudo, as ações e serviços que incidem sobre as "causas" (condições de vida, trabalho e lazer), ou seja, no modo de vida das pessoas e dos diversos grupos sociais (TEIXEIRA et al., 1998 apud TEIXEIRA, 2002).

Os hábitos alimentares constituem um aspecto muito importante do comportamento humano e a sua mudança é um processo lento e difícil. Porém, a dimensão dos problemas que podem ser ocasionados à saúde da população através dos maus hábitos alimentares não pode passar despercebido pelos serviços de Vigilância Sanitária, ressaltando a necessidade e a importância de programas de educação nutricional contínuos, que acompanhem o indivíduo durante todo o ciclo de vida, considerando que intervenções pontuais geralmente não conduzem à imprescindível mudança de hábitos construídos ao longo da existência, tão necessária à melhoria da qualidade de vida. 
5.2.1.4 Alimentos analisados em teses e dissertações, que apresentaram algum nível de contaminação microbiológica

Dentre os alimentos analisados em dissertações e teses, que apresentaram algum nível de contaminação microbiológica, entre os anos de 1993 e 2007, foram os alimentos protéicos.

Este tipo de alimento se caracteriza por oferecer condições ideais para o crescimento e a multiplicação microbiana, tais como: atividade água, nutrientes como a proteína e a gordura, $\mathrm{pH}$ adequado, além de vitaminas e sais minerais.

Levando em consideração a importância que os alimentos protéicos assumem na alimentação humana e o seu envolvimento em surtos alimentares, justifica-se a relevância e a necessidade desses dados microbiológicos. 
Tabela 6 - Análises microbiológicas, realizadas em produtos lácteos, de acordo com dados obtidos de dissertações e teses realizadas na Universidade de São Paulo, publicadas entre 1993 e 2007.

\begin{tabular}{|c|c|c|c|c|}
\hline Alimento & $\begin{array}{l}\text { Microrganismos e/ou } \\
\text { indicadores de } \\
\text { contaminação }\end{array}$ & $\begin{array}{c}\text { Número de amostras } \\
\text { analisadas por } \\
\text { microrganismo elou } \\
\text { indicador de contaminação }\end{array}$ & $\begin{array}{c}\text { Número de } \\
\text { amostras } \\
\text { contaminadas }\end{array}$ & $\%$ \\
\hline $\begin{array}{l}\text { Leite } \\
\text { Cru } \\
(n=268) *\end{array}$ & $\begin{array}{l}\text { Coliformes totais } \\
\text { Coliformes fecais } \\
\text { Salmonella spp. } \\
\text { S. aureus } \\
\text { L. monocytogenes }\end{array}$ & $\begin{array}{c}39 \\
39 \\
249 \\
39 \\
210\end{array}$ & $\begin{array}{c}20 \\
14 \\
0 \\
23 \\
0\end{array}$ & $\begin{array}{c}51,28 \\
35,90 \\
0 \\
58,97 \\
0\end{array}$ \\
\hline $\begin{array}{l}\text { Leite } \\
\text { Pasteurizado } \\
\text { Tipo A } \\
(\mathrm{n}=34)^{*}\end{array}$ & $\begin{array}{l}\text { Coliformes totais } \\
\text { Coliformes fecais } \\
\text { Salmonella spp. } \\
\text { S. coagulase positiva } \\
\text { Aeróbios mesófilos } \\
\text { Termófilos } \\
\text { Psicrófilos }\end{array}$ & $\begin{array}{l}34 \\
34 \\
10 \\
10 \\
34 \\
10 \\
10\end{array}$ & $\begin{array}{c}14 \\
06 \\
0 \\
0 \\
21 \\
0 \\
0\end{array}$ & $\begin{array}{c}41,18 \\
17,65 \\
0 \\
0 \\
61,76 \\
0 \\
0\end{array}$ \\
\hline $\begin{array}{l}\text { Leite } \\
\text { Pasteurizado } \\
\text { Tipo B } \\
(\mathrm{n}=46)^{*}\end{array}$ & $\begin{array}{c}\text { Coliformes totais } \\
\text { Coliformes fecais } \\
\text { Salmonella spp. } \\
\text { S. coagulase positiva } \\
\text { Aeróbios mesófilos } \\
\text { Termófilos } \\
\text { Psicrófilos }\end{array}$ & $\begin{array}{l}46 \\
46 \\
10 \\
10 \\
46 \\
10 \\
10 \\
\end{array}$ & $\begin{array}{c}29 \\
07 \\
0 \\
0 \\
21 \\
0 \\
0\end{array}$ & $\begin{array}{c}63,04 \\
15,22 \\
0 \\
0 \\
45,65 \\
0 \\
0 \\
\end{array}$ \\
\hline $\begin{array}{l}\text { Leite } \\
\text { Pasteurizado } \\
\text { Tipo C } \\
(\mathrm{n}=120)^{*}\end{array}$ & $\begin{array}{c}\text { Coliformes totais } \\
\text { Coliformes fecais } \\
\text { Salmonella spp. } \\
\text { S. aureus } \\
\text { Aeróbios mesófilos } \\
\text { Termófilos } \\
\text { Psicrófilos }\end{array}$ & $\begin{array}{c}101 \\
101 \\
53 \\
53 \\
48 \\
10 \\
10\end{array}$ & $\begin{array}{c}42 \\
21 \\
0 \\
01 \\
16 \\
0 \\
0\end{array}$ & $\begin{array}{c}63,04 \\
15,22 \\
0 \\
1,88 \\
33,33 \\
0 \\
0\end{array}$ \\
\hline $\begin{array}{l}\text { Leite } \\
\text { Materno } \\
(n=147) *\end{array}$ & $\begin{array}{c}\text { Coliformes totais } \\
\text { Coliformes fecais } \\
\text { Salmonella spp. } \\
\text { S. aureus } \\
\text { Aeróbios mesófilos } \\
\text { Bolores e leveduras } \\
\text { Bacillus cereus } \\
\text { Pseudomonas aeruginosa }\end{array}$ & $\begin{array}{c}147 \\
87 \\
87 \\
147 \\
147 \\
87 \\
87 \\
87\end{array}$ & $\begin{array}{c}68 \\
0 \\
0 \\
39 \\
87 \\
0 \\
12 \\
0\end{array}$ & $\begin{array}{c}46,26 \\
0 \\
0 \\
26,53 \\
59,18 \\
0 \\
13,79 \\
0\end{array}$ \\
\hline $\begin{array}{l}\text { Queijo minas } \\
\text { frescal } \\
(n=79) *\end{array}$ & $\begin{array}{l}\text { Coliformes totais } \\
\text { Coliformes fecais } \\
\text { Salmonella spp. } \\
\text { S. aureus } \\
\text { Pseudomonas spp. }\end{array}$ & $\begin{array}{l}79 \\
79 \\
19 \\
78 \\
19\end{array}$ & $\begin{array}{c}22 \\
17 \\
0 \\
20 \\
03\end{array}$ & $\begin{array}{c}27,85 \\
21,52 \\
0 \\
25,64 \\
15,79\end{array}$ \\
\hline $\begin{array}{l}\text { Leite cru de } \\
\text { búfala } \\
(n=12)\end{array}$ & $\begin{array}{l}\text { Coliformes totais } \\
\text { Coliformes fecais } \\
\text { Salmonella spp. } \\
\text { S. aureus } \\
\text { L. monocytogenes }\end{array}$ & $\begin{array}{l}12 \\
12 \\
12 \\
12 \\
12\end{array}$ & $\begin{array}{c}06 \\
02 \\
0 \\
03 \\
0\end{array}$ & $\begin{array}{c}50,00 \\
16,67 \\
0 \\
25,00 \\
0\end{array}$ \\
\hline $\begin{array}{c}\text { Sorvete de } \\
\text { massa } \\
(n=36)\end{array}$ & $\begin{array}{l}\text { Coliformes totais } \\
\text { Coliformes fecais } \\
\text { Salmonella spp. } \\
\text { S. coagulase positiva }\end{array}$ & $\begin{array}{l}36 \\
36 \\
36 \\
36\end{array}$ & $\begin{array}{c}09 \\
07 \\
0 \\
02\end{array}$ & $\begin{array}{c}25,00 \\
19,44 \\
0 \\
5,55\end{array}$ \\
\hline
\end{tabular}

${ }^{*} \mathrm{n}=$ total de amostras pesquisadas. (Obs.: nem todas as análises foram realizadas para todas as amostras). 
$\mathrm{Na}$ TABELA 6, podemos observar os dados de análises microbiológicas realizadas em produtos lácteos, que englobou amostras de leite cru, leite pasteurizado tipo A, leite pasteurizado tipo B, leite pasteurizado tipo $\mathrm{C}$, leite materno proveniente de bancos de leite humano, queijo minas frescal, leite cru de búfala e sorvete de massa.

O leite, se cuidadosamente tirado do animal saudável, terá níveis muito baixos de contaminantes bacterianos. Entretanto, na prática, ele rapidamente adquire microrganismos do animal, de seu meio ambiente imediato e do equipamento (ADAM e MATARJEMY, 2002).

A contaminação observada no leite cru é um dado importante. Pois, o Brasil tem uma grande produção leiteira e, embora, seu comércio seja ilegal, através da existência de legislação específica, como a Lei $n^{\circ}$. 1.283 , de 18/12/1950 e o Decreto no. 30.691, de 29/03/1952, o leite cru ainda é consumido por uma parcela da população, principalmente nas regiões rurais.

Foram observadas contagens elevadas de S. aureus $(58,97 \%)$, coliformes totais $(51,28 \%)$ e coliformes fecais $(35,90 \%)$ nas amostras provenientes de leite cru. Esses dados, de certa forma, são esperados, pois, além de não sofrer qualquer tipo de tratamento térmico, este tipo de alimento é mantido à temperatura ambiente por um longo período de tempo, desde a sua obtenção até a chegada ao domicílio do consumidor (BADINI et al., 1996).

OLIVEIRA (2005) (anexo 1 - 05M35) analisou as condições microbiológicas do leite cru comercializado na cidade de Piracicaba, SP, em sua dissertação de mestrado. O autor encontrou valores elevados para todas as análises microbiológicas realizadas: enumeração de bactérias aeróbias, mesófilas, termófilas e psicrotróficas, Staphylococcus coagulase positiva, determinação do número mais provável (NMP) de coliformes totais e fecais; com exceção da pesquisa de Salmonella spp. 
Em sua tese de doutorado, NERO (2005) (anexo 1 - 05D42) estudou a ocorrência de Listeria monocytogenes e Salmonela spp. em leite cru produzido em quatro importantes regiões produtoras de leite do Brasil, fazendo uma correlação com os níveis de contaminação com outros microrganismos indicadores de qualidade do produto (bactérias aeróbias mesófilas totais, coliformes totais e Escherichia coli).

BADINI et al. (1996) observaram, na época em que o estudo foi realizado, a inexistência de qualquer tipo de fiscalização e/ou controle higiênico-sanitário dos animais que estão envolvidos com a produção do leite cru, assim como do processo de obtenção, transporte e comercialização, e que tais dados constituem-se em motivo de preocupação, principalmente em função do risco representado pelo consumo deste produto sem que tenha sido previamente submetido à fervura. Nos tempos atuais, a preocupação com essa prática ainda persiste em populações situadas em regiões rurais, até mesmo por razões culturais e, também, econômicas no que diz respeito a sobrevivência de pequenos produtores. Devido a extensão territorial de nosso país e a grande quantidade de municípios, onde a Vigilância Sanitária ainda não está devidamente estruturada a comercialização do leite cru pode acontecer sem o controle das autoridades sanitárias.

Na TABELA 6 ainda são observadas análises microbiológicas em amostras de leite pasteurizado tipo $A$, leite pasteurizado tipo $B$ e leite pasteurizado tipo C. A pasteurização é um processo necessário e tem a finalidade de eliminar microrganismos patogênicos, além de diminuir ao máximo o número de microrganismos em geral, mas, alguns deles, ainda podem sobreviver ao tratamento térmico aplicado OLIVEIRA (2005) (anexo 1 - 05M35).

Frente a essa preocupação, OLIVEIRA (2005), em sua dissertação de mestrado (anexo 1 -05M35), avaliou a condição microbiológica e a eficácia 
da pasteurização industrial do leite tipos A, B e C, através da enumeração de bactérias mesófilas, termófilas e psicrófilas, Staphylococcus coagulase positiva, determinação do número mais provável de coliformes totais e fecais e pesquisa de Salmonella spp. em amostras de leite comercializado na cidade de Piracicaba, SP. O autor conclui que a contaminação observada pode ser indicativo de prováveis falhas do binômio tempo $\mathrm{x}$ temperatura durante a pasteurização industrial; matéria-prima excessivamente contaminada; higienização e sanificação deficientes das linhas de produção ou contaminação pós-pasteurização.

O queijo minas é um produto de fácil preparação e é amplamente comercializado. Sua fabricação ocorre, muitas vezes, na propriedade onde é realizada a ordenha e, frequentemente, em precárias condições de higiene. Por ser um produto de paladar agradável e preço acessível, tem boa aceitação pelos consumidores. No Município de São Paulo, esse tipo de queijo é normalmente comercializado nas ruas por vendedores ambulantes, em feiras livres e nos Mercados Municipais, além de outros estabelecimentos (PEDRO, 2005).

LISITA (2005), em sua dissertação de mestrado (anexo 1 - 05M30), avaliou a presença de coliformes totais e fecais, contagem de mesófilos aeróbios e psicrotróficos em 11 amostras de queijo minas. Os resultados encontrados indicam que o queijo Minas frescal estudado, antes de ser embalado, já se apresentava impróprio para o consumo, devido às altas contagens de coliformes totais e fecais podendo vir a causar riscos aos consumidores e que, também, o próprio processo de fabricação foi responsável pela alta contaminação, constituindo um problema de saúde pública.

O leite é considerado o mais completo alimento, possuindo elevado valor biológico na alimentação humana, particularmente nos primeiros estágios de vida, quando se constitui em alimento exclusivo (OLIVEIRA et 
al., 2008). Tendo em vista a vulnerabilidade do recém-nascido em adquirir doenças e infecções em razão de seu imaturo sistema imunológico, foi investigada, também, a qualidade microbiológica de amostras de leite materno provenientes de bancos de leite humano.

De acordo com o observado na TABELA 6, houve contagens elevadas de coliformes totais $(46,26 \%)$, Staphylococcus aureus $(26,53 \%)$, aeróbios mesófilos $(59,18 \%)$ e Bacillus cereus $(13,79 \%)$. Em virtude dos níveis de contaminação observados, BORRELL (2004), em sua tese de doutorado (anexo 1 - 04D05), preconizou condições de coleta, transporte e armazenamento de leite materno para que possa ser usado com segurança sendo armazenado em geladeira a $4^{\circ} \mathrm{C}$ por até 24 horas. 
Tabela 7 - Análises microbiológicas, realizadas em pescados e frutos do mar, de acordo com dados obtidos de dissertações e teses realizadas na Universidade de São Paulo, publicadas entre 1993 e 2007.

\begin{tabular}{|c|c|c|c|c|}
\hline Alimento & $\begin{array}{l}\text { Microrganismos elou } \\
\text { indicadores de } \\
\text { contaminação }\end{array}$ & $\begin{array}{l}\text { Número de amostras } \\
\text { analisadas por } \\
\text { microrganismo elou } \\
\text { indicador de } \\
\text { contaminação }\end{array}$ & $\begin{array}{c}\text { Número de } \\
\text { amostras } \\
\text { contaminadas }\end{array}$ & $\%$ \\
\hline \multirow{18}{*}{$\begin{array}{c}\text { Pescado e } \\
\text { frutos do } \\
\text { mar } \\
(n=621) *\end{array}$} & Coliformes totais & 20 & 14 & 70,00 \\
\hline & Coliformes fecais & 60 & 22 & 36,67 \\
\hline & Escherichia coli & 80 & 18 & 22,50 \\
\hline & S. aureus & 80 & 06 & 7,50 \\
\hline & Salmonella spp. & 112 & 05 & 4,47 \\
\hline & Aeróbios mesófilos & 32 & 17 & 53,12 \\
\hline & Psicrófilos & 32 & 16 & 50,00 \\
\hline & Bacillus cereus & 20 & 02 & 10,00 \\
\hline & Listeria sp. & 255 & 233 & 91,37 \\
\hline & L. monocytogenes & 378 & 109 & 28,83 \\
\hline & Aeromonas sp. & 90 & 29 & 32,22 \\
\hline & Aeromonas sobria & 50 & 0 & 0 \\
\hline & Aeromonas caviae & 50 & 08 & 16,00 \\
\hline & A. hydrophila & 50 & 03 & 6,00 \\
\hline & Aeromonas veronii & 20 & 05 & 25,00 \\
\hline & Vibrio sp. & 60 & 13 & 21,67 \\
\hline & Vibrio vulnificus & 32 & 06 & 18,75 \\
\hline & V. parahaemolyticus & 32 & 07 & 21,87 \\
\hline
\end{tabular}

${ }^{*} \mathrm{n}=$ total de amostras pesquisadas. (Obs.: nem todas as análises foram realizadas para todas as amostras).

Na TABELA 7, observamos os dados de análises microbiológicas realizadas em amostras de pescado e frutos do mar. Os peixes são alimentos altamente perecíveis, apresentando um reduzido prazo de vidade-prateleira (SALGADO et al., 2006) e podem ser agentes de contaminação, como qualquer fonte de proteína de origem animal; representando, portanto, risco para a saúde humana; e podem ser contaminadas a partir de seu meio ambiente natural ou manuseio ou no processamento subseqüente (ADAM e MATARJEMY, 2002). A água, 
salgada ou doce, constitui ambiente natural de uma variedade de bactérias capazes de originar infecção no homem, embora o potencial para isso dependa de fatores, tais como sobrevivência, latência e dose infectante do organismo e suscetibilidade do hospedeiro (SILVA, 2007) (anexo 1 07M01).

SILVA (2007), em sua dissertação de mestrado (anexo 1 - 07M01), investigou a presença de cepas potencialmente patogênicas de Vibrio spp., Aeromonas spp., Escherichia coli, Salmonella spp. e Staphylococcus aureus em peixes comercializados em feiras livres da cidade de São Paulo e constatou que estes alimentos podem representar um sério risco para os consumidores e podem atuar como importante veículo de transmissão de espécies enteropatogênicas.

Ainda em seu estudo, SILVA (2007) (anexo 1 -07M01) comenta que o aumento da poluição do mar e outros corpos hídricos pelo homem também eleva o nível de contaminação dos peixes, bem como a manipulação inadequada do peixe é outro importante fator que contribui com o desenvolvimento de microrganismos patógenos ao homem. Pode ocorrer em toda a complexa cadeia que envolve o pescado, desde o momento de captura até o consumidor final.

Atenta-se para a presença de microrganismos como os do gênero Aeromonas e Vibrio, apesar da pesquisa da maioria das espécies desses gêneros não serem preconizadas na RDC n¹2, de 02/01/2001. 
Tabela 8 - Análises microbiológicas, realizadas em produtos cárneos, de acordo com dados obtidos de dissertações e teses realizadas na Universidade de São Paulo, publicadas entre 1993 e 2007.

\begin{tabular}{c|c|c|c|c}
\hline Alimento & $\begin{array}{c}\text { Microrganismos elou } \\
\text { indicadores de } \\
\text { contaminação }\end{array}$ & $\begin{array}{c}\text { Número de amostras } \\
\text { analisadas por } \\
\text { microrganismo elou } \\
\text { indicador de } \\
\text { contaminação }\end{array}$ & $\begin{array}{c}\text { Número de } \\
\text { amostras } \\
\text { contaminadas }\end{array}$ & $\%$ \\
\hline $\begin{array}{c}\text { Carne bovina } \\
(\mathrm{n}=64)^{*}\end{array}$ & E. coli O157:H7 & 28 & 05 & 17,85 \\
\hline Carne de & C. perfringens & 36 & 11 & 30,55 \\
Frango & Listeria sp. & 413 & 171 & 41,40 \\
$(\mathrm{n}=413)$ & Coliformes totais & 413 & 149 & 36,07 \\
\hline Carne suína & E. coli & 240 & 237 & 98,75 \\
(n=276) $^{*}$ & Salmonella spp. & 240 & 218 & 90,83 \\
& L. monocytogenes & 240 & 13 & 5,42 \\
\hline Carne de & Coliformes totais & 36 & 11 & 30,55 \\
animais & Coliformes fecais & 27 & 0 & 0 \\
silvestres & Salmonella spp. & 27 & 0 & 0 \\
(n=27) & S. aureus & 27 & 02 & 7,40 \\
& Aeróbios mesófilos & 27 & 0 & 0 \\
& Clostridium sulfito-redutores & 27 & 0 & 0 \\
\hline
\end{tabular}

* $\mathrm{n}=$ total de amostras pesquisadas. (Obs.: nem todas as análises foram realizadas para todas as amostras).

Na TABELA 8, observamos os dados de análises microbiológicas realizadas em amostras de produtos cárneos. Em muitos países, carne é o produto associado com maior freqüência aos problemas de segurança microbiológica dos alimentos, por prover as bactérias um meio ideal para que elas possam crescer, através da disponibilidade de nutrientes, água e pH moderado (ADAM e MATARJEMY, 2002).

O índice de contaminação observado em carnes de frango é preocupante, pois o Brasil vem se destacando como o maior exportador mundial de carne de frango, sendo que este é o segundo tipo de carne mais consumido no mundo. Além disso, as alterações de hábitos alimentares da população e o baixo preço da carne de frango são responsáveis por aumentos crescentes no consumo interno deste produto a cada ano (ANDRIGHETO, 2006 - anexo 1 - 06D11; SOUSA et al., 2006). 
O Brasil também é reconhecido como um dos principais exportadores de carne bovina. A maioria do gado é criada a pasto, porém uma parte já é confinada, como, por exemplo na criação de "Novilhos Superprecoces". Este confinamento pode favorecer a contaminação por L. monocytogenes do rebanho (SAKATE, 2005) (anexo 1 - 05D41). Em sua tese de doutorado, o autor detectou que, nesta cadeia produtiva de carne, o principal ponto crítico para L. monocytogenes está na área limpa do frigorífico e que cepas de mesmos grupos clonais puderam ser encontrados em áreas distintas do frigorífico $\mathrm{B}$, demonstrando o alto poder de disseminação destas cepas. Estes resultados podem auxiliar no desenvolvimento de programas de boas práticas e HACCP para prevenir ou eliminar a contaminação por este patógeno.

De acordo com o observado por PANETTA (2008), nestes últimos anos, à luz da Lei Federal n7889, de 1989, vivenciamos uma aplicação irregular, heterogênea, da legislação que ordena a fiscalização industrial e sanitária dos produtos de origem animal: embora a legislação permita que estados e municípios assumam a execução da inspeção sanitária, espelhando-se no que faz o nível federal relativamente à exportação, muitos deles não têm ainda os serviços correspondentes ou, então, os têm precariamente, sem a mínima condição de funcionamento.

PANETTA (2008) ainda ressalta que existe um grande desafio para o Brasil: reequipar e modernizar o seu sistema de inspeção sanitária, para recolocá-lo no lugar que, historicamente, sempre mereceu como guardião da qualidade sanitária dos produtos elaborados para o mercado interno e externo. Haja vista o bloqueio das exportações brasileiras de carne para o continente europeu no ano de 2008, como conseqüência da última visita efetuada pelos agentes sanitários, que atestaram problemas de caráter sanitário e em relação ao sistema de rastreabilidade dos animais. 


\subsubsection{Análise físico-química, nutricional e sensorial de alimentos}

$\mathrm{Na}$ categoria "Avaliação físico-química, nutricional e sensorial de alimentos", das 63 teses e dissertações analisadas (100\%), 23 (36,51\%) realizaram análise das características nutricionais de alimentos, 17 (26,99\%) pesquisaram as características sensoriais de alimentos, 13 (20,63\%) analisaram as características físico-químicas de alimentos, e 10 (15,87\%) analisaram a perda de nutrientes pós processamento de alimentos.

Tabela 9 - Distribuição das teses e dissertações, de 1993 a 2007, de acordo com o tema "Análise físico-química, nutricional e sensorial de alimentos".

\begin{tabular}{l|c|c}
\hline Categorias & N & $\%$ \\
\hline Análise de características nutricionais & 23 & 36,51 \\
Análise de características sensoriais & 17 & 26,99 \\
Análise de características físico-químicas & 13 & 20,63 \\
Análise de perda de nutrientes pós processamento de alimentos & 10 & 15,87 \\
\hline Total & $\mathbf{6 3}$ & $\mathbf{1 0 0}$ \\
\hline
\end{tabular}

As pesquisas bromatológicas abrangeram: análises do teor de umidade, lactose, cinzas, extrato seco total e pH; e as análises sensoriais.

A perda da atividade da vitamina A presente nos pimentões amarelos através do cozimento foi analisada por BIANCHINI (1993) (anexo 1 94M01), em sua dissertação de mestrado. A autora constatou que houve reduções entre 21,08 a $30,80 \%$ dos teores de vitamina $A$.

OLIVO (1999), em sua tese de doutorado (anexo 1 -99D16), estudou a suplementação de vitamina $E$ na dieta de frangos e observou melhoras nas propriedades funcionais de suas carnes. 
MARTINS (2004), em sua dissertação de mestrado (anexo 1 04M26), realizou a análise sensorial de amostras de agrião expostas as doses de 1,3 e 4 kGy, mantidas sob refrigeração, a fim de determinar sua vida-de-prateleira e todas as suas amostras expostas à radiação foram aceitas pelos julgadores. A vida-de-prateleira da amostra de agrião exposta à $1 \mathrm{kGy}$ foi de 16 dias, um dia e meio a mais que a testemunha. A vida-deprateleira das amostras expostas à 3 e 4 kGy foi de 9 e 6 dias, respectivamente.

Esses tipos de análises são fundamentais para a indústria de alimentos, uma vez que esses aspectos são condicionantes de sua aceitabilidade pelos consumidores. Tendo em vista que, a Vigilância Sanitária é um conjunto de ações capazes de eliminar, diminuir ou prevenir riscos à saúde (BRASIL, 1990b), estes aspectos não devem passar despercebidos pelos profissionais da área.

De acordo com PANETTA (2004), qualidade e segurança são componentes indispensáveis para produtos alimentares e as indústrias conhecem bem os benefícios advindos ao se trabalhar corretamente os alimentos, garantindo suas propriedades nutricionais, tecnológicas e sanitárias. $\mathrm{O}$ autor enfatiza que alimento seguro significa alimento que, além de apresentar as propriedades nutricionais esperadas pelo consumidor, não Ihe cause danos à saúde, não lhe tira o prazer que o alimento deve oferecer, não the roube a alegria de alimentar-se correta e seguramente. 


\subsubsection{Conservação de Alimentos}

$\mathrm{Na}$ categoria "Conservação de alimentos", das 42 teses e dissertações analisadas (100\%), 12 (28,57\%) realizaram análise da conservação pós-colheita de alimentos, 09 (21,43\%) determinaram o tempo de prateleira de alimentos, $07(16,67 \%)$ avaliaram o uso de embalagens, 06 $(14,28 \%)$ avaliaram o uso do binômio tempo $X$ temperatura, 04 (9,53\%) avaliaram o uso de atmosfera modificada (ATM), 03 (7,14\%) determinaram a vida útil em ATM, e 01 (2,38\%) analisaram a conservação de alimentos sem adição de conservantes químicos.

Tabela 10 - Distribuição das teses e dissertações, de 1993 a 2007, de acordo com o tema "Conservação de alimentos".

\begin{tabular}{l|c|c}
\hline Categorias & $\mathbf{N}$ & $\%$ \\
\hline Conservação pós-colheita & 12 & 28,57 \\
Determinação do tempo de prateleira & 09 & 21,43 \\
Avaliar uso de embalagens & 07 & 16,67 \\
Uso de tempo X temperatura & 06 & 14,28 \\
Uso de atmosfera modificada (ATM) & 04 & 9,53 \\
Vida útil em atmosfera modificada (ATM) & 03 & 7,14 \\
Conservação sem adição de conservantes químicos & 01 & 2,38 \\
\hline Total & $\mathbf{4 2}$ & $\mathbf{1 0 0}$ \\
\hline
\end{tabular}

BLUMER (1995), em sua dissertação de mestrado (anexo 1 - 95M01), avaliou a conservação de um suco natural de maçã, sem a utilização de conservantes químicos e a dose de 6kgy manteve as características do suco, proporcionando um melhor aspecto, sem microorganismos, com valor de aceitabilidade de 8,2 numa escala de 9 pontos. 
Com o objetivo de aumentar a vida útil e a qualidade do figo roxo de Valinhos após a colheita, PENTEADO (1998) em sua tese de doutorado (anexo 1 - 98D04), pesquisou as duas fases de maturação do fruto e temperaturas de armazenamento, vários métodos de conservação, empregando embalagens em atmosfera modificada e substâncias ativas. De acordo com o autor, as embalagens fresh paper, PEBD, PEBD+CH e confresh evitaram a perda de peso das caixetas de figo, bem como manteve a rigidez de polpa. A temperatura de $0^{\circ} \mathrm{C}$ favoreceu a conservação do figo, porém torna o fruto colhido na fase meio maduro suscetível a ocorrência de substância gelatinosa no interior da polpa. $\mathrm{O}$ autor também detectou que a principal podridão que ocorre na fase de pós-colheita no figo roxo de Valinhos, é causada pelo fungo Rhisophus nigri spp.

As frutas deterioraram-se em poucos dias, tendo sua comercialização in natura dificultada a grandes distâncias. Além disso, estima-se que as perdas pós-colheita variem de 15 a $50 \%$ do total. Tendo em vista estes aspectos, SANTOS (2005) em sua dissertação de mestrado (anexo 1 05M01) propôs a produção de polpas de frutas congeladas como um meio favorável para o seu aproveitamento integral na época da safra, evitando os problemas ligados à sazonalidade. $\mathrm{O}$ autor observou que $\mathrm{o}$ armazenamento de polpas congeladas de morango, amora, açaí e acerola em condições comerciais $\left(-18{ }^{\circ} \mathrm{C}\right)$, por até um ano, não afeta os teores de flavonóides, vitamina $\mathrm{C}$, fenólicos totais e atividade antioxidante.

Levando em consideração o elevado índice de perdas pós-colheita que ocorre no Brasil, impedindo que de 20 a $30 \%$ das hortaliças e frutas produzidas e que saem do campo cheguem ao consumidor final, embalagens adequadas para a comercialização podem contribuir para reduzir essas perdas. LUENGO (2005) em sua tese de doutorado (anexo 1 05D48) buscou dimensionar embalagens para comercialização das principais espécies de hortaliças e frutas comercializadas no Brasil, considerando a proteção da carga, quanto a danos mecânicos, o 
atendimento à legislação brasileira, a adequação de logística e o atendimento a critérios ergonômicos para proteger a saúde do operador.

LUENGO (2005) (anexo 1 - 05D48) desenvolveu metodologias específicas para alcançar o objetivo proposto, como os métodos para determinação das alturas potenciais de embalagens para frutas e hortaliças arredondadas e para hortaliças folhosas, e da balança hidrostática acoplada à embalagem, que permite medir a pressão a que os frutos ficam sujeitos com o fechamento da caixa. Além de métodos e conhecimentos biomecânicos, foram propostos novos modelos de embalagens para comercialização de hortaliças e frutas, gerando uma família de caixas constituída de tamanhos diferentes. Estes modelos possuem medidas externas de $50 \mathrm{~cm}$ de comprimento, 30 ou $60 \mathrm{~cm}$ de largura e 17,5; 23 ou 35 $\mathrm{cm}$ de altura. A autora constatou que este número reduzido de modelos é valioso para as necessidades logísticas de embalagens que se encaixem entre si, e para facilitar a composição de páletes mistos, muito freqüentes na comercialização de frutas e hortaliças no Brasil e em outros países.

ANDRADE (2006), em sua dissertação de mestrado (anexo 1 06M02), concluiu que o uso de atmosfera modificada ativa mostrou-se eficiente no retardamento da proliferação de microorganismos psicrotróficos, nas amostras de mamões analisados durante seu estudo.

Como o uso de atmosfera modificada (ATM) na embalagem de cortes cárneos tem sido uma alternativa para melhorar a qualidade do produto, BARACAT (2006) em sua tese de doutorado (anexo 1 - 06D06), não detectou as presenças de Salmonella e de Coliformes fecais, e nem de Clostridium em nenhuma das amostras analisadas de carne crua, e as contagens detectadas de Coliformes totais estavam abaixo do limite especificado para este tipo de alimento. Desta forma, a autora concluiu que as carnes armazenadas em ATM, por um período de até 28 dias, não comprometem a qualidade visual e sensorial dos produtos. 
Como pôde ser observado, as pesquisas analisadas nesse estudo avaliaram e desenvolveram alguns métodos de conservação de alimentos, fator este que chama a atenção para a mudança nas escolhas alimentares da população. A alimentação tradicional vem perdendo espaço para novas práticas alimentares (PIPITONE, 2005) e a preferência atual dos consumidores é por refeições mais convenientes no que se refere à facilidade, seja na sua aquisição e preparo, economizando tempo, seja no seu consumo fora do domicílio (DALLARI et al., 2000; DE DEUS et al., 2005; FATTORI et al., 2005), nas proximidades do local de trabalho (MORAES et al., 2005; SILVA et al., 2005).

Face à essa nova demanda, métodos e técnicas de preservação dos alimentos e de proteção à saúde dos consumidores têm sido desenvolvidos por pesquisadores preocupados com a saúde coletiva (PANZA et al., 2006).

Nas últimas décadas, a indústria de alimentos tem sofrido profundas transformações, dentre as quais cabe ressaltar a introdução de operações automatizadas e de alta velocidade, novas embalagens, novas formulações e sistemas de distribuição eficientes. Muitas vezes, grandes volumes de produto são enviados, logo após a produção, para os centros de distribuição e comercialização, estando à disposição dos compradores pouco tempo após a produção (DESTRO, 2002).

O desenvolvimento de novas embalagens, especialmente as de atmosfera modificada, é um assunto contemporâneo. O aumento no consumo de alimentos acondicionados em ATM pode implicar em um risco diferenciado, pois um possível surto passa ter proporções e características diferentes, podendo afetar grande parcela da população. Por isso, faz-se necessária a consideração de novas tecnologias pelos profissionais de Vigilância Sanitária, para que tenham uma constante capacitação, a fim de que suas práticas sejam coerentes, atuando na prevenção de riscos à saúde da população. 


\subsubsection{Irradiação de alimentos}

$\mathrm{Na}$ categoria "Alimentos irradiados", das 39 teses e dissertações analisadas, 17 (43,59\%) determinaram a dose de radiação gama para destruir microrganismos, 09 (23,08\%) determinaram a dose de radiação gama para conservação de alimentos, 07 (17,95\%) avaliaram os efeitos da radiação no teor nutritivo de alimentos, 03 (7,69\%) avaliaram o uso de embalagem submetida à radiação ionizante, 02 (5,13\%) avaliaram a influência das doses de radiação gama na qualidade do alimento, e 01 $(2,56 \%)$ avaliou o efeito da radiação na maturação de alimentos.

Tabela 11 - Distribuição das teses e dissertações, de 1993 a 2007, de acordo com o tema "Irradiação de alimentos".

\begin{tabular}{l|c|c}
\hline Categorias & $\mathbf{N}$ & $\mathbf{\%}$ \\
\hline Determinar dose de radiação gama para destruir microrganismos & 17 & 43,59 \\
Determinar dose de radiação gama para conservar alimentos & 09 & 23,08 \\
Efeitos da radiação no teor nutritivo dos alimentos & 07 & 17,95 \\
Avaliação de embalagem submetida à radiação ionizante & 03 & 7,69 \\
Influência das doses de radiação gama na qualidade do alimento & 02 & 5,13 \\
Radiação na maturação de alimentos & 01 & 2,56 \\
\hline Total & $\mathbf{3 9}$ & $\mathbf{1 0 0}$ \\
\hline
\end{tabular}

A irradiação de alimentos é permitida em quase 40 países e é endossada pela Organização Mundial de Saúde (OMS), pela Associação Médica Americana e muitas outras entidades (ZANÃO, 2007) (anexo 1 07M08).

O processo de irradiação surge como resposta à necessidade de produtos alimentares seguros, devido à crescente demanda da população mundial, reduzindo as perdas por deterioração e prevenindo as 
enfermidades veiculadas por alimentos (SOARES et al., 2008). Não obstante, é importante destacar que a irradiação dos alimentos não substitui a manipulação adequada dos produtos, pois não é capaz de transformar um alimento deteriorado em alimento de alta qualidade (ALFEREZ, 2008; SOARES et al., 2008).

O FDA (2004) apud ZANÃO (2007) (anexo 1 - 07M08) aprovou a irradiação de carne e aves e permite seu uso para uma variedade de outros alimentos, como frutas e legumes frescos e condimentos. Segundo o FDA, o processo de irradiação é seguro e efetivo, reduzindo ou eliminando microrganismos patogênicos, deteriorantes, insetos e parasitas e, em certas frutas e legumes, inibe o brotamento e retarda o amadurecimento.

Os países membros da União Européia, através do Conselho e do Parlamento Europeu, aprovam a irradiação de ervas aromáticas desidratadas, especiarias e condimentos vegetais. Alguns países, como a Bélgica, França e Holanda são autorizados a tratar alimentos como peixes, crustáceos e moluscos, entre outros, com radiação ionizante (PARLAMENTO EUROPEU, 2008).

Na América do Sul, apenas três países: Brasil, Argentina e Chile, possuem legislação para irradiação de alimentos (OLIVEIRA e SABATO, 2000).

O tratamento por radiação gama é uma das tecnologias de descontaminação e conservação de alimentos que vem crescendo em todo o mundo, ainda pouco difundida, mas já aprovada no Brasil pela ANVISA, através da Resolução RDC 21/2001 (BRASIL, 2001) (VIEIRA et al., 2007). O processo consiste em submeter o produto a uma quantidade minuciosamente controlada de radiação ionizante por um tempo determinado, sem que o alimento entre em contato direto com a fonte de radiação. $O$ processo de irradiação não aumenta o nível de radioatividade 
normal dos alimentos, independente do tempo de exposição ou da dose absorvida e, uma vez interrompida a emissão de energia, os efeitos da irradiação não persistem no alimento irradiado (IAEA, 1991).

A irradiação é utilizada tanto em matérias primas quanto em produtos industrializados e prontos para consumo. A legislação vigente estabelece que:

Qualquer alimento pode ser tratado por radiação ionizante desde que a dose mínima absorvida seja o suficiente para alcançar a finalidade pretendida e que a dose máxima absorvida seja inferior àquela que comprometeria as propriedades funcionais e ou os atributos sensoriais do alimento (BRASIL, 2008).

A radiação gama, utilizada para adiar a deterioração de carne pode causar odor e sabor desagradáveis e alteração da cor em embalagens contendo oxigênio. Este problema pode ser solucionado utilizando vácuo e congelamento. Por isso, MORENO (2001) em sua tese de doutorado (01D03), avaliou o efeito da irradiação gama, embalagem e temperatura sobre a qualidade da carne. A autora verificou que os números de psicrotróficos foi reduzido. Esporos foram encontrados em amostras controle e irradiados em todas as embalagens. Salmonella sp e $S$. aureus não foram detectados. A temperatura não teve efeito sobre a radiorresistência dos microrganismos $A$ melhor combinação para carne refrigerada foi $2 \mathrm{kGy}$ e embalagem a vácuo e para as congeladas foi de 3 kGy em aerobiose.

Com o objetivo de prolongar o tempo de vida comercial do pescado beneficiado, através da utilização das radiações ionizantes, associadas às técnicas complementares de refrigeração, SIQUEIRA (2001) em sua dissertação de mestrado (anexo 1 - 01M10), analisou aspectos físicos, químicos, nutricionais e microbiológicos de tilápias evisceradas e em cortes comerciais, separadas em amostras irradiadas com 1; 2,2 e 5 kGy e não irradiadas, armazenadas sob refrigeração na faixa de 0,5 a $-2^{\circ} \mathrm{C}$, durante 20 e 30 dias. $\mathrm{O}$ acompanhamento microbiológico para coliformes totais e fecais 
durante o período de armazenamento, permitiu verificar a eficácia da irradiação, uma vez que, as amostras irradiadas apresentaram contagens microbiológicas abaixo dos valores mínimos estabelecidos pela legislação para pescado, fato que não ocorreu para as amostras não irradiadas. Salmonella e S.aureus não foram detectados nas amostras irradiadas. A boa aceitação para aparência, aroma, cor e textura obtida na análise sensorial dos produtos armazenados por um período de 30 dias, mostrou a viabilidade do processo combinado de irradiação e refrigeração quanto à intenção de estender a vida útil das tilápias submetidas ao processamento mínimo.

A vida de prateleira ou estabilidade da carne fresca mantida sob refrigeração é fortemente influenciada pelo desenvolvimento de microrganismos. O uso da radiação tem se mostrado como um método eficiente no controle de microrganismos em alimentos, sem alterar significativamente suas características organolépticas e nutricionais, promovendo tanto o aumento da segurança higiênico-sanitária bem como a vida de prateleira desses produtos alimentícios (MACHADO et al., 2006; OLIVEIRA et al., 2006; TAIPINA et al., 2006).

Contudo, além das inúmeras vantagens, existem, também, algumas desvantagens na irradiação de alimentos, como possíveis alterações no produto final, como descritas por ROCHA et al. (2007):

- Os radicais livres fazem com que o alimento adquira sabor desagradável, característico de alimentos irradiados. Alterações de cor também podem ser observadas em carnes e peixes;

- As proteínas, o amido e a celulose podem ser quebrados por ação das radiações sofrendo modificações benéficas, como o amolecimento de carnes, ou maléficas como a perda de nutrientes;

- As vitaminas $C$, tiamina e $\mathrm{K}$ sofrem alterações semelhantes às observadas no processamento térmico. Os radicais livres 
produzidos com as radiações provocam oxidação das gorduras do alimento, um processo que é responsável pelo sabor rançoso em produtos gordurosos.

CESTARI Jr (2005), em sua dissertação de mestrado (anexo 1 05M04), avaliou o potencial de aplicação do processo de irradiação para a redução de Salmonella spp. em diferentes variedades de mangas (Mangifera indica L.) minimamente processadas, bem como a avaliação da vida de prateleira. $\mathrm{O}$ autor observou que todas as amostras irradiadas foram aceitas pelos provadores. A vida de prateleira da amostra de manga variedade Tommy Atkins exposta a $1 \mathrm{kGy}$ foi de 4 dias, dois dias a mais que a amostra controle e que a amostra exposta 2 kGy. No caso da amostra de manga da variedade Haden todas as amostras irradiadas e a amostra controle apresentaram vida de prateleira de 4 dias. $\mathrm{O}$ autor concluiu que a irradiação mostrou ser um processo adequado para aumentar a segurança microbiológica de mangas minimamente processadas e, dependendo da variedade, também prolonga sua vida de prateleira.

ZANÃO (2007), em sua dissertação de mestrado (anexo 1 - 07M08), constatou que o uso da radiação gama não afetou o rendimento do arroz após o beneficiamento. As doses de 0,5 e 1,0 kGy foram efetivas no controle do inseto Sitophilus oryzae $L$. no arroz. A autora observou que as amostras irradiadas não alteraram a composição centesimal, no arroz cru e cozido e que, no teste sensorial do arroz cozido, a dose de 1,0 kGy foi a que obteve melhores médias, e melhor aceitação pelos provadores.

O interesse pela irradiação como tecnologia de tratamento de alimentos tem forte justificativa econômica devido às grandes perdas decorrentes da infestação por insetos e da contaminação e deterioração por microrganismos. A radiação ionizante é capaz de esterilizar e/ou reduzir a carga microbiológica a níveis seguros para o consumo, permitindo ainda ampliar o tempo de armazenamento dos produtos alimentícios. E, ainda, é 
considerada como um método limpo de conservação, pois não gera poluentes atmosféricos (SPOTO. 1998 apud VIEIRA et al., 2007; LIMA et al., 2008), o que vem de encontro à preocupação da vigilância ambiental em relação ao esgotamento dos recursos naturais.

No entanto, para garantir a inocuidade dos alimentos, é necessária a interação entre esse processo e as Boas Práticas de Fabricação (BPF), ressaltando a importância, principalmente, da manipulação adequada dos produtos. Algumas linhas científicas reprovam a utilização de tecnologias destinadas à redução da carga microbiana de alimentos, baseadas na hipótese de que a falta de competitividade poderia favorecer o desenvolvimento de microrganismos patogênicos veiculados acidentalmente ao alimento pós-processamento (SOARES et al., 2008).

Apesar de a irradiação de alimentos ser um método extremamente vantajoso, existem ainda dificuldades de aceitação pelos consumidores. ORNELAS et al. (2006) realizaram uma pesquisa de opinião e verificaram que para $16 \%$ do público entrevistado, dos quais $94 \%$ com, pelo menos, o segundo grau completo, "alimentos irradiados" significam o mesmo que "alimentos radioativos", o que evidencia a falta de conhecimento do público sobre esse tipo de procedimento. É importante que os consumidores superem alguns mitos e entendam que a irradiação não torna o alimento radioativo e não destrói nutrientes em maior extensão que outros processos de conservação (MARTIN-NETO, 1996 apud VIEIRA et al., 2007).

Segundo VIEIRA et al. (2007), quando o mercado consumidor aceitar melhor o tratamento de alimentos pelo processo de irradiação, provavelmente as análises de controle se farão ainda mais necessárias e, assim, haverá o interesse e, também, a necessidade da aquisição de tecnologia de ponta, pois já existem equipamentos de custo mais baixo, por laboratórios conveniados às Vigilâncias Sanitárias estaduais e municipais. 


\subsubsection{Análise de resíduos em alimentos}

$\mathrm{Na}$ categoria "Análise de resíduos em alimentos", das 34 teses e dissertações analisadas, 19 (55,89\%) quantificaram resíduos de pesticidas / químicos em alimentos, 09 (26,47\%) apenas detectaram resíduos de pesticidas / químicos em alimentos, 03 (8,82\%) removeram resíduos de pesticidas / químicos presentes nos alimentos analisados, 01 (2,94\%) avaliaram a influência do tratamento inseticida na qualidade dos alimentos, 01 (2,94\%) detectou a presença de componentes inorgânicos em alimentos, e 01 (2,94\%) analisou os efeitos da transferência de metais para os alimentos.

Tabela 12 - Distribuição das teses e dissertações, de 1993 a 2007, de acordo com o tema "Análise de resíduos em alimentos".

\begin{tabular}{l|c|c}
\hline Categorias & $\mathbf{N}$ & $\%$ \\
\hline Quantificar resíduos de pesticidas / químicos em alimentos & 19 & 55,89 \\
Detectar resíduos de pesticidas / químicos em alimentos & 09 & 26,47 \\
Remover resíduos de pesticidas / químicos em alimentos & 03 & 8,82 \\
Avaliar tratamento inseticida na qualidade dos alimentos & 01 & 2,94 \\
Detectar componentes inorgânicos em alimentos & 01 & 2,94 \\
Verificar transferência de metais para os alimentos & 01 & 2,94 \\
\hline Total & $\mathbf{3 4}$ & $\mathbf{1 0 0}$ \\
\hline
\end{tabular}

Classificaram-se como resíduos pesticidas: os resíduos de agrotóxicos, de herbicidas, de fungicidas e de pesticidas. E classificaram-se como resíduos químicos: cromo, chumbo, alumínio, níquel, ferro, arsênio e mercúrio. 
A legislação determina que o registro para um novo produto agrotóxico seja somente concedido se a sua ação tóxica sobre o ser humano e o meio ambiente for comprovadamente igual ou menor do que a daqueles já registrados para o mesmo fim. A legislação também proibiu o registro de agrotóxicos que revelem características teratogênicas, carcinogênicas ou mutagênicas (BRASIL, 1998).

Através da Lei 7802, de 11 de julho de 1989, e da Portaria $n^{0} 03$, de 16 de janeiro de 1992, têm-se as diretrizes para a utilização de pesticidas no Brasil. Os Ministérios da Saúde, Agricultura e o Instituto Brasileiro do Meio Ambiem e Recursos Naturais Renováveis (IBAMA), cada um na sua área de atuação ficam como os responsáveis pela autorização ou não da utilização dos pesticidas no Brasil. Compete aos Estados e ao Distrito Federal, legislar bem como fiscalizar sobre o uso, a produção, o consumo, o comércio e o armazenamento dos agrotóxicos, seus componentes e afins (MACIEL, 2005) (anexo 1 - 05M18).

A Resolução RDC $\mathrm{n}^{0}$ 44, de 10 de maio de 2000, altera as Diretrizes e Exigências Referentes a Autorização de Registro de Produtos Agrotóxicos e Afins, $n^{0} 1$, de 09 de dezembro de 1991, ratificada pela Portaria $n^{\circ} 03$, de 16 de janeiro de 1992 (título de acordo com o Decreto 991/93). As substituições mais significativas são: a) proposições quanto ao Limite Máximo de Resíduos (LMR) baseadas nas tabelas individuais apresentadas, referentes aos três ensaios de campo ou a dois ensaios pós-colheita, nos casos de Limites de Resíduos Estranhos (LME) estes também deverão ser propostos; b) delineamento experimental; c) unificação e padronização nos estudos de resíduo, onde a informação de campo e do laudo analítico passa a ter critérios mínimos a serem seguidos, os ensaios destinados a pesquisa de resíduos deverão ser conduzidos, no mínimo, em três áreas distintas representativas do cultivo na mesma safra ou em duas safras consecutivas no mesmo local e outro, em local diferente. Para pós-colheita, deverão ser conduzidos, no mínimo, dois ensaios de pesquisa de resíduos, em local 
representativo da operação de tratamento (MACIEL, 2005) (anexo 1 05M18).

Os Limites Máximos de Resíduos (LMRs) de agrotóxicos, bem como a padronização internacional aplicada aos alimentos negociados no mercado mundial, são determinados pela Comissão Codex Alimentarius (CODEX). Um excesso de resíduos, segundo os padrões do CODEX, indica dois aspectos: primeiro, que os agrotóxicos foram aplicados de maneira inadequada na produção, processamento ou armazenagem do produto; e em segundo lugar, que há um risco em potencial à saúde do consumidor (BULL e HATHAWAY, 1986 apud MACIEL, 2005) (anexo 1 - 05M18).

CHICOUREL (1993) (anexo 1 - 93M04), em sua dissertação, pesquisou os teores de mercúrio em cinco espécies de pescado comercializadas na cidade de São Paulo e o efeito do modo de preparo para o consumo sobre os níveis desse metal. A fritura em óleo de soja e a assadura em forno de microondas não apresentaram a capacidade de reduzir o mercúrio somente no cação-azul.

$\mathrm{Na}$ pesquisa realizada por LEMES (2003) (anexo 1 - 03M02), é enfocado o perigo de resíduos fungicidas em alimentos, especialmente a etilenotiouréia (ETU), que é formada pela degradação e/ou biotransformação dos fungicidas etilenobisditiocarbamatos (EBDC). Em sua dissertação de mestrado, a autora constatou a presença desse resíduo em mamão e, em sua tese de doutorado (2007), quantificou a quantidade de resíduo de etilenotiouréia em frutas comercializadas em São Paulo. Nesse estudo, foi detectado que 33\% das amostras de maçã, $67 \%$ das amostras de mamão e 7\% das amostras de morango, apresentavam níveis elevados desse resíduo fungicida. A autora ainda alerta que esses resíduos têm a capacidade de induzir tumor na tireóide de roedores e no fígado de camundongos, apresentando evidência suficiente para carcinogenicidade em animais e 
embora ainda haja evidência inadequada para carcinogenicidade em seres humanos.

ALMEIDA (2005) (anexo 1 - 05M22) pesquisou os teores de arsênio total em cação em sua dissertação de mestrado e constatou que $89 \%$ das amostras continham teores acima de $1 \mathrm{mg} / \mathrm{Kg}$, que é o limite admitido pela legislação brasileira. $O$ autor enfatiza que o arsênio é um importante contaminante, pode estar presente em alimentos e no meio ambiente, e seus efeitos tóxicos no organismo humano envolvem o sistema respiratório, gastrintestinal, cardiovascular, nervoso e hematopoiético.

Um dado interessante foi o publicado por CELLA (2002) (anexo 1 02M27). Em sua dissertação de mestrado a autora identificou e quantificou a ocorrência de agrotóxicos em maçãs e observou uma maior incidência de resíduos nas amostras de casca e fruto inteiro, concluindo que a casca pode funcionar como uma barreira de proteção do fruto contra a entrada de agrotóxicos.

PARMIGIANI (1993), em sua dissertação de mestrado (anexo 1 93M07), cita que dentre os inúmeros contaminantes químicos dos alimentos, destaca-se o chumbo, por estar amplamente distribuído na natureza e também por ser considerado a causa de vários casos de intoxicações principalmente em crianças.

DUARTE (1996) (anexo 1 - 96M08) propôs um método para determinação de nitratos e nitritos em amostras de leite em pó integral, pasteurizado e mistura de leite pasteurizado com soro de leite, na proporção de 1:1. O método utilizado pelo autor foi o espectrofotométrico na região do visível, tendo sido os nitratos reduzidos a nitritos, em uma coluna de cádmio. Os resultados obtidos por DUARTE (1996) (anexo 1 - 96M08) indicaram uma boa exatidão e precisão do método proposto. 
Entretanto, dentre as teses e dissertações analisadas nesse estudo não foram observadas pesquisas que avaliassem a exposição humana a agrotóxicos. Pois se constitui em um grave problema de saúde pública em todo o mundo, principalmente nos países em desenvolvimento (KONRADSEN et al., 2003). Em 2005, mais de 5000 casos de intoxicação por agrotóxicos de uso agrícola foram notificados no Brasil, números que podem estar subestimados considerando-se a elevada sub-notificação desses eventos no país (RECENA e CALDAS, 2008).

A dificuldade em controlar os efeitos provocados pelo uso de agrotóxicos em alimentos está no fato de que essa é uma contaminação invisível. Se para o consumidor, o maior risco é a longo prazo, para o trabalhador rural o problema é imediato. A falta de orientação adequada também acaba deixando os pequenos agricultores em uma situação de maior exposição ao risco. Além de trazer problemas para a saúde do trabalhador rural, a falta de instrução correta pode gerar reflexos na mesa do consumidor (ANVISA, 2006).

Com a preocupação voltada para a qualidade dos alimentos destinados ao consumo humano, BOCALON (2005), em sua dissertação de mestrado (anexo 1 - 05M07), avaliou a transferência dos metais alumínio, cromo, ferro e níquel durante o cozimento dos alimentos arroz e feijão em recipientes de alumínio e aço inoxidável. A autora constatou que, basicamente, não há transferência de metais do recipiente (novo) de teflon para a água de cozimento. As panelas de alumínio e aço inox transferiram os íons Alumínio e Ferro para o arroz, mas não seguiram qualquer linearidade com o tempo de cozimento, notando-se apenas uma transferência mais acentuada quando se fez uso da água padrão de salinidade $10 \mathrm{~g} / \mathrm{L}$. A panela de alumínio e o recipiente de aço inox também transferiram os íons de Alumínio e Ferro para o feijão, sendo que as concentrações mostraram-se concordantes. 
BOCALON (2005) (anexo 1 - 05M07) concluiu que os íons de Cromo e Níquel não são transferidos em níveis detectáveis dos recipientes para a água e desta para os alimentos durante o cozimento. No entanto, os metais Alumínio e Ferro obtiveram aumento de suas concentrações durante toda a parte experimental. A autora concluiu, ainda, que a migração dos íons metálicos é maior em panelas de pressão do que em panelas normais.

O risco dessas irregularidades para a saúde humana não é imediato, mas os danos causados pelo consumo de produtos com esses resíduos a longo prazo precisam ser levados em consideração (ANVISA, 2006). Há uma preocupação diferenciada em relação a transferência do alumínio para os alimentos, em virtude de haver inúmeros artigos publicados considerando este metal como potencial agente etiológico para o Mal de Alzheimer, e, apesar dos esforços sensíveis da ciência em busca da cura para esta enfermidade, o tratamento atual permite somente suavizar seus efeitos.

De acordo com SIMÕES (2005), o recurso humano é o mais rico instrumento de trabalho da Vigilância Sanitária e, por conta disso, há necessidade que os profissionais que atuam na área acompanhem, muito de perto, o desenvolvimento social e tecnológico no Brasil. Com isso, as pesquisas de análise de resíduos em alimentos são relevantes para a Vigilância Sanitária de Alimentos, visto que ela tem a responsabilidade de promover e proteger a saúde da população de possíveis riscos. 


\subsubsection{Análise de Perigos e Pontos Críticos de Controle - APPCC}

APPCC é o principal sistema para o controle de qualidade dos alimentos. Sua importância e implantação foi alvo de estudo das 11 pesquisas pertencentes à categoria "APPCC". Como pode ser observado na TABELA 11, das 11 teses e dissertações analisadas, 07 (63,63\%) identificaram pontos críticos, e 04 (36,36\%) implantaram o método APPCC.

Tabela 13 - Distribuição das teses e dissertações, de 1993 a 2007, de acordo com o tema "APPCC".

\begin{tabular}{l|c|c}
\hline Categorias & N & \% \\
\hline Identificação de pontos críticos & 07 & 63,63 \\
Implantação de APPCC & 04 & 36,36 \\
\hline Total & $\mathbf{1 1}$ & $\mathbf{1 0 0}$ \\
\hline
\end{tabular}

A implantação do sistema APPCC preconiza a aplicação de medidas preventivas e corretivas e o envolvimento da equipe para seu êxito, exigindo a obediência de uma série de etapas que devem ser desenvolvidas e constantemente reavaliadas (LOVATTI, 2004).

ADDÔR (2004) (anexo 1 - 04M35) determinou os pontos críticos durante o processo de importação de produtos termolábeis, identificando seu fluxo de carga, com base no processo documental e operacional da importação de produtos sujeitos ao Controle Sanitário e detectou, entre outros aspectos, o desconhecimento do importador e do exportador dos documentos utilizados no processo de informação; a inexistência de 
informações precisas a respeito das condições ambientais requeridas, para transporte e armazenagem adequada do produto, nos documentos de importação; a não certificação de boas práticas de produção; a ausência de certificação de boas práticas das empresas de transportes envolvidas no fluxo da importação; e conclui que conhecendo os pontos críticos e adotando medidas necessárias pode-se evitar ou minimizar riscos à saúde pública, durante o processo de importação.

TRINDADE (2006), em sua dissertação de mestrado (anexo 1 06M30), forneceu subsídios para a implementação do sistema de qualidade APPCC na produção de fórmulas infantis em lactário a fim de obter um alimento seguro. As informações obtidas durante o estudo, subsidiaram a elaboração dos fluxogramas de produção dessas fórmulas permitindo a identificação dos perigos e pontos críticos de controle com base na avaliação dos ingredientes e etapas do processo. Um plano APPCC foi proposto onde foram apresentados perigos, medidas preventivas, pontos de controle e/ou pontos críticos de controle, limites críticos, monitoração, ações corretivas e procedimentos de verificação. A autora ressalta que a garantia da produção segura das fórmulas infantis a partir do sistema APPCC poderá ser alcançada com investimentos na capacitação de pessoal e adequação das instalações e equipamentos.

O lactário é a unidade de alimentação que atende recém-nascidos e demais pacientes hospitalizados, inclui crianças acima de um ano de idade até adolescência, que necessite receber fórmula infantil em mamadeira ou chuca TRINDADE (2006) (anexo 1 - 06M30). Os lactários são de relevância para a saúde pública, por estarem, muitas vezes, relacionados com infecção hospitalar em crianças, pois esses indivíduos apresentam maior vulnerabilidade às complicações causadas pelas doenças de origem alimentar devido à situação de enfermidade e hospitalização em que se encontram e, da mesma forma, pela imaturidade de seu aparelho digestório e imunológico. 
As doenças transmitidas por alimentos estão presentes em todos os países, desenvolvidos ou em desenvolvimento, atingindo um público vulnerável, como crianças sadias, e podem levar a danos irreparáveis e a implementação do sistema APPCC é relevante no processo de redução do risco de ocorrer doenças decorrentes ao consumo de alimentos (ARIASECHANDI e ANTILLÓN, 2000).

Essas constatações salientam a importância e o interesse da Universidade no controle na produção da alimentação servida em ambiente hospitalar, visto que as crianças hospitalizadas estão sujeitas ao maior risco quando expostas aos alimentos contaminados comparadas à população infantil sadia.

NOGUEIRA (2000), em sua dissertação de mestrado (00M13), verificou a aplicabilidade do uso do sistema APPCC no processamento de farinha de trigo integral, um produto com demanda crescente no mercado. $\mathrm{O}$ autor concluiu que sistema APPCC se aplica aos moinhos de trigo e os auxilia a controlar sua produção do ponto de vista da segurança alimentar.

A importância da implantação do sistema APPCC em moinhos de trigo foi avaliada por LOPES (2002), em sua dissertação de mestrado (02M23), em três moinhos nas regiões sul e sudeste do Brasil. As análises de verificação em farinha de trigo, feitas pela autora, apontaram que essas medidas de controle reduziam o risco de rejeição do produto por empresas clientes fabricantes de produtos derivados de trigo que adotam critérios microbiológicos bastante restritivos, mais rigorosos que os estabelecidos pela legislação pertinente.

Os farináceos são alimentos de importância, em termos de saúde pública, por serem altamente energéticos e consumidos pela maioria da população. Por isso a necessidade e a preocupação da Universidade com a 
qualidade dos alimentos desse grupo, aliado aos riscos que estes podem trazer, ocasionalmente, à saúde da população.

É sabido que surtos de toxinfecções alimentares ocorrem mais freqüentemente em refeições produzidas em grande escala por envolverem um maior número de procedimentos e pontos de perigo de contaminações que, por sua vez, expõem esses consumidores ao risco de contraírem doenças veiculadas por alimentos (DALLARI et al., 2000; SIMÕES, 2005). Dessa forma, os sistemas APPCC/BPF são de fundamental importância para o oferecimento de alimentos seguros e de qualidade, e para a competitividade e crescimento do mercado do segmento de alimentos (NASCIMENTO e BARBOSA, 2007).

É importante ressaltar que não há um modelo único, capaz de atender a todo e qualquer tipo de estabelecimento ou alimento elaborado. O sistema APPCC deve ser planejado e implementado de acordo com a realidade de cada estabelecimento.

As pesquisas nessa área mostraram que são necessários programas de educação e treinamentos direcionados aos fabricantes de alimentos, manipuladores e comerciantes, bem como os profissionais que atuam na importação de produtos, enfocando o controle das matérias primas, os cuidados que são necessários em cada etapa do processamento; orientando-os, também, sobre os fatores que influem sobre a produção, além do alerta e a orientação ao público consumidor com relação a esses problemas.

Os dados dessas pesquisas podem servir como subsídios à ação da Vigilância Sanitária, contribuindo para a melhoria da qualidade e segurança dos produtos alimentícios comercializados, adotando medidas necessárias para evitar ou minimizar riscos à saúde pública. 


\subsubsection{Análise de procedimentos higiênicos}

Na categoria "Análise de procedimentos", das 11 teses e dissertações analisadas, $03(27,27 \%)$ analisaram o procedimento higiênico de mãos, 03 $(27,27 \%)$ analisaram os procedimentos higiênicos do local de preparação de alimentos, $02(18,19 \%)$ analisaram os procedimentos de higiene dos locais de venda de alimentos, 01 (9,09\%) avaliou os procedimentos higiênicos de equipamentos, 01 (9,09\%) avaliou os procedimentos higiênicos de utensílios, e $01(9,09 \%)$ avaliou os procedimentos higiênicos de sanificação de saladas.

Tabela 14 - Distribuição das teses e dissertações, de 1993 a 2007, de acordo com o tema "Análise de procedimentos higiênicos".

\begin{tabular}{l|c|c}
\hline Categorias & $\mathbf{N}$ & $\mathbf{\%}$ \\
\hline Análise de procedimentos higiênicos de mãos & 03 & 27,27 \\
Análise de procedimentos higiênicos/local preparação de alimentos & 03 & 27,27 \\
Análise de procedimentos de higiene / locais de venda de alimentos & 02 & 18,19 \\
Avaliação dos procedimentos higiênicos de equipamentos & 01 & 9,09 \\
Avaliação dos procedimentos higiênicos de utensílios & 01 & 9,09 \\
Avaliação dos procedimentos de sanificação de saladas & 01 & 9,09 \\
\hline Total & $\mathbf{1 1}$ & $\mathbf{1 0 0}$ \\
\hline
\end{tabular}

A contaminação de alimentos pela manipulação inadequada é um problema comum em serviços de alimentação. A ausência de hábitos de higiene primários, tais como banho diário, troca de roupa e lavagem de mãos, associada com a ocorrência de doenças, cortes e infecções na pele, torna o manipulador um potencial disseminador de bactérias como coliformes fecais e Staphylococcus aureus. Os manipuladores portadores de doenças ou mal orientados quanto às práticas de higiene podem contaminar não só os alimentos ao prepará-los, mas também os utensílios de cozinha que utilizam. 
Assim, o estado de saúde e higiene das pessoas que trabalham em estabelecimentos de produtos alimentícios influi diretamente na qualidade dos alimentos (SILVA et al. 2006).

A avaliação da eficiência dos procedimentos de higienização de equipamentos e mãos de funcionários pertencentes a uma unidade de alimentação, um restaurante industrial localizado na região do grande $A B C$, foi o objetivo de ZANON (1999) em sua dissertação de mestrado (anexo 1 99M04). Os resultados das análises demonstraram que nas amostras analisadas, em relação a valores de referência, segundo a Associação Brasileira das Empresas de Refeições Coletivas - ABERC, 48,15\% do total de equipamentos, $69,70 \%$ do total de utensílios e $50 \%$ das áreas de mesas foram consideradas satisfatórias quanto às condições higiênicas adotadas. A autora concluiu que os procedimentos de higienização pretendidos pelo estabelecimento são ideais, contudo as falhas ocorridas foram devidas à inobservância e negligência destes procedimentos por parte dos funcionários.

Em sua dissertação de mestrado (anexo 1 - 02M11), SILVA (2002) verificou as condições dos locais de preparação da merenda escolar sob o ponto de vista higiênico-sanitário, bem como os conhecimentos apresentados pelos manipuladores a respeito da transmissão de doenças através dos alimentos. As unidades escolares visitadas não se encontravam em boas condições sob ponto de vista higiênico sanitário: 42,7\% delas apresentavam áreas de distribuição abertas com presença de pombos, 12,5\% não possuíam telas na área de produção ou armazenamento dos alimentos e foram encontradas falhas na higienização de pisos, paredes, equipamentos e utensílios. Os manipuladores de merenda escolar possuem em geral baixa escolaridade, 62,5\% não apresentam conhecimentos sobre doenças transmitidas por alimentos e 58,3\% afirmaram não possuir o hábito de realizar exame coproparasitológico. Apesar de não apresentaram conhecimentos sobre as DTAs, $56,7 \%$ das pessoas entrevistadas afirmaram 
já ter realizado algum tipo de treinamento na área de alimentos. $\mathrm{O}$ autor concluiu que há risco de transmissão de doenças transmitidas por alimentos nas unidades escolares visitadas, pois estas não se encontravam em boas condições sob ponto de vista higiênico sanitário e os manipuladores não apresentam conhecimentos necessários para a prevenção destas doenças.

Este fato é de fundamental importância para as crianças, visto que as mesmas não possuem, ainda, o sistema imunológico totalmente desenvolvido, sendo mais suscetíveis às doenças transmitidas por alimentos. Diante desta realidade, os cuidados na preparação das refeições nas escolas são de grande relevância (RICHARDS et al., 1993 apud SILVA e SOUZA, 2007).

Os programas de merenda escolar são de importância do ponto de vista da saúde pública e, também, para a Vigilância Sanitária, pois oferecem riscos à população infantil, devido à possibilidade de contaminação e desenvolvimento microbiano em alimentos. Pois, como os produtos que chegam às escolas são previamente preparados, surge a necessidade de uma manipulação adicional. Outro problema é o grande número de refeições servidas, que faz com que seja necessário que as mesmas sejam preparadas com antecedência, o que possibilita um maior período de exposição e, como conseqüência, eventuais contaminações.

RESENDE (2005), em sua tese de doutorado (anexo 1 - 05D45), aplicou um roteiro de entrevista e observou a freqüência com que os clientes que utilizam restaurante tipo self-service higienizam as mãos antes das refeições, no município de Vitória - ES, e constatou que a maioria das pessoas não higienizam as mãos antes das refeições. O autor observou que, apesar de todos os clientes entrevistados reconhecerem a relevância da lavagem de mãos como um fator de proteção da saúde, constata-se, através da observação dos freqüentadores desses restaurantes não é habitual em $71 \%$ dos clientes. 
RESENDE (2005) (anexo 1 - 05D45) conclui que é necessário implementar ações educativas que estimulem a incorporação do hábito de lavar as mãos, inclusive antes das refeições, ao cotidiano das pessoas. Essa promoção deve integrar um processo educativo que envolva toda a sociedade, sem deixar de considerar as diferenças geográficas e socioculturais existentes na população.

Estudar o processo de sanificação de hortaliças no Restaurante Universitário da Escola Superior de Agricultura "Luiz de Queiroz", foi o objetivo de PERDIGÃO (2004), em sua dissertação de mestrado (anexo 1 04M22). A autora analisou as hortaliças recebidas, antes e após a lavagem, antes e após a sanificação e prontas para servir. Todas as amostras analisadas estiveram dentro dos padrões da portaria ANVISA RDC 12/2001. No estudo do processo de sanificação de hortaliças no Restaurante Universitário da Escola Superior de Agricultura "Luiz de Queiroz", foram analisadas as hortaliças recebidas, antes e após a lavagem, antes e após a sanificação e prontas para servir. A autora concluiu que todas as amostras analisadas estiveram dentro dos padrões microbiológicos preconizados pela portaria ANVISA RDC 12/2001.

ALMEIDA (2006), em sua dissertação de mestrado (anexo 1 06M31), coletou amostras de alface, pronta para consumo e sem adição de temperos, de sete restaurantes de padrão self-service, que servem refeição por quilograma e as analisou com o objetivo de conhecer as suas condições sanitárias. Os dados obtidos mostraram que 31 (88,6\%) amostras analisadas apresentaram níveis elevados de coliformes totais. Amostras de hortaliças de mesmo lote foram submetidas a procedimentos higiênicos, utilizando solução clorada e solução de vinagre e posterior análise. Os resultados apresentaram reduções entre $98 \%$ e $99 \%$ nas contagens das bactérias. Com isso, o autor considera a existência de falhas decorrentes de práticas inadequadas de manipulação com ausência ou deficiência de sanificação, sendo necessário treinamento de funcionários e proprietários dos locais, 
visando correção dos problemas, para que se obtenha a qualidade microbiológica adequada do produto e assegure a saúde do consumidor.

Os resultados observados durante a análise das teses e dissertações pertencentes à esta categoria são relevantes à saúde pública e à Vigilância Sanitária por demonstrarem a urgência de maior orientação e fiscalização de estabelecimentos que produzem e comercializam alimentos. É reforçada, também, a necessidade de implantação de um programa de boas práticas de fabricação nestes estabelecimentos para a garantia da segurança alimentar e para a prevenção das doenças veiculadas por alimentos.

Dentre os pontos críticos identificados nas etapas de preparação de alimentos em unidades de alimentação e nutrição, os procedimentos de higienização dos equipamentos e mãos de manipuladores têm fundamental importância (RIBEIRO, 2005b).

O treinamento de técnicas e procedimentos de higienização, em utensílios, equipamentos, ambientes e mãos de manipuladores poderão contribuir para o controle da contaminação cruzada e do risco de toxinfecção alimentar.

O treinamento de manipuladores é elemento essencial para a garantia de alimentos com adequado padrão higiênico-sanitário; visto que, muito comumente, estes profissionais não apresentam qualquer conhecimento na área de alimentação e nutrição (RIBEIRO, 2005c). Às vezes, os cursos e treinamentos destinados aos manipuladores não enfocam a questão da transmissão e a prevenção das doenças transmitidas por alimentos, tornando-se, assim, necessário repensar seus objetivos e inovar as estratégias empregadas a fim de motivar a equipe, promover o conhecimento e a mudanças de atitudes. 


\subsubsection{Análise do processamento mínimo de alimentos}

A análise do processamento mínimo de alimentos foi alvo de pesquisa de 09 teses e dissertações (2,22\%), durante os anos de 1993 a 2007, na Universidade de São Paulo, englobando, principalmente, as alterações físico-químicas, nutricionais, sensoriais e microbiológicas desses alimentos.

Os alimentos minimamente processados podem ser definidos como produtos hortifrutícolas higienizados e embalados que foram submetidos a processos técnicos, preservando suas características sensoriais, naturais, tornando-os prontos para o consumo in natura ou para preparo culinário (SANTAELLA et al., 2006).

NARDIN (1999), em sua dissertação de mestrado (anexo 1 - 99M07), avaliou a conservação de cogumelos comestíveis por acidificação e processamento térmico e por desidratação. Os três métodos mostraram ser eficientes na armazenagem e no transporte, não oferecem riscos à saúde do consumidor e pode ser utilizado por pequenas indústrias, pois utiliza equipamentos de baixo custo e pouca demanda de energia.

A estabilidade de "Minced Fish", produzidos em condições industriais com espécies de peixes de água-doce amazônica, durante o congelamento foi estudada por JESUS (1999), em sua tese de doutorado (anexo 1 99D17). O autor verificou que as espécies estudadas mantiveram-se em condições de consumo por 150 dias de estocagem entre -18 e $36^{\circ} \mathrm{C}$.

SOCCOL (2002), em sua dissertação de mestrado (anexo 1 - 03M04), verificou que durante o período de armazenamento da tilápia minimamente processada não se detectou a presença de Salmonella, Clostridium sulfitoredutores e Escherichia coli. A autora observou ainda que os tratamentos a 
vácuo, associados ou não ao ácido acético, inibiram o desenvolvimento de S. aureus, coliformes totais e psicrotróficos proporcionando uma vida útil de 20 dias. O embalamento a vácuo associado ao ácido acético foi o tratamento que manteve as características físico-químicas, microbiológicas e sensoriais mais estáveis.

VITTI (2003), em sua dissertação de mestrado (anexo 1 - 03M17) determinou respostas fisiológicas, bioquímicas e microbiológicas associadas ao processamento mínimo de beterraba e desenvolveu um fluxograma de preparo específico para esta hortaliça, visando menor perda de qualidade e máxima capacidade de conservação. $O$ autor verificou que o ácido cítrico reduziu a atividade respiratória, o extravasamento e a degradação dos pigmentos de betalaínas nas beterrabas minimamente processadas. $\mathrm{O}$ tempo de sanitização de 3 minutos é o mais apropriado para manutenção da qualidade. A sanitização apenas após a pelagem é a mais apropriada para manutenção da qualidade, pois reduz a perda de pigmentos e garante um produto com padrões microbiológicos abaixo dos limites permitidos pela RDC 12/2001, além de evitar o desperdício de cloro. O autor concluiu que, pelo novo fluxograma de preparo, as beterrabas minimamente processadas têm um período de comercialização viável por 10 dias. O novo fluxograma desenvolvido é mais indicado para manutenção da qualidade por reduzir perda de pigmentos, reduzir a taxa respiratória e garantir a segurança alimentar do produto.

Com as novas tecnologias de processamento e conservação de hortaliças e frutas, a vida de prateleira dos alimentos frescos é prolongada, o que possibilita a comercialização em áreas mais distantes dos pontos de produção e para um maior número de consumidores. O controle pelas agências governamentais é dificultado pela capacidade da indústria incorporar técnicas de produção e novos produtos em uma velocidade muito acima da capacidade dos órgãos reguladores legislar ou normatizar sobre o tema (LUCCHESI, 2001). 
Foram observadas inovações tecnológicas nessa área, sendo pesquisadas pelos pós-graduandos, especialmente nos últimos anos, por exemplo, o uso de filmes e coberturas comestíveis em alimentos. Os filmes e coberturas comestíveis elaborados a partir de polissacarídeos ou proteínas podem satisfatoriamente ser empregados como revestimento protetor sobre frutos fatiados ou in natura. As mais importantes funções dessas coberturas são: o controle sobre a transferência de massa, proteção mecânica durante o transporte e a preservação por um maior período do aspecto visual, gerando assim um apelo sensorial. De um modo geral, tanto filmes hidrofílicos quanto hidrofóbicos atuam razoavelmente na preservação de frutos fatiados, reduzindo sua desidratação $e$ inibindo $o$ ataque por microrganismos. Em alguns tipos de produtos, certamente, o emprego de coberturas poderá potencialmente vir a substituir as embalagens comerciais, ou reduzir o emprego de condições favoráveis de conservação como refrigeração ou atmosferas controladas, reduzindo os custos de preservação (ASSIS et al., 2008).

Os alimentos processados e os produtos in natura são artigos importantes no mercado internacional. Muitos países, inclusive o Brasil, exportam parte de sua produção para gerar recursos. Este mercado pode ser ameaçado por restrições impostas pelos países importadores, relativas à segurança do produto (DESTRO, 2002).

SANTAELLA (2007), em sua tese de doutorado (anexo 1 - 07D24), cita que a produção de alimentos minimamente processados deverá se adaptar ao mercado para expandir ainda mais sua participação para ganhar em escala, mas para isto, além do preço, precisará conquistar a confiança do consumidor com relação aos atributos de qualidade e higiene.

O processamento mínimo de alimentos é um assunto contemporâneo. Com a crescente preocupação dos consumidores por alimentos saudáveis, a 
disposição no mercado de alimentos minimamente processados atende à demanda por produtos práticos e frescos decorrentes de alterações como a urbanização, a entrada massiva da mulher no mercado de trabalho e a mudança no estilo de vida dos consumidores (SANTAELLA, 2007) (anexo 1 - 07D24). O aumento no consumo desses alimentos pode implicar em um risco diferenciado, pois um possível surto passa ter proporções e características diferentes, podendo afetar grande parcela da população.

Com isso, mostra-se necessária e pontual a preocupação da Universidade em pesquisar essas novas tecnológicas e, também, a consideração dessas novas tecnologias pelos profissionais de Vigilância Sanitária, para que tenham uma constante capacitação, a fim de que suas práticas sejam coerentes, atuando na prevenção de riscos à saúde da população. 


\subsubsection{Pesquisa de consumo alimentar}

Na categoria "Pesquisa de consumo alimentar" foram analisadas 09 teses e dissertações $(2,22 \%)$ que realizaram pesquisas de satisfação do consumidor, pesquisas de opinião acerca de alimentos e pesquisas para avaliar a mudança nos hábitos alimentares da população.

VICTALIANO (2004), em sua dissertação de mestrado (anexo 1 04M14), realizou uma pesquisa com o objetivo de avaliar a satisfação e aceitação do produto pelos consumidores. A pesquisa foi aplicada em três produtos alimentícios recém lançados, o Risoto de Queijo Parmesão, o Risoto de Funghi e Champignon e o Risoto de Carne Desfiada com Abóbora, produzidos por uma grande empresa brasileira. Os resultados mostraram que os consumidores ficaram satisfeitos com estes produtos mas, no entanto, é importante ressaltar que os resultados aqui encontrados refletem uma amostragem de consumidores, e para validação de alterações em características de qualidade faz-se necessário construção e testes exaustivos de protótipos junto aos consumidores.

MENDES (2002), em sua tese de doutorado (anexo 1 - 02D35), investigou os possíveis determinantes da disposição de pagar (DDP) mais por produtos hortifrutícolas in natura sem agrotóxicos (HSA) de uma amostra aleatória de 314 consumidores, no município de Piracicaba, no Estado de São Paulo. Os resultados mostraram que $87 \%$ dos entrevistados sabiam que produtos hortifrutícolas podem estar contaminados com resíduos de agrotóxicos. Uma das principais fontes dessa informação, apontada pelos entrevistados, foi a mídia. Desta forma, esta última poderia exercer um papel essencial em programas orientados aos consumidores, alertando-os com relação ao consumo de alimentos seguros e estimulando sua comercialização atuando, na melhoria da saúde pública. Os resultados 
mostraram que, dentre as variáveis explicativas da DDP, o 'preço', 'grupo de risco', 'testado pelo governo' e 'atitude' constituíram fatores significativos na explicação da disposição de pagar mais por HSA. Assim, a importância do preço e a escolha do governo como órgão certificador aumentam a probabilidade de os consumidores pagarem mais por HSA. Por outro lado, a existência de pessoas consideradas mais vulneráveis tais como crianças, gestantes, idosos e pessoas com doença crônica ('grupo de risco') na família e a atitude dos entrevistados em prol de políticas mais restritivas com respeito aos agrotóxicos aumentam a probabilidade de os consumidores pagarem mais por HSA. Com relação a esta última, os resultados mostraram que para $92 \%$ dos consumidores, todos os agrotóxicos deveriam ser definitivamente proibidos (banidos) ou os que não são seguros deveriam ser proibidos e os restantes deveriam sofrer maiores restrições.

O perfil, a opinião e as atitudes dos consumidores em relação aos alimentos orgânicos foram pesquisados por BORGUINI (2003), em sua dissertação de mestrado (anexo 1 - 03M11). A autora constatou que o fato de os alimentos serem identificados como livres de pesticidas foi considerada, pelos consumidores, como uma característica muito importante. Com relação às restrições, registradas pelos consumidores, ao consumo de alimentos orgânicos, merece destaque as citações relativas aos preços elevados e a disponibilidade limitada desse tipo de alimento.

Ainda nesse âmbito, houveram trabalhos voltados ao comércio de comida de rua que, além de abordar essas mudanças de hábitos alimentares, atentam para o risco de consumir alimentos oriundos desse tipo de serviço, como os de: LUCCA (2000) (anexo 1 - 00M23), HANASHIRO (2002) (anexo 1 - 02M26), PEDRO (2003) (anexo 1 - 03M01) e PEREIRA (2004) (anexo 1 - 04M21). 
A indústria de comida de rua tem se consolidado por satisfazer as necessidades - especialmente da população de baixa renda - de obtenção de alimentos rápidos, de baixo custo e em local próximo ao trabalho (LUCCA e TORRES, 2002) e, também, por ser uma estratégia de sobrevivência para grupos socialmente excluídos, principalmente nos países em desenvolvimento, representando a um só tempo, uma oportunidade de trabalho e renda e uma alternativa para atender necessidades alimentares de populações urbanas (CARDOSO et al., 2006). Ou seja, o comércio de alimentos de rua apresenta aspectos positivos devido a sua importância socioeconômica, cultural e nutricional; e negativas no tocante às questões higiênico-sanitárias (LUCCA e TORRES, 2002), representando uma ameaça à saúde do consumidor, devido a técnicas de higiene e manipulação de alimentos inadequadas (LUCCA e TORRES, 2002; CARDOSO et al., 2006; SIQUEIRA et al., 2006).

As mudanças no estilo alimentar e a vida sedentária interferem diretamente no perfil nutricional da população, tornando-a mais suscetível às doenças crônicas não transmissíveis.

A modificação nas práticas alimentares brasileiras vem acompanhada de mudanças negativas sob o aspecto nutricional - a substituição dos grãos e cereais por alimentos de origem animal, gorduras, açúcares, alimentos industrializados, e que são de uma maneira geral pobres em carboidratos complexos e fibras (MINISTÉRIO DA SAÚDE, 2005). Os novos padrões de trabalho e lazer também contribuem negativamente, pois propiciam o baixo gasto energético, o sobrepeso e o sedentarismo que irão levar ao aumento na pressão arterial, colesterol e diabetes, que por sua vez vão ocasionar as doenças no coração, rins, derrames, câncer e outras doenças nãotransmissíveis no país (BANCO MUNDIAL 2005).

A garantia da qualidade intrínseca e a segurança dos alimentos, que satisfaçam às necessidades dos consumidores é o objetivo das indústrias, 
do governo e dos agentes de padronização e certificação do comércio internacional. Com a perspectiva de o mercado tornar-se cada vez mais competitivo, faz-se imprescindível que as empresas conheçam melhor o perfil de seus consumidores, seus desejos, e, principalmente, se estão satisfeitos com o que receberam. Este contato, estabelecido entre o consumidor, a empresa e seus produtos pode fortalecer e estreitar as relações entre ambos.

O aumento da população mundial pressionando a demanda por alimentos faz surgir, no admirável mundo da engenharia genética como da pesquisa agropecuária tradicional, uma enorme necessidade de produção de alimentos. Contudo, é necessário que todo esse avanço tecnológico esteja associado a uma produção que garanta o bem-estar das pessoas, começando pela segurança dos alimentos produzidos, seja através de uma agricultura sustentável ou processados em laboratórios. A prosperidade de um país também é garantida quando ele é capaz de produzir os alimentos necessários para nutrir seus habitantes, mas sem que isso implique em sérios e, principalmente, desconhecidos riscos de saúde pública MENDES (2002) (anexo 1 - 02D35). 


\subsubsection{Análise de alimentos transgênicos}

Na categoria "Análise de alimentos transgênicos" foram analisadas 08 teses e dissertações (1,98\%).

Transgênico pode ser definido como todo organismo que recebe um gene de um outro, podendo ser de espécies diferentes ou não, sem o emprego de um processo de reprodução normal. Esse gene transferido pode conferir suas propriedades ao organismo que o recebe (GUERRANTE, 2003; LAJOLO e NUTTI, 2003).

A tecnologia dos organismos geneticamente modificados (OGMs), os transgênicos, é um conhecimento científico recente, que data de 1973. A partir deste marco, tornou-se possível, através de um conjunto de técnicas, intercambiar genes entre espécies vivas que nunca se relacionaram de maneira natural. A introdução, eliminação e/ou remanejamento desses genes podem alterar o mecanismo de produção de proteínas no organismo geneticamente modificado, fazendo com que ele passe a sintetizar novas substâncias, deixe de produzir proteínas que, antes da modificação genética, eram expressas; ou, até mesmo, sintetize maiores quantidades de substâncias já presentes nesse organismo. Os métodos comumente empregados para detecção de OGMs são os métodos imunológicos, como o teste ELISA e a técnica de amplificação por PCR (GUERRANTE, 2003; LAJOLO e NUTTI, 2003).

No Brasil, somente em 1996, foram autorizados os primeiros plantios experimentais de sementes modificadas. As notícias sobre transgênicos só começaram a aparecer na mídia em 1998, com a suspensão do plantio comercial da soja modificada, produzida pela Monsanto. Os anos seguintes 
foram marcados por intensa disputa judicial em torno da liberação comercial do plantio de OGMs. E essas discussões se intensificaram, à medida que o Brasil foi se transformando em peça-chave no comércio mundial de sementes, já que era o único grande fornecedor que apresentava culturas isentas de modificação (GUERRANTE, 2003; LAJOLO e NUTTI, 2003).

Como o cultivo de transgênicos foi proibido em nosso país até março de 2005, apenas o cultivo e a comercialização da soja transgênica era permitido desde 2003, por meio das seguintes iniciativas: Medida Provisória 113, de março de 2003, Medida Provisória 131, de setembro de 2003; Lei nº. 10.814 , de 15 de dezembro de 2003 , que estabelecia normas para o plantio e a comercialização da soja geneticamente modificada da safra de 2004 , Medida Provisória 223, de outubro de 2004; da Lei no. 11.092, de 12 de janeiro de 2005, que estabelecia normas para o plantio e comercialização da produção de soja geneticamente modificada da safra de 2005 (MENDONÇA, 2005) (anexo 1 - 05M09).

Em março de 2005, a produção e a venda de transgênicos passaram a ser regulamentadas, posteriormente à aprovação e sanção do projeto de Lei de Biossegurança que, além de regulamentar a produção e a venda de transgênicos, também regulamentou as pesquisas com células-tronco humanas. Instituições, empresas e agricultores que desejem realizar atividades com organismos geneticamente modificados devem, de acordo como previsto na Lei de Biossegurança (Lei $n^{\circ}$ 11.105) requerer prévia autorização junto à Comissão Técnica Nacional de Biossegurança (CTNBio) (MENDONÇA, 2005) (anexo 1 - 05M09).

Dentre as pesquisas relacionadas aos alimentos transgênicos se destaca a pesquisa realizada por CHARANEK (2006), em sua tese de doutorado (anexo1 - 06D07) na qual houve uma investigação da composição 
total dos nutrientes e alguns contaminantes presentes em amostras de soja, transgênicas e convencionais, provenientes de diferentes regiões do Brasil. O autor observou que os testes de biodisponibilidade de nutrientes realizados in vitro mostraram que a modificação genética não altera a disponibilidade dos elementos presentes na soja, nem em sua disponibilidade nutricional.

GIORA (2004), em sua dissertação de mestrado (anexo 1 - 04M32), realizou uma avaliação in vivo da qualidade protéica da soja geneticamente modificada e observou que a ingestão da variedade geneticamente modificada não causou diferença significativa no desenvolvimento dos animais entre as três amostras de soja ensaiadas e tampouco foram observados efeitos adversos em órgãos dos animais e nos parâmetros químicos analisados.

Em sua dissertação de mestrado (anexo 1 - 05M08), CINTRA (2005) estudou o efeito do consumo de soja geneticamente modificada em parâmetros nutricionais e hematológicos em ratos em crescimento. A autora constatou que não houve diferença estatística nos parâmetros plasmáticos estudados, bem como nos resultados hematológicos sugerindo que o consumo de soja, convencional ou geneticamente modificada, não altera o estado nutricional dos animais.

MENDONÇA (2005), em sua dissertação de mestrado (anexo 1 05M09), avaliou o nível de informação de professores e alunos de cursos técnicos em nutrição, mantidos por escolas públicas e situados em diferentes regiões e municípios do Estado de São Paulo. A maioria dos professores registrou respostas, consideradas pertinentes, às questões relacionadas ao tema "transgênicos", embora se esperasse que as citações envolvessem o uso de termos mais precisos, visto os integrantes da amostra serem graduados, e, em grande parte, pós-graduados, em diversas áreas afins das ciências biológicas. A maioria dos alunos também respondeu às 
referidas questões, embora, também, de maneira superficial. Substancial parcela dos professores (62\%) não soube afirmar se alimentos/produtos transgênicos são benéficos ou maléficos ao homem, situação esta já esperada, em virtude da escassez de informações sobre as conseqüências que o consumo destes alimentos podem trazer ao homem. A maioria dos entrevistados apóia pesquisas que envolvam a análise de temas relacionados à transgenia, além de reconhecer a necessidade da rotulagem de alimentos transgênicos. A autora conclui que o maior volume de investimentos em educação, entre outras iniciativas, poderia contribuir para a formação de professores e alunos, auxiliando-os a avaliar, criticamente, questões relativamente novas, como a transgenia.

À medida que a discussão sobre os alimentos modificados e sobre as questões de comércio internacional relacionadas à biotecnologia se intensifica, surge a crescente tendência de distinguir, pela rotulagem tais alimentos, daqueles que não são modificados.

Em vários países, a legislação para a rotulagem destes alimentos estabelece limites permissíveis de OGMs (chamados threshold levels). Logo, alimentos que contenham ingredientes geneticamente modificados em níveis acima do permitido devem ser rotulados como "geneticamente modificados" (MAYER e STIRLING, 2002).

Nos Estados Unidos não existe nenhum requerimento obrigatório para a rotulagem, pois, segundo a FDA (Food and Drug Administration), os alimentos geneticamente modificados são substancialmente equivalentes aos seus análogos convencionais, não requerendo nenhum tipo de rotulagem específica, a não ser nos casos em que o conteúdo nutricional tenha sido alterado ou o produto contenha alérgenos conhecidos (LAJOLO e NUTTI, 2003). 
No Brasil, o limite permitido é de $1 \%$, e tanto os produtos embalados, como os vendidos a granel, que contenham ou são produzidos a partir de OGMs, deverão ser rotulados, e o consumidor deverá ser informado sobre a espécie doadora do gene no local reservado para a identificação dos ingredientes, de acordo com o Decreto 4680, de 24 de abril de 2003 (LAJOLO e NUTTI, 2003).

O emprego de alimentos transgênicos ou organismos geneticamente modificados tem divido opiniões e gerado muita polêmica, até mesmo dentro da Vigilância Sanitária. Por um lado, estão organizações não governamentais, como a ambientalista Greenpeace, que se posicionam contra o emprego desta tecnologia, alegando riscos ao meio ambiente e à saúde humana. Em situação oposta, encontram-se grupos de produtores agrícolas que acreditam que a adoção da técnica possibilita maior produtividade, além de empresas, como é o caso da multinacional Monsanto, que desenvolve sementes transgênicas e têm interesse em conquistar e ampliar mercados para seus produtos. Também congrega esse grupo parcela da comunidade científica, que acredita que a transgenia possa melhorar a qualidade da produção dos alimentos. Há, também, políticos e grupos da comunidade científica que, embora reconheçam os benefícios desta tecnologia, acreditam que seja necessária a implementação de expressivo volume de pesquisas, para a obtenção de comprovação científica, atestando que a técnica não traz riscos à saúde e ao meio ambiente (MENDONÇA, 2005) (anexo 1 - 05M09).

Além do fato de os alimentos transgênicos serem iniciativas recentes, a existência de debates muitas vezes regados de conflitos tem contribuído para gerar insegurança quanto aos seus riscos prováveis e hipotéticos, relacionados à saúde e ao meio ambiente. No entanto, cabe ressaltar que não se dispõe de tecnologia com risco zero e, portanto, o desafio é avaliar, por meio de método científico a probabilidade de tais ocorrências (MENDONÇA, 2005) (anexo 1 - 05M09). 
As técnicas de produção de OGMs têm potenciais de aplicação que vão da produção de alimentos até áreas da medicina. Estas aplicações, que parecem fascinar aqueles que acreditam num futuro revolucionado pela ciência, trazem, também, preocupações para aqueles que temem suas conseqüências, que podem ser imprevisíveis ou irreversíveis (GUERRANTE, 2003).

Embora, até o presente momento, não exista nenhuma constatação de que produtos transgênicos já tenham provocado algum impacto negativo, a rejeição por estes alimentos merece consideração, pois, ainda há desconhecimento muito forte por parte do consumidor do real conceito das novas tecnologias. Pois, é sabido que não é só a legislação que garante a segurança. A informação, a conscientização e o amadurecimento do consumidor são fatores relevantes para que a população exerça o seu papel - o controle social (RODRIGUES, 2008).

Pode-se dizer que o investimento em informação poderia esclarecer de maneira mais consistente os consumidores, auxiliando-os a avaliar, tendo por base, dados técnicos, questões relativamente novas, como a transgenia e biotecnologia, de forma geral. Destaca-se nesta questão, a importância assumida pelos grandes veículos de comunicação - televisão, jornais, revistas, que alcançam distintos estratos da população e, portanto, poderiam fornecer conhecimentos técnicos e atuais com agilidade.

VILLARES (2004), em sua dissertação de mestrado (anexo 1 04M12), cita que o Direito Ambiental serve à regulação da biotecnologia e à efetivação do direito fundamental ao meio ambiente. Dos princípios do Direito Ambiental relacionados com a biotecnologia, que definem a lógica e a racionalidade da regulamentação, decorrem os direitos à informação e 
participação, fundamentos da rotulagem dos produtos fabricados com organismos geneticamente modificados, grande ponto de intersecção entre o Direito Ambiental e o Direito do Consumidor, disciplinas cujo encontro se mostra inevitável num Estado democrático em que se reconheça o papel do Direito na definição do modelo de organização social, já que a rotulagem dos alimentos transgênicos é medida fundamental de proteção do consumidor, inscrita na legislação ambiental e consumerística nacional, pois informa os riscos corridos e garante o direito do consumidor de participar e decidir sobre os modos de produção social e econômica.

Vale lembrar que a adoção de recomendações, legislações, códigos ou protocolos de conduta, não garantem por si só a segurança. Deve-se dispor de mecanismos para avaliar a segurança, identificando perigos e medidas preventivas, tais como monitoramento apropriado, pesquisa e troca de informações, as quais contribuem para a melhor aplicação da biotecnologia (RODRIGUES, 2008). 


\subsubsection{Análise da rotulagem de alimentos}

Cinco teses e dissertações analisadas (1,23\%) foram classificadas na categoria "Análise da rotulagem de alimentos".

Esse assunto passou a se tornar foco de pesquisa a partir de 2001, com a Resolução de Diretoria Colegiada RDC n. ${ }^{0}$ 40, de 21 de março de 2001, que tornou a rotulagem nutricional obrigatória, disseminando a presença de tabelas com informações nutricionais em embalagens. Essa resolução foi, posteriormente, revogada pela RDC n. ${ }^{\circ} 360$, de 23 de dezembro de 2003. Através dessa resolução, os valores de nutrientes podem ser provenientes de análises ou calculados a partir de valores encontrados em tabelas de composição nacionais ou estrangeiras.

Em sua dissertação de mestrado, RATTO (2005) (anexo 1 - 05M03) comparou as informações nutricionais levantadas em embalagens de barras de cereais comercializadas na grande São Paulo com os valores destes produtos presentes na Tabela Brasileira de Composição de Alimentos (TBCA-USP), que foi utilizada como parâmetro em função da credibilidade das informações sobre valores de nutrientes. A autora verificou possíveis erros nos valores de nutrientes impressos nos rótulos, servindo de referência, em algumas situações, para questionar a qualidade dos dados destes nutrientes na rotulagem nutricional de barras de cereais, pois houve uma expressiva variabilidade observada nos teores de nutrientes das diferentes barras de cereais.

BARRERA (2004), em sua dissertação de mestrado (anexo 1 04M20), analisou a rotulagem dos produtos a base de creatina oferecidos pelo mercado, por meio de um modelo de monitoramento que decompõe as normas para rotulagem de alimentos especiais para praticantes de 
atividades físicas. A autora constatou que, de um modo geral, existe um alto grau de obediência às normas, principalmente em função do desejo das empresas em terem este produto aceito como alimento, se aproveitando de uma indefinição legal. Porém, foi observado que informações importantes referentes à orientação para o consumo, e contra indicações não aparecem de forma adequada, até porque a própria legislação não contempla estes itens. Atualmente sendo subordinada a uma legislação específica para medicamentos, sua venda não esta vinculada à obrigatoriedade da apresentação de receita médica, o que indica que o produto continuará sendo vendido livremente. Assim a rotulagem continua desempenhando papel fundamental, representando um grande beneficio ao consumidor quando usada de forma adequada, pois suas informações têm uma importante função educativa e de orientação, devendo haver uma preocupação por parte dos legisladores no sentido de aprimorar a legislação de produtos com estas características.

A avaliação crítica da legislação brasileira sobre rotulagem nutricional e a sua comparação com a de outros paises, como Canadá, EUA, União Européia e ás Normas do Codex Alimentarius, foi objetivo de FERREIRA (2004) em sua dissertação de mestrado (anexo 1 - 04M19). A autora concluiu que a legislação brasileira não difere muito da internacional, A comunidade Européia e as Normas do Codex Alimentarius estabelecem que a informação nutricional deve ser por $100 \mathrm{~g}$ ou $100 \mathrm{~mL}$ de alimento, tem a vantagem de não subestimar sistematicamente a real contribuição de certos nutrientes que estão presentes nos alimentos em baixa concentração e por isso não são declarados na porção de referência. Ademais um levantamento foi conduzido através da avaliação de 460 rótulos de alimentos industrializados no Brasil e o resultado mostrou que $47 \%$ estavam irregulares e $41 \%$ apresentavam informações contraditórias. A autora recomenda que o governo incentive as indústrias a manterem a declaração de ferro, cálcio e colesterol nos rótulos de alimentos. De posse da rotulagem nutricional, é aconselhável esclarecer à população a importância da 
informação nutricional e como utilizá-la em benefício da saúde do consumidor.

A rotulagem nutricional dos alimentos é importante para a promoção de hábitos alimentares, pois tem com objetivo informar ao consumidor sobre a composição do alimento e auxiliar na seleção e aquisição do mesmo, favorecendo escolhas que promovam o consumo de uma dieta mais equilibrada e saudável (MENDONÇA e ARAÚJO, 2006). Pois, as informações nutricionais em embalagens são um canal em potencial para educar o consumidor a respeito da adequação do produto à sua saúde, como parte integrante de um programa de educação nutricional abrangente (RATTO, 2005) (anexo 1 - 05M03).

A disponibilidade e a diversidade de alimentos industrializados nas prateleiras dos supermercados é cada vez maior, face à demanda crescente do mercado (GRACIANO, 2000 apud PENHA FILHO et al., 2006), e a ausência de informações e/ou falhas nas Tabelas de Valor Nutricional que constam nos rótulos dos alimentos pode induzir a erros de interpretação pelo público consumidor.

Nesse âmbito, destaca-se a importância da Vigilância Sanitária nesse aspecto, a fim de realizar uma fiscalização mais eficaz para reforçar o compromisso dos fabricantes, visto que ainda não há um compromisso ético de algumas empresas, bem como a promoção de programas de educação nutricional com o objetivo de informar o consumidor a respeito da importância das informações contidas nos rótulos dos alimentos. 


\subsubsection{Avaliação de surtos alimentares}

Quatro teses e dissertações (0,99\%) foram analisadas e classificadas na categoria "Avaliação de surtos alimentares".

Surtos de doenças transmitidas por alimentos, são definidos pelo aparecimento de, pelo menos, dois casos similares de uma sintomatologia, em geral gastrintestinal, resultantes de uma mesma origem alimentar (LEITE et al., 2006), e são um grande problema de saúde pública.

COLOMBARI (2002), em sua dissertação de mestrado (anexo 1 02M04) estudou um surto de intoxicação estafilocócica ocorrido em Brodowski, SP, em 1998, através da caracterização fenotípica (fagotipagem e antibiograma) e genotípica (Random Amplified Polymorphism DNA-RAPD) de cepas de Staphylococcus aureus isoladas dos alimentos e de materiais clínicos dos manipuladores envolvidos. A autora concluiu que, pela combinação dos métodos fenotípicos e genotípicos empregados, constatouse que os manipuladores $\mathrm{A}, \mathrm{B}, \mathrm{H}$, e I podem ter sido responsáveis pela disseminação de $S$. aureus enterotoxigênicos nos alimentos desencadeadores do surto de intoxicação estafilocócica ocorrido na cidade.

LIRA (2005), em sua dissertação de mestrado (anexo 1 - 05M05), realizou um levantamento de doenças transmitidas por alimentos no município de Guarapuava, dos anos de 1999 a 2003, identificando características de gênero, faixa etária, causas e contexto das ocorrências. A autora concluiu que as ocorrências de DTA's no município de Guarapuava caracterizaram-se por um predomínio em pessoas do sexo masculino, tendo como causa principal as intoxicações por alimentos sólidos suspeitos, como saladas e grãos. Pelas características dos sintomas e do tempo transcorrido 
entre o acidente e sintomatologia descritos nas fichas, talvez os casos estejam relacionadas à bactérias do tipo Clostridium perfringens e Salmonella sp, não comprovados devido à ausência de exames de laboratório. Os meses em que ocorreram a maior parte dos casos não indicam padrões de sazonalidade, nem mesmo em relação a festividades. Os resultados também revelaram um predomínio de ocorrência de casos em adultos jovens, do sexo masculino, e freqüentemente em restaurantes. A investigação também revelou uma inadequação no preenchimento das fichas, o que exigiu a busca de informações em diversos modelos de fichas para complementar todos os dados. A autora conclui que é de fundamental importância para análises em saúde o correto preenchimento de todos os campos e dados das fichas utilizadas para a investigação de DTA's, aliado à integração das ações de Vigilância à Saúde, subdivididas em Epidemiológica, Sanitária e Ambiental.

As doenças transmitidas por alimentos são bastante comuns em nosso meio e representam, atualmente, um grave problema para a saúde pública. Embora a maioria dos casos sejam considerados de nível leve a moderado, algumas infecções mais graves podem ocasionar seqüelas e até mesmo provocar óbitos, além dos dispêndios hospitalares, do afastamento das atividades profissionais e escolares. Estudos relacionados a esse tema são necessários e de relevância, não apenas para o conhecimento da doença e do ambiente, mas para a Vigilância Sanitária, a fim de aprimorar a fiscalização, a segurança alimentar e as práticas de manipulação e comércio de alimentos para a população. 


\subsubsection{Análise da oxidação lipídica em alimentos}

A análise da oxidação lipídica em alimentos, foi tema de pesquisa entre $04(0,99 \%)$ teses e dissertações analisadas.

As gorduras podem ser transformadas por reações de hidrólise, oxidação e outros processos, em compostos que acarretam modificações agradáveis ou não no aroma do alimento. A deterioração da gordura é conhecida como rancificação. Existem dois tipos de rancificação: a hidrolítica, geralmente de origem enzimática podendo ser causada por microrganismos, e a oxidativa, que não depende da ação de microrganismos. A rancificação oxidativa produz substâncias com aroma pronunciado e desagradável devido à decomposição dos hidroperóxidos em compostos carbonílicos (misturas de cetonas e aldeídos saturados e insaturados) (LANDGRAF, 2002).

FERRARI (1998), em sua dissertação de mestrado (anexo 1 - 98M02) avaliou a oxidação lipídica e verificou possíveis correlações entre valores de ácido tiobarbitúrico (TBA) e fatores associados à qualidade de alimentos, como o teor de gordura, o potencial de óxido-redução $(\mathrm{EH})$, o potencial hidrogeniônico $(\mathrm{pH})$, o teor de umidade e a atividade água ( $\mathrm{Aa}$ ), de salsichas comercializadas em sacolões da prefeitura do município de São Paulo. Após análise baseada nos vários fatores, o autor concluiu que todas as amostras analisadas estavam fora dos padrões higiênico-sanitários de $\mathrm{Aa}$ e $\mathrm{pH}$ e que os teores de umidade encontrados foram muitos superiores, o que teria contribuído na oxidação lipídica das amostras de salsicha analisadas.

O aumento da utilização de embalagens do tipo politereftalato de etila - PET- nos últimos anos tem feito com que produtores de óleo se preocupem 
com a oxidação de seu produto. Com isso, OLIVEIRA (2003), em sua dissertação de mestrado (anexo 1 -03M06), realizou testes de oxidação acelerada em óleos de milho e canola isentos de antioxidante e ácido cítrico, que foram adicionados de diferentes concentrações de tero-butil-hidroquinona (TBHQ), um aditivo para alimentos. A partir dos resultados de índice de peróxido obtidos nos óleos com as diferentes concentrações de TBHQ no teste em estufa, o autor concluiu que ambos os óleos foram armazenados em frascos PET por 6 meses em condições satisfatórias.

As análises de oxidação lipídica são importantes para a Vigilância Sanitária pelo fato da rancificação oxidativa ser um indicador de deterioração de alimentos. Visto que é de interesse oferecer à população alimentos seguros, e também de qualidade. 


\subsubsection{Análise do reuso da água}

Houveram 02 dissertações analisadas $(0,49 \%)$ na categoria "Reuso da Água".

No Brasil e no mundo, tem sido observada uma freqüente diminuição na natureza, da oferta de água em condições adequadas para uso, devido à crescente demanda para as mais variadas atividades, como o abastecimento público, uso industrial e para a agricultura (MATSUMURA, 2007) (anexo 1 07M04).

A qualidade da água superficial disponível tem sido degradada devido aos lançamentos indevidos de poluentes, tanto de cargas concentradas como difusas, sendo que os tratamentos necessários para a utilização da água têm sido cada vez mais dispendiosos, exigindo tecnologias mais complexas (MATSUMURA, 2007) (anexo 1 - 07M04).

Com base nessa realidade, FRANCO (2007) abordou, em sua dissertação de mestrado (anexo 1 - 07M09), a metodologia APPCC como ferramenta para reuso de água em uma indústria. O autor fez uma análise dos principais processos produtivos, para a identificação da demanda de água e, consequentemente, das áreas com maior potencial para aplicação de alternativas para reuso da água. Nesse estudo, foi apenas desenvolvido o método sem a aplicação.

Já no caso de MATSUMURA (2007), em sua dissertação de mestrado (anexo 1 - 07M04), foi desenvolvida uma metodologia para reuso de água em uma unidade de processamento de frangos, através da identificação de falhas operacionais, da proposta de melhorias e identificação de setores e locais com maior consumo de água e geração de efluentes. A autora obteve 
uma redução global no consumo de água de 14,20\% e um aumento na produção de 17,46\%. MATSUMURA (2007) ainda cita que, existem regulamentações internacionais sobre reuso de água, mas, no Brasil, esse tema ainda é recente e que no momento há somente uma legislação dando diretrizes a esse recurso.

A melhoria da qualidade de vida da população está fortemente condicionada à cobertura e à qualidade dos serviços de abastecimento de água e esgotamento sanitário disponíveis. Uma gestão eficiente dos recursos hídricos deve estar baseada em políticas e estratégias claras, além de mecanismos e ferramentas efetivos para proteger da poluição os recursos hídricos existentes. Deve também garantir que a água seja utilizada da melhor forma, limitando os conflitos decorrentes do seu uso já que os recursos hídricos constituem-se em um importante aliado para a implantação de ações de saúde e ambiente (MIRANDA, 2005).

Com relação ao reúso de água, o Conselho Nacional de Recursos Hídricos do Ministério do Meio Ambiente, através da Resolução nº. 54, de 28 de novembro de 2005, estabeleceu modalidades, diretrizes e critérios gerais que regulamentam e estimulam a sua prática para fins não potáveis em todo o território nacional. Resolve também que "deverão ser incentivados e promovidos programas de capacitação, mobilização social e informação quanto à sustentabilidade do reúso, em especial os aspectos sanitários e ambientais".

MATSUMURA (2007) (anexo 1 - 07M04) cita que, infelizmente, não existem programas de incentivos às indústrias para que essas implantem sistemas de conservação, minimização e reúso de água. Sem esses instrumentos, a prática não é interessante economicamente, e que existem tecnologias que permitem a prática do reúso de água potável, mas no Brasil ainda são caras, o que acaba inviabilizando sua aplicação. 
Apesar do grande potencial do reúso de água, esse tema é uma preocupação relativamente recente no meio industrial. Esse tema ainda merece a realização de estudos e pesquisas e sua ampla divulgação, visto que sua importância é grande, não só para as indústrias, mas também para a sociedade. Um empecilho, segundo FRANCO (2007) (anexo 1 - 07M09) é o fato de que as indústrias de alimentos que estão planejando a implantação do reúso de água apoiados pela ferramenta APPCC armazenam as suas informações na própria empresa, e não as divulgam facilmente. 


\subsubsection{Análise dos aspectos conceituais e operacionais da Vigilância Sanitária}

$\mathrm{Na}$ categoria "Análise dos aspectos conceituais e operacionais da VISA" foram analisadas 02 dissertações $(0,49 \%)$.

ALENCAR (2002), em sua dissertação de mestrado (anexo 1 02M09), sistematizou e discutiu aspectos conceituais e operacionais da vigilância e dos instrumentos de controle das doenças transmitidas por alimentos, com ênfase nas diferentes estratégias da vigilância. $O$ autor ressalta que o controle das doenças transmitidas por alimentos constitui um dos mais relevantes problemas de saúde pública na atualidade. Isto torna indispensável ao sistema de saúde a incorporação e ampla utilização de todos os instrumentos disponíveis para a vigilância e o controle destas doenças, pressupondo o desenvolvimento de programas de formação e capacitação de recursos humanos para atuação em pesquisa e em campo, o fortalecimento institucional (especialmente nas áreas de epidemiologia e laboratório de análise microbiológica de alimentos), além da atualização contínua da legislação pertinente.

MALAGUTI (2005), em sua dissertação de mestrado (anexo 1 05M37), discutiu as características, objetivos e vantagens da incorporação no Brasil de um modelo estratégico de vigilância de DTA segundo a experiência da rede nacional de caracterização molecular para a vigilância desses agravos em implantação em países industrializados, a PulseNet. O autor afirma que as doenças transmitidas por alimentos constituem um importante problema de saúde pública de países em desenvolvimento e industrializados; e conclui que, na sua multicausalidade, intrínseca aos modelos de desenvolvimento econômico, demanda abordagens multidisciplinares e ágeis no estabelecimento de estratégias para o seu 
controle e a aplicação experimental de modelos de vigilância, cujos resultados têm-se revelado satisfatórios

Ambas as pesquisas trataram diretamente sobre serviços de vigilância sanitária e as doenças transmitidas por alimentos, apontando a necessidade de regionalização dos serviços de vigilância sanitária, o conhecimento da realidade da área de atuação da Visa, bem como a constante capacitação de seus profissionais.

Para a Vigilância Sanitária poder cumprir com suas funções, mais especificamente em nível municipal, torna-se imprescindível que seus recursos humanos estejam capacitados, estruturados e adequados ao tipo de gestão municipal e ao universo de atuação local (SIMÕES, 2005), além do domínio da legislação vigente (SOTO et al., 2006). De acordo com FREO e REOLON (2006), a Organização Panamericana de Saúde considera que poucas regiões dispõem de um sistema adequado de Vigilância Sanitária de alimentos e que ainda são escassos os levantamentos nessa área. 


\subsubsection{OUTRAS CATEGORIAS}

Em "outras categorias" foram agrupadas àquelas em que tiveram apenas 01 tese ou dissertação em seu grupo.

\subsubsection{Comparação entre os efeitos dos cultivos orgânico e convencional}

BORGUINI (2006), em sua tese de doutorado (anexo 1 - 06D03), comparou os efeitos dos cultivos orgânico e convencional sobre as características físico-químicas, o teor de compostos antioxidantes, a atividade antioxidante e os resíduos de pesticidas de tomates cultivar Carmem. Considerando-se que o preparo doméstico de alimentos exerce efeitos expressivos sobre o nível de nutrientes em relação ao alimento in natura, particularmente no que tange ao teor de compostos antioxidantes e, conseqüentemente, na atividade antioxidante destes compostos, o autor verificou também a influência de diversas formas de preparo doméstico para o consumo de tomates. A autora observou que o tomate orgânico inteiro e o molho apresentaram teores médios de ácido ascórbico maiores que seus similares convencionais. O tomate orgânico apresentou teor médio de fenólicos maior que o tomate convencional, para todos os produtos e preparações. Não foi possível identificar diferença entre orgânicos e convencionais quanto ao teor de licopeno, para todas as preparações e produtos avaliados. Para as demais preparações e produtos, o tomate orgânico apresentou percentual maior de atividade antioxidante que o convencional. No caso do extrato aquoso, apenas o tomate inteiro e o molho orgânico e convencional não apresentaram diferenças, para os demais 
modos de preparo (sem pele, sem semente e purê) o tomate orgânico apresentou percentual médio de atividade antioxidante maior que o tomate convencional. Para o extrato etéreo pelo sistema beta-caroteno/ácido linoléico, quando comparou cultivo orgânico e convencional, observou que a atividade antioxidante do molho convencional foi maior que do molho orgânico. No entanto, para os tomates sem pele e sem semente, o orgânico apresentou valores médios significativamente maiores que aqueles obtidos para o tomate convencional. Para o extrato alcoólico pelo sistema betacaroteno/ácido linoléico, não encontraram diferenças quando se compararam as preparações e os produtos provenientes do cultivo orgânico e convencional. No caso do extrato aquoso, o tomate orgânico apresentou maior média de atividade antioxidante para todos os modos de preparo, exceto para o molho. A forma de cultivo foi um fator determinante em relação à presença de resíduos de pesticidas (permetrina, tebuconazol e ditiocarbamatos), uma vez que o tomate orgânico preparado de diversas formas não apresentou tais resíduos. A autora concluiu que, devido ao limitado tamanho da amostra, nenhuma generalização pôde ser estabelecida em relação ao tipo de cultivo e o valor nutricional dos tomates. No entanto, a partir dos resultados dos lotes de tomate avaliados, para a maioria dos parâmetros adotados, puderam observar níveis de superioridade para o tomate orgânico em relação ao convencional.

\subsubsection{Caracterização do perfil de profissionais que treinam manipuladores}

Tendo em vista a caracterização dos profissionais que treinam manipuladores de alimentos e a identificação das dificuldades das organizações para desenvolver esta atividade, GERMANO (2002), em sua dissertação de mestrado (anexo 1 - 02D33) realizou um levantamento a fim 
de caracterizar o perfil desses profissionais. Os resultados obtidos indicaram que a maioria dos treinadores são mulheres, em torno de 30 anos de idade, com formação em Nutrição que, apesar do caráter multiprofissional da ocupação, apenas pequena parcela possuía formação específica para atuar como educador. As dificuldades encontradas deviam-se à resistência dos treinados em aceitarem ordens de pessoas mais jovens e com menor experiência em cozinhas, à baixa escolaridade dos manipuladores, a pouca disponibilidade de tempo destes para participarem de treinamentos e à escassez de recursos financeiros das organizações. As situações consideradas mais importantes para treinar foram na admissão, as reciclagens e quando da ocorrência de não conformidade. O conteúdo mais freqüente era higiene pessoal e as metodologias mais empregadas aulas expositivas com auxílio de recursos impressos ou audiovisuais e demonstrações. A autora concluiu que as atividades de acompanhamento e avaliação não estavam sistematizadas. $O$ treinamento de manipuladores foi considerado importante para garantir a qualidade dos alimentos, assim como a segurança alimentar dos consumidores. Todavia a atividade, ainda, não constitui uma ação promotora da saúde, apesar de haver indícios de uma consciência nesta direção. GERMANO (2002) (anexo 1 - 02D33) recomenda ações no âmbito dos órgãos públicos, privados e dos responsáveis pelo treinamento que conduzam as intervenções de promoção da saúde.

\subsubsection{Detecção de autenticidade ou adulteração de alimentos}

A geléia real é um produto apícola que é muito utilizado como complemento alimentar por apresentar propriedades revitalizantes. Por conta da ausência de legislação e de padrões de identidade e qualidade, GARCIAAMOEDO (1999), em sua dissertação de mestrado (anexo 1 - 99M09), estabeleceu análises físico-químicas e químicas que possam ser usadas 
para caracterização e detecção de autenticidade ou adulteração da geléia real, enfatizando-se a determinação do ácido 10-hidroxi-trans-2-decenóico (10-HDA). Considerando-se os resultados obtidos durante o estudo, o autor preconizou as determinações de umidade, cinzas, lipídeos, proteínas, carboidratos, 10-HDA e o teste de solubilidade como principais itens a serem observados nesse tipo de investigação.

\subsubsection{Avaliação da biodisponibilidade de nutriente sintético e natural}

ZANUTTO (2000), em sua dissertação de mestrado (anexo 1 00M07), comparou a biodisponibilidade do 'beta'-caroteno sintético e de fonte natural, e verificou os efeitos da pectina cítrica na biodisponibilidade do 'beta'-caroteno, em 2 experimentos diferentes. A autora concluiu que a pectina cítrica interferiu na absorção do 'beta'-caroteno e que o 'beta'caroteno de fonte natural, foi melhor absorvido pelos organismos analisados.

\subsubsection{Desenvolvimento de metodologia para determinação de ácidos graxos trans}

BADOLATO (2000), em sua dissertação de mestrado (00M10), se propôs a desenvolver uma metodologia simples e eficiente para identificar e quantificar os ácidos graxos trans. A autora analisou 14 amostras de margarinas e cremes vegetais e 19 de gorduras vegetais hidrogenadas comercializadas no Brasil e 16 amostras de margarinas comercializadas no exterior. Todas as amostras foram transesterificadas e analisadas por 
cromatografia em fase gasosa, utilizando-se duas colunas capilares: sp 2560 de $100 \mathrm{~m}$ (Supelco) e cp Sil 88 de $50 \mathrm{~m}$ (Chronpack). A autora encontrou os seguintes teores de ácidos graxos trans totais: de 11,89 a 49,51\% nas gorduras hidrogenadas; de 0 a 20,55\% nas margarinas brasileiras e de 0 a $9,48 \%$ nas margarinas importadas. A autora concluiu que as duas colunas capilares: sp 2560 e cp sil 88, apresentaram aspectos positivos e negativos na separação dos ésteres metílicos dos ácidos graxos trans e conseqüentemente na identificação e quantificação dos mesmos. 


\subsection{A relação entre a Universidade e a Vigilância Sanitária}

As conseqüências diretas e indiretas da globalização, tais como, uma maior circulação e interação de pessoas, animais, produtos, e serviços e a rápida disseminação de patógenos, além da precarização das condições de vida e de trabalho reafirmam a necessidade de um Estado forte e capaz de interferir nas relações econômicas e sociais com o objetivo de preservar a vida e o ambiente, os interesses da coletividade e das comunidades (GARIBOTTI et al., 2006).

O aumento no número de teses e dissertações sinaliza o reconhecimento da Universidade de São Paulo na área científica e tecnológica. A demanda por pesquisas científicas não vem somente da Vigilância Sanitária, mas pelo próprio setor produtivo. Há empresas, motivadas pelas exigências de mercado, pelas maiores exigências para comercialização interna e exportação de seus produtos, que patrocinam pesquisas para que sejam avaliadas as tecnologias de produção.

Além da demanda do setor produtivo, outro fator que merece destaque é a demanda dos próprios órgãos de ciência e tecnologia, tais como o Conselho Nacional de Desenvolvimento Científico e Tecnológico CNPq, a Coordenação de Aperfeiçoamento de Pessoal de Nível Superior CAPES, que incentivam e financiam a pesquisa científica e o desenvolvimento tecnológico.

Embora grande parte das teses e dissertações analisadas nesse estudo, não tenha sido desenvolvida por demanda direta da própria Vigilância Sanitária de Alimentos, mas todas elas têm aplicabilidade na área, servindo de subsídio para esse serviço. Pois a Vigilância Sanitária precisa ter uma visão mais abrangente do que acontece, analisando os possíveis 
fatores que podem gerar riscos à população, visto que a maioria dos trabalhadores desse serviço não tem formação na área.

GARIBOTTI et al. (2006), afirmam que a maioria dos trabalhadores não teve formação específica sequer para atuar na área da saúde e, muito menos, na vigilância sanitária. Nem mesmo o pessoal de nível superior teve contato com conteúdos específicos da área durante o ensino de graduação. Pois, a maioria dos cursos da área da saúde e afins não abrange a temática da vigilância sanitária em seus programas. Geralmente, o ofício é aprendido na prática, na vivência dentro do serviço e por meio de iniciativa pessoal, pelo estudo da legislação sanitária, realização de cursos específicos, etc.

Devido à globalização e, através dela, a possível geração de novos riscos à população, houve uma maior valorização das ações de vigilância sanitária no país, tornando-se imprescindível a qualificação dos serviços para o cumprimento integral de suas atribuições e as pesquisas científicas podem ser uma chave-mestra para suprir essa necessidade.

Portanto, a ação da vigilância sanitária deve ser sempre balizada pela regra (lei, portaria, resolução, ou outra hierarquia legislativa) e esta deve ser fruto do conhecimento. $\mathrm{O}$ conhecimento que suporta a regra sanitária deve ser produzido a partir de um espaço cooperativo entre a vigilância sanitária e a sociedade, cooperação ainda a ser construída. Nos órgãos de vigilância sanitária não é possível encontrar todo o conhecimento necessário no enfrentamento de realidades cada vez mais complexas e de riscos sanitários oriundos de novas tecnologias introduzidas nos processos produtivos de bens e serviços, por exemplo. A articulação de produção de saberes na área entre universidades, institutos de pesquisas, setor regulado, nas organizações da sociedade é o desafio para uma atuação mais presente e consistente desta política de proteção (NETO et al., 2006) 
Importante ressaltar que um novo conhecimento deve ser sempre validado, considerando os múltiplos interesses que podem ser mobilizados pela ação da vigilância sanitária (NETO et al., 2006).

A construção do conhecimento que apóia as ações de vigilância sanitária é bastante complexa. Portanto, segundo NETO et al. (2006) é fundamental que essa construção tenha certas características:

1. Cooperação: buscar o conhecimento aprioristicamente, onde ele estiver. Nas universidades, nos institutos de pesquisa, no setor regulado, nas organizações não-governamentais.

2. Comunicação: o conhecimento produzido em órgãos de pesquisa e formação de interesse da vigilância sanitária deve ser comunicado, transformado em informação, tanto à sociedade como aos órgãos de vigilância sanitária.

3. Incorporação: o conhecimento produzido e problematizado nas diferentes realidades sociais, econômicas e políticas deve ser incorporado e utilizado mediante critérios rigorosos de avaliação, considerando as implicações e repercussões no campo da bioética e da ética em pesquisa.

A universidade é um espaço para a produção de conhecimento, mas que não se trata de qualquer conhecimento. Trata-se da produção de conhecimento significativo que precisa dar conta do avanço da fronteira da ciência da tecnologia, da cultura e também dos problemas atuais que atingem a comunidade, pois é reconhecida, também pelos seus serviços prestados à sociedade (BEHRENS, 1998; TRIGUEIRO, 2001).

Acerta a ANVISA quando investe na Universidade pública com parceira na produção de conhecimentos e de capacitação em vigilância sanitária e acerta a Universidade de São Paulo quando acolhe a idéia que propõe a integração entre os espaços de ensino e pesquisa e o de trabalho, a transferência tecnológica para a melhoria da atuação profissional e a reflexão da área na perspectiva da interdisciplinaridade, buscando manter a 
independência e crítica necessária ao espaço da discussão criativa. Nesta perspectiva, ganha a vigilância sanitária no fortalecimento de sua inserção na saúde coletiva como campo fundamental para a promoção e proteção da saúde e qualidade de vida (CECOVISA, 2005).

Pois, não existirá um Sistema Nacional de Vigilância Sanitária efetivo se não existir uma Política de Recursos Humanos que o sustente e, em contra partida, não existirá Política de Recursos Humanos sem clara definição da Política de Vigilância Sanitária (SOUZA et al., 2005).

A criação de uma agência regulatória específica, a ANVISA, para a área de medicamentos, alimentos e ambiente, expressa a determinação do Estado de fortalecer sua capacidade de intervenção nessas áreas, e resulta necessariamente em demandas por novos conhecimentos científicos (BARRETO, 2004).

Para estreitar os laços entre os serviços de Vigilância Sanitária e CECOVISAs, aprovou-se a Portaria 702, de 10 de junho de 2008, que aprova e promulga a Regulamentação dos Centros Colaboradores em Vigilância Sanitária - Cecovisas. Essa Portaria aborda as regras para que as universidades interessadas em aderir à rede saibam como estabelecer esta parceria com a ANVISA.

Atualmente, novas parcerias entre universidades públicas e a ANVISA estão sendo firmadas para a formação de novos CECOVISAs, entre elas estão a Universidade Federal do Acre (UFCA), a Universidade Estadual de Goiás (UEG) e a Escola de Saúde Pública do Ceará (UFC), juntamente com as vigilâncias sanitárias destas localidades (ANVISA, 2008).

A pesquisa científica desempenha papel fundamental, na pósgraduação, também por tornar acessível aos estudantes os contínuos avanços do saber. Como "decodificadores" do conhecimento novo, os 
pesquisadores podem conhecer criticamente o detalhe para integrá-lo ao conhecimento já estabelecido na área ou em outras áreas do conhecimento, para atingir uma dimensão sistêmica (TRINDADE e PRIGENZI, 2002).

Tal comunicação vai implicar na disponibilização de uma informação técnica para uso leigo que permita a este consumidor funcionar como agente controlador do seu consumo, atuando assim, sem abdicar da sua condição de consumidor, como linha auxiliar do Estado, incorporando em seu comportamento parte das atribuições controladoras do Estado (LEFÈVRE, 2005).

As atividades que compõem os projetos do CECOVISA são resultantes de demandas que emergem da reflexão e da necessidade cotidiana dos serviços de vigilância sanitária componentes do sistema nacional, e que desta forma alimentam o espaço da pesquisa e do ensino, além das provocações teóricas advindas do campo interdisciplinar no qual a vigilância sanitária está inserida (CECOVISA, 2005).

A produção do conhecimento científico destaca-se por não ser definida apenas pelo imediatismo das necessidades de elaboração de políticas. O sistema científico é relativamente independente dessas necessidades mais imediatas e seu objetivo primário é produzir o conhecimento e fazê-lo circular e difundir-se em redes (BARRETO, 2004).

A Vigilância Sanitária é um campo de práticas construído por diversas áreas de conhecimento, que enfrenta o desafio da articulação e há que se encontrar estratégias junto aos segmentos menos privilegiados da população para fazer cumprir o tão discutido princípio da equidade. Questão que reflexiona a capacidade do serviço de vigilância sanitária de atuar em defesa da vida e não em resposta às demandas dos interesses econômicos (GARIBOTTI et al., 2006). 
Com base nesses aspectos, encontra-se em tramitação um acordo que prevê a criação Cátedra ANVISA/USP de Vigilância Sanitária, para promover, considerando a influência da USP, a institucionalização acadêmica e científica do campo da Vigilância Sanitária no Brasil. Com isso, espera-se potencializar a implementação do campo de conhecimento em Vigilância Sanitária na USP, desenvolvendo mais e melhores estudos e pesquisas em Vigilância Sanitária, introduzindo mais amplamente o tema nos programas de graduação e de pós-graduação e contribuindo decisivamente para o aperfeiçoamento institucional do sistema e da política pública de Vigilância Sanitária, no Brasil e no mundo. Com a implementação da Cátedra ANVISA/USP de Vigilância Sanitária, a USP estará em melhores condições para trabalhar com a Vigilância Sanitária, que se afirma como um ingrediente chave das estratégias de competição entre agentes econômicos*.

* Comunicação pessoal de Assessoria de Comunicação Institucional FSP/USP, em 14 de novembro de 2007, recebida por correio eletrônico 


\section{CONSIDERAÇÕES FINAIS}

Pôde-se observar dentre as 337 teses e dissertações analisadas nesse estudo, que houve um aumento no número de pesquisas pertinentes à área de Vigilância Sanitária de Alimentos a partir do ano 2000. Fato este que pode ser relacionado à criação da ANVISA através da Lei 9.782, de 26 de janeiro de 1999, e também aos avanços científicos e tecnológicos experimentados na última década.

Observa-se, também, que as pesquisas mais antigas ficaram limitadas às análises de microrganismos em alimentos, através de métodos microbiológicos convencionais, e análises bromatológicas, ou seja, o foco de pesquisa era somente o produto final; enquanto as pesquisas mais recentes ampliaram os temas de seus estudos, versando sobre alimentos transgênicos, implantação do sistema APPCC, análise de alimentos minimamente processados, entre outros, e fazendo uso de tecnologia de ponta, como a inserção dos métodos moleculares na pesquisa de microrganismos, o que comprova o avanço científico e tecnológico vivenciados no momento presente. Há uma preocupação não só com a qualidade do produto final, mas sim, com a qualidade de todo o processo de produção. Visto que a Vigilância Sanitária não é só a inspeção sanitária em si, mas tem início na avaliação de riscos e na análise do processo.

Um fator importante observado foi que, praticamente, todas as pesquisas envolveram uma análise da atual situação foco de estudo para poder apresentar uma possível intervenção. Afinal, tão importante quanto identificar problemas é divulgar informações com um grau de segurança mais elevado para propor algum tipo de alteração na área. 
A contribuição das pesquisas científicas à Vigilância Sanitária de Alimentos tem sido de extrema valia, visto que as mesmas estão cada vez mais adequadas à realidade da população, identificando as principais ocorrências consideradas de agravo à saúde, através da análise e desenvolvimento de novos métodos de processamento de alimentos minimizando riscos aos consumidores, incorporação de tecnologia de ponta na identificação de surtos alimentares e implantação de controles de qualidade que garantam a inocuidade do alimento.

O acesso desigual ao conhecimento científico e o controle desigual sobre sua produção ou distribuição são temas importantes (TILLY, 2006). Por isso, reforça-se ainda mais a necessidade de uma divulgação dos resultados das pesquisas, por diversos meios, seja através do ensino, da aplicação nas atividades profissionais, como também, o que é mais importante, pela divulgação nos meios de comunicação de massa, como jornais, revistas livros, folhetos, rádio, televisão, entre tantos outros. Pois a junção da educação com a comunicação torna-se uma forma de mediação bastante eficaz nos processos de proteção aos riscos sanitários (JANES, 2007).

Considera-se que são cada vez mais necessários conhecimentos científicos que fundamentem os processos de fiscalização na área de alimentos, trazendo maiores benefícios à saúde da população, com menos custos econômicos ou sociais ao nosso país. A implantação de técnicas mais rápidas e eficazes na deteç̧ão de microrganismos, que representem risco imediato de doenças transmitidas por alimentos, é fundamental para a produção de novos conhecimentos técnicos que viabilizem uma ação sanitária mais eficiente.

A Universidade deve realizar pesquisas de alto nível, que favoreça não apenas o pesquisador ou a própria Universidade, mas que possa fornecer notável contribuição para a solução dos problemas da sociedade. 
Portanto, a pesquisa é indispensável, pois, se a Universidade não o fizer; ninguém mais tem condições nem preparo para substituí-la nesse papel; sendo um desafio ao qual ela não pode furtar-se, sob pena de perder muito da justificativa de sua existência (SCHMITZ, 1995).

As pesquisas científicas surgem em função das necessidades do campo de Vigilância Sanitária, mas esta demanda muito mais do que já foi feito e, até mesmo, do que está sendo feito no momento. Recomenda-se a continuidade de novas pesquisas, a fim de abrir novos campos de estudo na área de prática de saúde pública; pois, apesar de toda a evolução científica e tecnológica, ainda há muito a ser trabalhado e alcançado.

Através da sistematização realizada no presente estudo, observou-se que embora com diferentes objetivos ou enfoques, todas as dissertações e teses analisadas apresentaram algum grau de contribuição para o conhecimento de temas relacionados à área de alimentos, apresentando direta ou indiretamente potencial de aplicação na área de Vigilância Sanitária de Alimentos. Esse conhecimento científico e tecnológico está disponível para os profissionais que atuam em Vigilância Sanitária, podendo contribuir para o aprimoramento dessa prática.

Observa-se, nos últimos anos, que a Universidade de São Paulo tem ampliado a sua participação em pesquisas relacionadas a temas pertinentes à Vigilância Sanitária, bem como na capacitação de recursos humanos na área. Essa integração vêm se consolidando de forma cada vez mais importante. Entende-se ser necessário não somente a manutenção dessas ações, mas, também, com base nas análises dos dados apresentados neste estudo, buscar mecanismos para o aprimoramento desta relação de forma a melhorar em efetividade e eficácia as ações que objetivam a promoção e a proteção da saúde humana. Visto que é reconhecida a importância da integração entre Universidade e Vigilância Sanitária de Alimentos no fornecimento subsídios que permitam capacitar e munir os profissionais da 
área de inspeção, norteando práticas coerentes através de informações que venham servir de base e orientação para a evolução das ações de Vigilância Sanitária. 


\section{REFERÊNCIAS ${ }^{1}$}

Adam M, Matarjemy Y. Perigos associados a diferentes alimentos e seu controle. In: Segurança básica dos alimentos para profissionais de saúde. Organização Mundial de Saúde. São Paulo: Roca, 2002.

Addôr ECL. Determinação dos pontos críticos no processo de importação de produtos termolábeis [dissertação de mestrado]. São Paulo: Faculdade de Saúde Pública da USP; 2004.

Akutsu RC, Botelho RA, Camargo EB, Sávio KEO, Araújo WC. Adequação das boas práticas de fabricação em serviços de alimentação. Rev Nutr Campinas. 2006;18:419-427.

Alencar LCM. Vigilância e controle das doenças transmitidas por alimentos [dissertação de mestrado]. São Paulo: Faculdade de Saúde Pública; 2002.

Alferez - Consultoria e Assessoria Radiológica. Nós e as Radiações. [homepage da internet]. Belo Horizonte, 2008 [acesso em 26 agosto 2008]. Disponível

em:

http://www.cultura.com.br/radiologia/diversos/esterilizacao.htm

Almeida MLP. Como elaborar monografias. 4 ed. Belém: CEJUP, 1996.

Almeida MCS. Avaliação dos teores de arsênio total em cação, por meio de técnicas espectrométricas [dissertação de mestrado]. São Paulo: Faculdade de Ciências Farmacêuticas; 2005.

\footnotetext{
${ }^{1}$ Apresentadas Segundo o Guia de Apresentação de Teses $2^{\mathrm{a}}$. ed - Biblioteca/CIR. São Paulo: FSP/USP; 2006.
} 
Almeida MTT. Avaliação microbiológica de alfaces (Lactuva sativa) em restaurantes self-service no Município de Limeira - SP [dissertação de mestrado]. São Paulo: Escola Superior de Agricultura "Luiz de Queiroz"; 2006.

Andrade SRR. Processamento mínimo de mamão (Carica papaya L.): efeitos de aditivos e atmosfera modificada na qualidade do produto [dissertação de mestrado]. São Paulo: Escola Superior de Agricultura "Luiz de Queiroz"; 2006.

Andrigheto C. Disseminação de Salmonella enteriditis isoladas em uma cadeia produtiva industrial avícola: determinação do perfil de resistência a antimicrobianos e caracterização genotípica [tese de doutorado]. São Paulo: Faculdade de Ciências Farmacêuticas; 2006.

ANVISA - Agência Nacional de Vigilância Sanitária. Apresentação. [homepage na internet]. Brasília, 2003 [acesso em 25 outubro 2006]. Disponível em: http://www.anvisa.gov.br/institucional/anvisa/apresentacao.htm

ANVISA - Agência Nacional de Vigilância Sanitária. Resíduos de agrotóxicos em alimentos. Rev Saúde Pública. 2006; 40: 361 - 363.

ANVISA - Agência Nacional de Vigilância Sanitária. Apresentação. [homepage na internet]. Brasília, 2008 [acesso em 12 julho 2008]. Disponível em: http://www.anvisa.gov.br/ divulga/noticias/2008/080708.htm

Arias-Echandi ML, Antillón F. Contaminación microbiológica de los alimentos en Costa Rica. Rev Biomed. Costa Rica. 2000; 11: 113-122.

Assis OBG, Forato LA, Britto D. Revestimentos comestíveis protetores em frutos minimamente processados. Hig Alim. 2008; 22: 99 - 108. 
Badaró ACL, Azeredo RMC, Almeida MEF. Vigilância sanitária de alimentos: uma revisão. Rev Dig Nutrição. 2007; 01.

Badini KB, Nader Filho A, Amaral LA, Germano PML. Risco à saúde representado pelo consumo de leite cru comercializado clandestinamente. Rev. Saúde Pública. 1996; 30: 549 - 552.

Badolato ESG. Aspectos analíticos da determinação de ácidos graxos trans em margarinas e gorduras vegetais hidrogenadas [dissertação de mestrado]. São Paulo: Faculdade de Ciências Farmacêuticas; 2000.

Balioni GA, Fernandes FV, Soares MMSR, Ribeiro MC. Avaliação higiênicosanitária de alfaces agro-ecológicas e cultivadas com agrotóxico, comercializadas na região de Campinas. Hig Alim. 2003; 17: 73 - 77.

Banco Mundial - Unidade de Gerenciamento do Brasil. Enfrentando o desafio das doenças não transmissíveis no Brasil [homepage da internet]. Brasília , 2005. [acesso em 09 de abril de 2008]. Disponível em: http://www.cev.org.br/biblioteca/RelatorioBancoMundialBR.pdf

Baracat RS. Avaliação do processo por embalagem tipo atmosfera modificada na conservação da carne bovina porcionada [tese de doutorado]. São Paulo: Escola Superior de Agricultura "Luiz de Queiroz"; 2006.

Barrera SMA. Análise qualitativa e quantitativa da rotulagem de produtos à base de creatina para praticantes de atividades físicas [dissertação de mestrado]. São Paulo: Instituto de Química; 2004.

Barreto ML. O conhecimento científico e tecnológico como evidência para políticas e atividades regulatórias em saúde. Ciência \& Saúde Coletiva. 2004; 9: 329 - 338 . 
Bastos AA. O processo de trabalho em vigilância sanitária de medicamentos, na sua etapa de comercialização [dissertação de mestrado]. Bahia: Universidade Federal da Bahia, 2006.

Behrens MA. A prática pedagógica dos professores universitários: perspectivas e desafios. Educação. 1998; 21: 81 - 91.

Bellarde FB, Silva DC, Catanozi MPM. Avaliação das condições higiênicosanitárias de "gelinho" produzido artesanalmente e comercializado na cidade de Araraquara-SP. REVISA. 2005;1:58-64.

Beloti V. Fatores que podem influenciar o desempenho de métodos rápidos para enumeração de microrganismos indicadores de higiene em leite pasteurizado [tese de doutorado]. São Paulo: Faculdade de Ciências Farmacêuticas; 2000.

Bianchini R. Carotenóides dos pimentões amarelos (capsicum annuum, l). Caracterização e verificação de mudanças com o cozimento [dissertação de mestrado]. São Paulo: Faculdade de Ciências Farmacêuticas; 1994.

Blumer L. Efeito da radiação gama e do tratamento térmico na conservação do suco natural de maçã (malus domestica), cv. Gala [dissertação de mestrado]. São Paulo: Centro de Energia Nuclear e Agricultura; 1995.

Bodstein RCA. Complexidade da ordem social contemporânea e redefinição da responsabilidade pública. In: Rozenfeld S. Fundamentos da vigilância sanitária. Rio de Janeiro: Fiocruz, 2000.

Borguini RG. Avaliação do potencial antioxidante e de algumas características físico-químicas do tomate (Lycopersicon esculentum) orgânico em comparação ao convencional [tese de doutorado]. São Paulo: Faculdade de Saúde Pública; 2006. 
Brasil. Constituição da República Federativa do Brasil. Diário Oficial da União, Brasília. 1988.

Brasil. Lei Federal n8078 de 11 de setembro de 1990. Dispõe sobre a proteção do consumidor e dá outras providências. Diário Oficial da União. Brasília, 1990a.

Brasil. Lei Federal n8080 de 19 de setembro de 1990. Dispõe sobre as condições para a promoção, proteção e recuperação da saúde e dá outras providências. Diário Oficial da União. Brasília, 1990b.

Brasil. Ministério da Saúde. Portaria n01428 de 26 de novembro de 1993. Aprova o regulamento técnico para inspeção sanitária de alimento; diretrizes para o estabelecimento de Boas Práticas de Produção e de Prestação de Serviços na Área de Alimentos; e regulamento técnico para o estabelecimento de padrão de identidade e qualidade para serviços e produtos na área de alimentos. Brasília, 1993.

Brasil. Ministério da Saúde. Secretaria de Vigilância Sanitária. Portaria n³26 de 30 de julho de 1997. Regulamento Técnico sobre as Condições Higiênico-Sanitárias e de Boas Práticas de Fabricação para Indústrias de Alimentos. Brasília, 1997.

Brasil. Ministério da Agricultura, Departamento de Defesa e Inspeção Vegetal. Lei $n^{\circ} 7802$, de 11 de julho de 1989. Legislação Federal de Agrotóxicos e Afins. Brasília, 1998a.

Brasil. Ministério da Agricultura, Departamento de Defesa e Inspeção Vegetal. Portaria 03, de 16 de janeiro de 1992. Legislação Federal de Agrotóxicos e Afins. Brasília, 1998b. 
Brasil. Lei Federal no9782 de 26 de janeiro de 1999. Cria a Agência Nacional de Vigilância Sanitária, define o Sistema Nacional de Vigilância Sanitária e dá outras providências. Brasília, 1999.

Brasil. Ministério da Saúde. A Agência Nacional de Vigilância Sanitária. Resolução - RDC $\mathrm{n}^{0} 12$, de 02 de Janeiro de 2001. Dispõe sobre 0 regulamento técnico sobre padrões microbiológicos para alimentos. Diário Oficial da União. Brasília, 2001.

Brasil. Ministério da Saúde. Agência Nacional de Vigilância Sanitária. Resolução - RDC n²1, de 26 de Janeiro de 2001. Dispõe para 0 regulamento técnico para irradiação de alimentos. [homepage da internet] Diário Oficial da União, Brasília. [acesso em 12 junho 2008] Disponível em: http://www.anvisa.gov.br/index ato.htm

Bocalon EC. A transferência de metais para os alimentos e sua possível relação com a saúde do consumidor [dissertação de mestrado]. São Paulo: Escola de Engenharia de São Carlos; 2005.

Borguini RG. Tomate (Lycopersicum esculentum Mill) orgânico: o conteúdo nutricional e a opinião do consumidor [dissertação de mestrado]. São Paulo: Escola Superior de Agricultura "Luiz de Queiroz"; 2003.

Borrell JG. Análise da microbiota do leite materno "in natura" após armazenamento e aquecimento [tese de doutorado]. São Paulo: Faculdade de Medicina; 2004.

Bueno E. À sua saúde: a vigilância sanitária na história do Brasil. Brasília: Ministério da Saúde: Agência Nacional de Vigilância Sanitária, 2005. 
Campos MRH, Marques FPP, Paschoal DNR, Patrício CCF, Araújo LR. Qualidade microbiológica de poços artesianos presentes em unidades de alimentação e nutrição da cidade de Goiânia (GO): análise de laudos laboratoriais constantes na divisão de saneamento da vigilância sanitária municipal. Hig Alim. 2006; 21: 362 - 363.

Campregher RB. Utilização de metodologias convencional e "Simplate" para avaliação das condições microbiológicas de suco de laranja pasteurizado e não pasteurizado [dissertação de mestrado]. São Paulo: Escola Superior de Agricultura "Luiz de Queiroz"; 2000.

Cardoso RCV, Pimentel SS, Santana CS, Moreira LN, Cerqueira SC. Comida de rua: estrutura, regulação e higiene em pontos de venda da cidade de Salvador, BA. Hig Alim. 2006;20:37-43.

Carvalho LT, Carvalho ALT. Utilização de ferramentas da qualidade em indústria de alimento. Hig Alim. 2006;20:20-27.

CECOVISA - Centro Colaborador em Vigilância Sanitária. Vigilância Sanitária: textos e contextos. São Paulo: CECOVISA, 2005.

CECOVISA - Centro Colaborador em Vigilância Sanitária. [homepage na internet]. São Paulo [acesso em 11 dezembro 2007]. Disponível em: http://www.fsp.usp.br/cecovisa

Cella AL. Ocorrência de agrotóxicos organofosforados e organoclorados dicofol em maçãs (Malus domestica) [dissertação de mestrado]. São Paulo: Centro de Energia Nuclear na Agricultura; 2002. 
Cestari Junior A. Avaliação do potencial de aplicação do processo de irradiação para a redução de Salmonella spp. em diferentes variedades de mangas (Mangifera indica L.) minimamente processadas e avaliação da vida de prateleira [dissertação de mestrado]. São Paulo: Faculdade de Ciências Farmacêuticas; 2005.

Charanek KH. Determinação de alguns nutrientes e contaminantes e avaliação da distribuição de alguns elementos em amostras de soja transgênica e convencional, através do acoplamento HPLC-ICP [dissertação de mestrado]. São Paulo: Instituto de Química; 2006.

Chiara VL, Chiara SE. Artigos de revisão: contribuições com enfoque em Ciência da Nutrição. Rev Nutr Campinas. 2006; 19: 103 - 110.

Chicourel EL. Mercúrio em pescado - quantificação e o efeito do preparo para o consumo [dissertação de mestrado]. São Paulo: Faculdade de Ciências Farmacêuticas; 1993.

Cintra P. Parâmetros nutricionais e hematológicos de ratos alimentados com soja (Glycine Max L.) geneticamente modificada [dissertação de mestrado]. São Paulo: Faculdade de Ciências Farmacêuticas; 2005.

Colombari V. Surto de intoxicação alimentar por Staphylococcus aureus: caracterização fenotípica e genotípica de cepas de origem humana e de alimentos [dissertação de mestrado]. São Paulo: Faculdade de Ciências Farmacêuticas; 2002.

Costa EA. O trabalhador de vigilância na construção de uma nova vigilância sanitária: profissional de saúde ou fiscal? In: Seminários temáticos permanentes. Brasília: Agência Nacional de Vigilância Sanitária, 2001. 
Costa EA. Conhecimento e formação profissional em vigilância sanitária. REVISA. 2005;1:141-146.

Costa EA. Vigilância sanitária - proteção e defesa da saúde. São Paulo: SOBRAVIME, 2004.

Dallari SG, Bravo ES, Ribeiro IS. Vigilância sanitária de alimentos de consumo imediato no município de São Paulo - a importância da informação para o planejamento. Hig Alim. 2000;14: 24 - 35.

Dallari SG. O direito sanitário como campo fundamental para a vigilância sanitária. In: Marques MCC, Carvalho ML, Silveira D, de Castro PC, Ibañez N. Vigilância sanitária - teoria e prática. São Paulo: CEALAG, 2005.

De Deus MB, Holland N, Moraes CMM de, Stamford TLM. Microrganismos patogênicos e temperaturas de exposição de carne bovina servida em restaurantes self-service da cidade de Natal (RN), Brasil. REVISA. 2005;1:237-245.

De Seta MH, Pepe VLE, Oliveira GOD. Gestão e vigilância sanitária: modos atuais do pensar e fazer. Rio de Janeiro: FIOCRUZ, 2006.

Destro MT. Sistema HACCP e a segurança dos alimentos. Rev Nac da Carne. 1998;255.

Duailibi SR. Alimentos de rua em áreas hospitalares: aspectos sanitários e socioeconômicos [dissertação de mestrado]. São Paulo: Faculdade de Saúde Pública; 2004.

Duarte M. Determinação de nitratos e nitritos em leite e em misturas com soro [dissertação de mestrado]. São Paulo: Faculdade de Ciências Farmacêuticas; 1996. 
Façanha SHF, Ferreira NDL, Monte ALS. Avaliação da garantia da qualidade higiênico-sanitária do programa de alimentação escolar da cidade de sobral - CE. Hig Alim. 2002;16:54-58.

Fattori FFA, Souza LC, Braoios A, Ramos APD, Silva MA, Tashima NT, Neves TRM, Barbosa RL. Aspectos sanitários em trailers de lanche nos municípios de Presidente Prudente, SP. Hig Alim. 2005;19:

Feldsini P, Abeyta C, Andrews WH. AOAC International methods committee guidelines for validation of qualitative and quantitative food microbiological official methods of analysis. J AOAC Int 2002; 85(5):1187-2000.

Ferrari CKB. Oxidação lipídica em salsichas comercializadas nos sacolões municipais de São Paulo [dissertação de mestrado]. São Paulo: Faculdade de Saúde Pública; 1998.

Ferreira AB. Conhecendo melhor a rotulagem nutricional dos alimentos: uma análise crítica [dissertação de mestrado]. São Paulo: Faculdade de Ciências Farmacêuticas; 2004.

Franco BDGM. Critérios microbiológicos para avaliação da qualidade em alimentos. In: Franco BDGM, Landgraf M. Microbiologia de alimentos. São Paulo: Atheneu, 2002a.

Franco BDGM. Métodos de análise. In: Franco BDGM, Landgraf M. Microbiologia de alimentos. São Paulo: Atheneu, 2002b.

Franco MJM. Aplicação da metodologia APPCC - análise de perigos e pontos críticos de controle - como ferramenta para reuso de água na indústria: modelo para indústria de aromas e essências [dissertação de mestrado]. São Paulo: Escola Politécnica; 2007. 
Freitas EI, Lemos AA, Marin VA. Validação de métodos alternativos qualitativos na detecção de patógenos alimentares. Ciência \& Saúde Coletiva 2006 (4):1073-1083.

Freo JD, Reolon J. Qualidade dos produtos derivados da carne e do leite, industrializados pelas agroindústrias de Frederico Westphalen, RS. Hig Alim. 2006; 21: 35

Fung TT. Association between dietary patterns and plasma biomarkers of obesity and cardiovascular disease risk. Am J Clin Nutr 2001;73:61-67.

Garcia-Amoedo LH. Geléia Real: Análises físico-químicas e químicas úteis para a caracterização e detecção da autenticidade ou adulteração do produto [dissertação de mestrado]. São Paulo: Faculdade de Ciências Farmacêuticas; 1999.

Garibotti V, Hennington EA, Selli L. A contribuição dos trabalhadores na consolidação dos serviços municipais de vigilância sanitária. Cad Saúde Pública. 2006; 22: 1043 - 1051.

Germano MIS. Promoção da saúde: desafio para os profissionais envolvidos no treinamento de manipuladores de alimentos [tese de doutorado]. São Paulo: Faculdade de Saúde Pública; 2002.

Gigante DP, Barros FC, Post LAC, Olinto MTA. Prevalência de obesidade em adultos e seus fatores de risco. Rev Saúde Pública. 1997; 31: 236 - 246.

Giora CGB. Avaliação in vivo da qualidade protéica da soja geneticamente modificada [dissertação de mestrado]. São Paulo: Faculdade de Ciências Farmacêuticas; 2004. 
Gottardi CPT, Souza CAS de, Schmidt V. Surtos de toxinfecção alimentar no município de Porto Alegre / RS, no período de 1995 a 2002. Hig Alim. 2006;20:50-55.

Guerrante RDS. Transgênicos - uma visão estratégica. Interciência, 2003.

Hanashiro A. Avaliação da qualidade higiênico-sanitária e nutritiva de bentôs comercializados no bairro da Liberdade, São Paulo [dissertação de mestrado]. São Paulo: Faculdade de Saúde Pública; 2002.

IBGE - Instituto Brasileiro de Geografia e Estatística. Pesquisa de orçamentos familiares 2002 - 2003. Primeiros resultados - Brasil e grandes regiões. Rio de Janeiro; 2004.

IAEA - International Atomic Energy Agency. Facts about food irradiation. Vienna, 1991.

Instituto Adolfo Lutz. Normas analíticas do Instituto Adolfo Lutz, métodos químicos e físico-químicos para análise de alimentos. 3. ed. São Paulo: Instituto Adolfo Lutz, 1985.

Janes MW. A contribuição da comunicação para a saúde: estudo de comunicação de risco via rádio na Grande São Paulo [dissertação de mestrado]. São Paulo: Faculdade de Saúde Pública, 2007.

Jay JM. Microbiologia de alimentos. 6. ed. Porto Alegre: Artmed, 2005.

Jesus RS. Estabilidade de "Minced Fish" de peixes amazônicos durante o congelamento [tese de doutorado]. São Paulo: Faculdade de Ciências Farmacêuticas; 1999. 
Konradsen F, van der Hoek W, Cole DC, Hutchinson G, Daisley H, Singh S, Eddleston M. Reducing acute poisoning in developing countries - options for restricting the availability of pesticides. Toxicology. 2003; 192: $249-261$.

Lajolo FM, Nutti MR. Transgênicos - bases científicas da sua segurança. Sociedade Brasileira de Alimentação e Nutrição, 2003.

Landgraf M. Microrganismos indicadores. In: Franco BDGM, Landgraf M. Microbiologia de alimentos. São Paulo: Atheneu, 2002.

Landgraf M. Alterações químicas causadas por microrganismos. In: Franco BDGM, Landgraf M. Microbiologia de alimentos. São Paulo: Atheneu, 2002.

Lanzillotti HS, Pereira AL, Kornis GEM. Modelo conceitual simbólico do sistema de alimentação coletiva. Hig Alim. 2006;20: 20 - 28.

Lefèvre F. Vigilância Sanitária e comunicação empoderadora. In: CECOVISA - Centro Colaborador em Vigilância Sanitária. Vigilância Sanitária: textos e contextos. São Paulo: CECOVISA, 2005.

Lefèvre F, Marques MCC, Lefèvre AMC, Latorre MRD de O, Balbinot R, Medeiros IY de, Oliveira NGS, Seragi L. Representação social da vigilância sanitária pela população do município de Águas de Lindóia: análise da percepção de alguns riscos relevantes. REVISA. 2005;1:22-30.

Leite LHM, Waissmann W. Surtos de toxinfecções alimentares de origem domiciliar no Brasil de 2000 - 2002. Hig Alim. 2006; 20: 56 - 59.

Lemes VRR. Avaliação de resíduos de ditiocarbamatos e etileotiouréia (ETU) em fruta e sua implicação na saúde pública [dissertação de mestrado]. São Paulo: Faculdade de Saúde Pública; 2003. 
Lima JX, Oliveira LF. O crescimento do restaurante self-service: aspectos positivos e negativos para o consumidor. Hig Alim. 2005;19: 32 - 34.

Lima KSC, Lima ALS, Godoy RLO, Nascimento MGF. Efeito da radiação gama sobre a qualidade higiênico-sanitária de refeição pronta para o consumo. Hig Alim. 2008; 22: 67 - 72.

Lira EN. Ocorrência de doenças transmitidas por alimentos no período de 1999 a 2003, em Guarapuava-PR: um levantamento epidemiológico [dissertação de mestrado]. São Paulo: Escola de Enfermagem de Ribeirão Preto; 2005.

Lisita MO. Evolução da população bacteriana na linha de produção do queijo minas frescal em uma indústria de laticínios [dissertação de mestrado]. São Paulo: Escola Superior de Agricultura "Luiz de Queiroz"; 2005.

Lopes EA. Análise de perigos e pontos críticos de controle (APPC/HACCP) na produção de farinha de trigo: estudo microbiológico da etapa de molhagem do trigo [dissertação de mestrado]. São Paulo: Faculdade de Ciências Farmacêuticas; 2002.

Lucca A. Cachorro-quente comercializado em locais públicos: pontos críticos e características do mercado [dissertação de mestrado]. São Paulo: Faculdade de Saúde Pública; 2000.

Lucca A, Torres EA. Condições de higiene de "cachorro-quente" comercializado em vias públicas. Rev Saúde Pública. 2002;36:350-352.

Lucchese G. Vigilância sanitária e regulação do risco. In: Lucchese G. Globalização e regulação sanitária: os rumos da vigilância no Brasil. São Paulo: Fundação Osvaldo Cruz, 2001. 
Lucchese G. Globalização e vigilância sanitária. Os rumos da vigilância sanitária no Brasil [tese de doutorado]. Rio de Janeiro: Escola Nacional de Saúde Pública / Fundação Oswaldo Cruz; 2001.

Lucchese G. A vigilância sanitária no sistema único de saúde. In: De Seta MH, Pepe VLE, Oliveira GOD. Gestão e vigilância sanitária: modos atuais do pensar e fazer. Rio de Janeiro: FIOCRUZ, 2006. p. 33-48.

Luengo RFA. Dimensionamento de embalagens para comercialização de hortaliças e frutas no Brasil [tese de doutorado]. São Paulo: Escola Superior de Agricultura "Luiz de Queiroz"; 2005.

Machado MM, Oliveira AL, Bueno PHS, Pinto FC, Correia RF. Efeito da radiação gama e do tipo de embalagem sobre a estabilidade de lombo suíno armazenado sob refrigeração - avaliação físico-química e microbiológica. Him Alim. 2006; 21: 84.

Maciel E. Desenvolvimento e validação de metodologia analítica de multiresíduos para quantificação de resíduos pesticidas em manga (Mangifera indica) [dissertação de mestrado]. São Paulo: Interunidades em Ecologia de Agroecossistesmas; 2005.

Malaguti R. Novas abordagens da vigilância de doenças transmitidas por alimentos [dissertação de mestrado]. São Paulo: Faculdade de Saúde Pública; 2005.

Marchioni DML, Zacarelli EM. Avaliação da temperatura em refeições transportadas de um programa de alimentação escolar. Hlg Alim. 1999; 12: $13-18$. 
Marin VA, Lemos AA, Freitas El. Detecção de patógenos presentes nos alimentos: a falta de padronização e validação de métodos moleculares no Brasil. Hig Alim. 2006;20:46-50.

Marques MCC. As práticas sanitárias como objeto de pesquisa da história. In: CECOVISA - Centro Colaborador em Vigilância Sanitária. Vigilância Sanitária: textos e contextos. São Paulo: CECOVISA, 2005.

Marques SMM, Tuma RB. Impacto de um programa de intervenção nutricional sobre o perfil antropométrico de adultos em uma empresa de construção civil. In: Sociedade Brasileira de Alimentação e Nutrição - VI Congresso Nacional da Sociedade Brasileira de Alimentação e Nutrição, 2001, Florianópolis. Resumos. Florianópolis: SBAN, 2001.

Martins EA. Avaliação da eficiência dos fornos combinados e convencionais elétricos na inativação de Salmonella sp [dissertação de mestrado]. São Paulo: Faculdade de Ciências Farmacêuticas da USP; 2000.

Martins CG. Irradiação de grão (Nasturtium oficinallis) minimamente processado: aspectos microbiológicos e sensoriais [dissertação de mestrado]. São Paulo: Faculdade de Ciências Farmacêuticas; 2004.

Massaguer PR. Microbiologia dos processos alimentares. São Paulo: Varela, 2006.

Matsumura EM. Perspectivas para a conservação e reuso da água na indústria de alimentos - estudo de uma unidade de processamento de frangos [dissertação de mestrado]. São Paulo: Escola Politécnica; 2007. 
Mayer S, Stirling A. Finding a precautionary approach to technological developments - lessons for the evaluation pf GM crops. Journal of Agricultural and Environmental Ethics. 2002; 15: 57 - 71.

Mendes CM. Disposição de pagar por alimentos seguros: o caso dos hortifrutícolas sem resíduos de agrotóxicos [tese de doutorado]. São Paulo: Escola Superior de Agricultura "Luiz de Queiroz"; 2002.

Mendonça ACC. Transgênicos: opinião de professores e alunos de nível médio da área de nutrição [dissertação de mestrado]. São Paulo: Escola Superior de Agricultura "Luiz de Queiroz"; 2005.

Mendonça KS, Araújo MR. Conformidade de rotulagem de alimentos para fins especiais. Hig Alim. 2006; 21: 427 - 428.

Mezomo IB. Os serviços de alimentação - planejamento e administração. 5 ed. São Paulo: Manole, 2002.

Miguel M, Lamardo LCA, Galvão MS, Navas AS, Garbelotti ML, Branciforte M. Legislação em higiene alimentar e suas aplicações. Hig Alim. 2000;14:4449.

Ministério da Saúde. Secretaria de Atenção à Saúde. Coordenação-Geral da Política de Alimentação e Nutrição. Guia alimentar para a população brasileira: Promovendo a alimentação saudável. Edição especial. Brasília (DF): Ministério da Saúde; 2005.

Miranda DC. Relato de experiência - vigilância da qualidade da água para consumo humano: a experiência de Vitória (ES). REVISA. 2005; 1: 303 306. 
Mondini L, Monteiro CA. Relevância epidemiológica da desnutrição e da obesidade em distintas classes sociais: métodos de estudo e aplicação à população brasileira. O Mundo da Saúde. 2001; 25: 125 - 131.

Monteiro CA, Mondini L, Costa RBL. Mudanças na composição e adequação nutricional da dieta familiar nas áreas metropolitanas do Brasil (1988 1996). Rev Saúde Pública. 2000; 34: 251 - 258.

Moraes IA, Figueiredo M, Frensch FB, Nigris ED. Condições higiênicosanitárias na comercialização de alimentos em shoppings da cidade do Rio de Janeiro. Hig Alim. 2005; 19: 35 - 39.

Moreno MLG. Avaliação do efeito combinado do processo de irradiação e da embalagem em diferentes atmosferas na qualidade microbiológica e sensorial de carne bovina (Longissimus dorsi) fresca refrigerada e congelada [tese de doutorado]. São Paulo: Faculdade de Ciências Farmacêuticas; 2001.

Nardin MS. Conservação de cogumelos comestíveis (Pleurotus sajor-caju) por acidificação e processamento térmico e por desidratação [dissertação de mestrado]. São Paulo: Escola Superior de Agricultura "Luiz de Queiroz"; 1999.

Nascimento AR, Marques CMP. Avaliação microbiológica de saladas "in natura", oferecidas em restaurantes self-service de São Luiz, MA. Hig Alim. 1998; $12: 41-43$.

Nero LA. Listeria monocytogenes e Salmonella spp. em leite cru produzido em quatro regiões leiteiras no Brasil: ocorrência e fatores que interferem na sua detecção [tese de doutorado]. São Paulo: Faculdade de Ciências Farmacêuticas; 2005. 
Neto GV, Marques MCC, Figueiredo AM. Vigilância sanitária no Brasil. In: Campos GWS, Minayo MCS, Akerman M, Drumond Júnior M, de Carvalho YM. Tratado de saúde coletiva. São Paulo: FIOCRUZ, 2006.

Nogueira MD. Análise de perigos e pontos críticos de controle no processamento de farinha de trigo integral [dissertação de mestrado]. São Paulo: Faculdade de Ciências Farmacêuticas; 2000.

Oliveira DAG. Avaliação química, nutricional e sensorial de uma mistura à base de farinhas de arroz, banana e mandioca, enriquecida com outras fontes protéicas [dissertação de mestrado]. São Paulo: Escola Superior de Agricultura "Luiz de Queiroz"; 1997.

Oliveira IB, Sabato SF. Dissemination of the food irradiation of the food irradiation process on different opportunities in Brazil. Radiation Physics and Chemistry, Oxford. 2000; 21: 493 - 497.

Oliveira JTGSB. Melhor dose e dose econômica de TBHQ nos óleos de milho e canola [dissertação de mestrado]. São Paulo: Escola Superior de Agricultura "Luiz de Queiroz"; 2003.

Oliveira RPS. Condições microbiológicas e avaliação da pasteurização em amostras de leite comercializadas no município de Piracicaba - SP [dissertação de mestrado]. São Paulo: Escola Superior de Agricultura "Luiz de Queiroz"; 2005.

Oliveira AFL, Bueno PHS, Machado MM, Oliveira RBP, Pinto FC, Correia RF. Efeitos da radiação gama sobre a força de cisalhamento e perdas de peso ao cozimento de peito de frango. Hig Alim. 2006; 21: 16. 
Oliveira CAF. Qualidade do leite no processamento de derivados. In: Germano PML, Germano MIS. Higiene e vigilância sanitária de alimentos. 3 ed. São Paulo: Manole, 2008.

Olivo R. Carne PSE em frangos [tese de doutorado]. São Paulo: Faculdade de Ciências Farmacêuticas; 1999.

Ornelas CBD, Gonçalves MPJ, Silva PR, Martins RT. Atitude do consumidor frente à irradiação de alimentos. Ciência e Tecnologia de Alimentos. 2006; 26: $211-213$.

Panetta JC. Globalização e consumo seguro de alimentos. Hig Alim. 2004; 18:04-05.

Panetta JC. Mercado de alimentos: os desafios para 2008. Hig Alim. 2008; 21: $03-04$.

Panza SGA, Brotherhood R, Andreotti A, Rezende C, Balleroni FH, Paroschi VHB. Avaliação das condições higiênico-sanitárias durante a manipulação dos alimentos, em um restaurante universitário, antes e depois do treinamento dos manipuladores. Hig Alim. 2006; 20: 15 - 19.

Parlamento Europeu - Comissão do Meio Ambiente, da Saúde Pública e da Política do Consumidor - Comissão relativa a alimentos e ingredientes alimentares autorizados para tratamento por radiação ionizante na comunidade européia [homepage da internet]. [acesso em 13 junho 2008]. Disponível em: http://www.europarl.eu.int/meedocs/commetteess/envi/20021104/470306pt.pdf 
Parmigiani MPCVD. Comparação de técnicas de mineralização para determinação de chumbo em alimentos destinados a população infantil [dissertação de mestrado]. São Paulo: Faculdade de Ciências Farmacêuticas; 1993.

Pastore CAA. A saúde do coração na alimentação. Hig Alim. 1998;12: 13.

Paula P, Rodrigues PSS, Tórtora JCO, Uchoa CMA, Farage S. Contaminação microbiológica e parasitológica em alfaces (Lactuca sativa) de restaurantes self-service, de Niterói, RJ. Rev Soc Bras Medicina Tropical. 2003; 36: $535-537$.

Paz MT, Gómez H, Rodriguez Z, Banguela S, Casanova R, Alfonso M. Puntos críticos em la elaboración de la crema helada. Alimentaria. 1999;302:77-81.

Pedro SCM. Avaliação da qualidade higiênico-sanitária dos locais de venda e de amostras de queijo minas meia cura, comercializado na cidade de São Paulo [dissertação de mestrado]. São Paulo: Faculdade de Saúde Pública; 2003.

Pedro SCM, Matté GR, Germano PML, Matté MH. Aspectos sanitários da comercialização do queijo minas meia cura no Município de São Paulo. REVISA. 2005; 1: 246 - 253.

Peixoto ST, Pedreiro JD, Esteves T, Pereira CRH. A vigilância sanitária e a municipalização: atribuições e competências. Hig Alim. 2006;20:25-33.

Penha Filho ML, Leal WM, Militao TAMF, Pereira ULT. Comparação entre o tipo de registro, origem e porte dos estabelecimentos que comercializam produtos de origem animal nos municípios baianos. Hig Alim. 2006; 21: 423. 
Penteado SR. Uso de atmosfera modificada e embalagens ativas, na conservação do figo Roxo de Valinhos (Ficus carica L.) [dissertação de mestrado]. São Paulo: Escola Superior de Agricultura "Luiz de Queiroz"; 1998.

Perdigão MLPG. Avaliação do processo de sanificação química na linha de produção de saladas cruas em um restaurante industrial [dissertação de mestrado]. São Paulo: Escola Superior de Agricultura "Luiz de Queiroz"; 2004.

Pereira AAF. Avaliação de condições de consumo de sardinha fresca, descongelada e processada, através de substâncias que reagem com o ácido tiobarbitúrico e do nitrogênio de bases voláteis totais [dissertação de mestrado]. São Paulo: Faculdade de Ciências Farmacêuticas; 2004.

Pinelli LLO, Araújo WMC. Produção, qualidade e segurança sanitária de vegetais minimamente processados. Hig Alim. 2006; 20: 55 - 60.

Piovesan MF. A construção política da Agência Nacional de Vigilância Sanitária [dissertação de mestrado]. Rio de Janeiro: Escola Nacional de Saúde Pública / Fundação Oswaldo Cruz; 2002.

Pipitone MAP. Educação para o controle de alimentos. Hig Alim. 2005; 19: $18-23$.

Pospissil RT. Dieta ovo-lacto-vegetariana: aspectos positivos, negativos e seu impacto na saúde. In: Associação Brasileira de Nutrição - XVII Congresso Brasileiro de Nutrição da Associação Brasileira de Nutrição, 2002, Porto Alegre. Anais. Porto Alegre: ASBRAN, 2002.

Ramos RZ, Cunha MGA da, Schmidt V. Boas práticas de fabricação em indústria de panificação: relato de caso. Hig Alim. 2005; 19: 34 - 38. 
Ratti RP. Listeria monocytogenes em alimentos fatiados e equipamentos: ocorrência, formação de biofilme e controle [dissertação de mestrado]. São Paulo: Faculdade de Ciências Farmacêuticas; 2006.

Ratto AT. Tabela Brasileira de Composição de Alimentos (TBCA-USP) apoio para determinar a qualidade das informações nutricionais em rótulos de alimentos [dissertação de mestrado]. São Paulo: Instituto de Química; 2005.

Raymundo G, Pereira G. Prevalência e sobrepeso e avaliação da composição corporal dos pacientes atendidos pelo ambulatório de atenção dietética pela clínica escola de nutrição do Unicenp. In: Associação Brasileira de Nutrição - XVII Congresso Brasileiro de Nutrição da Associação Brasileira de Nutrição, 2002, Porto Alegre. Anais. Porto Alegre: ASBRAN, 2002.

Recena MCP, Caldas ED. Percepção de risco, atitudes e práticas no uso de agrotóxicos entre agricultores de Culturama, MS. Rev Saúde Pública. 2008; 42: $294-301$.

Resende RS. Hábito de higienização das mãos antes das refeições em restaurantes no município de Vitória/ES [dissertação de mestrado]. São Paulo: Faculdade de Saúde Pública; 2005.

Resende RS, Spinola AWP, Matté GR. Hábito de higienização das mãos antes das refeições em restaurantes no município de Vitória (ES). REVISA. 2006; 2: $11-15$.

Rey L. Planejar e redigir trabalhos científicos. São Paulo: Edigar Blücher, 1993. 
Ribeiro VF. Avaliação do estado nutricional dos colaboradores de um resort internacional da Bahia. In: Anais do $6^{\circ}$. Congresso Internacional de Gastronomia, Nutrição e Qualidade e Vida; 2005; São Paulo, BR. São Paulo: Núcleo Atualização Científica em Nutrição, 2005a.

Ribeiro VF. Análise microbiológica de equipamentos em UAN. In: Anais do $6^{\circ}$. Congresso Internacional de Gastronomia, Nutrição e Qualidade e Vida; 2005; São Paulo, BR. São Paulo: Núcleo Atualização Científica em Nutrição, 2005b.

Ribeiro VF. O jogo como forma de aprendizagem no treinamento de manipuladores. In: Anais do $6^{\circ}$. Congresso Internacional de Gastronomia, Nutrição e Qualidade e Vida; 2005; São Paulo, BR. São Paulo: Núcleo Atualização Científica em Nutrição, 2005c.

Rocha MAA, Sousa QHF, Vasques MV, Alcântara PFP. Irradiação de alimentos. $\mathrm{O}$ uso de alimentos irradiados no tratamento de pacientes com baixa imunidade. [homepage da internet]. Brasília, 2007 [acesso em 26 agosto 2008]. Disponível em: http://www.conter.gov.br/portal/trabalhoscientificos/irradiacao.pdf

Rodrigues RSM. Alimentos transgênicos. In: Germano PML, Germano MIS. Higiene e vigilância sanitária de alimentos. 3 ed. São Paulo: Manole, 2008.

Rojas MVR. Caracterização por meio de métodos moleculares de cepas ambientais de Vibrio parahaemolyticus isoladas no Brasil [dissertação de mestrado]. São Paulo: Faculdade de Saúde Pública; 2007.

Rosen G. Uma história da saúde pública. 2 ed. Rio de Janeiro: Hucitec, 1994. 
Rozenfeld S. Fundamentos da vigilância sanitária. Rio de Janeiro: Fiocruz, 2000.

Salgado RL, Costa JCB, Conte-Junior CA, Fernández M, Mano SB. Alteraciones microbiológicas, químicas y sensoriales del pargo (Pagrus pagrus) envasado em atmosfera modificada. HIg Alim. 2006; 21: 47.

Santaella SRR. Controle de soluções sanificantes por meio do potencial de óxido-redução em alface americana minimamente processada [tese de doutorado]. São Paulo: Faculdade de Saúde Pública; 2007.

Santaella SRR, Psillakis CN, Almeida CG, Okazaki MM, Cabral NT, Quarentel SS, Mesquita F, Santos TBA, Nitzsche T. Hortifrutícolas minimamente processadas: necessidade de legislação específica para atender às inovações tecnológicas e à inocuidade alimentar. In: Anais do $3^{\circ}$ Simbravisa - Simpósio brasileiro de vigilância sanitária. Florianópolis; 2006.

Santos A, Bittencourt RR. Perspectivas para a construção de uma nova consciência coletiva que conceba a vigilância sanitária como rede: REDEVISA. REVISA. 2005;1:133-140.

Santos RJ. Efeito do armazenamento de polpas de frutas congeladas sobre os teores de flavonóides, vitamina $\mathrm{C}$ e atividade antioxidantes [dissertação de mestrado]. São Paulo: Faculdade de Ciências Farmacêuticas; 2005.

Sawaya AL et al. Mild, stunting is associated with higher susceptibility to the effects of high fat diets: studies in a shantytown population in São Paulo, Brazil. Journal Nutrition. 1998; 128: 415S-420S. 
Schlindwein MM. Influência do custo de oportunidade do tempo da mulher sobre o padrão de consumo alimentar das famílias brasileiras [tese de doutorado]. São Paulo: Escola Superior de Agricultura "Luiz de Queiroz"; 2006.

Schlindwein MM. Análise da influência de alguns fatores socioeconômicos e demográficos no consumo domiciliar de carnes no Brasil. RER. 2006;44:549572(a).

Schlundt J. New directions in foodborne disease prevention. Int Journal of Food Microbiology. 2002; 78:3-17.

Schmitz EF. Papel social da universidade: concepção de novo modelo. Estudos Leopoldenses. 1995; 31: 19 - 29.

Sichieri R et al. Relação Entre o Consumo Alimentar e Atividade Física Com o Índice de Massa Corporal em Funcionários Universitários. Revista Nutrição Campinas. 1998; 11: 185 - 195.

Silva C. Merenda escolar: levantamento das condições higiênico-sanitária dos locais de preparação e dos manipuladores em escolas da rede estadual de ensino de São Paulo, SP [dissertação de mestrado]. São Paulo: Faculdade de Saúde Pública; 2002.

Silva EA, Stefoni S, Maluf YT, Santos IM, Corrado MC, Ferreira MAM. Avaliação microbiológica de utensílios de cozinha, mãos de manipuladores e refeições servidas em restaurantes do tipo self-service no município de São Paulo. REVISA. 2006; 2: 11 - 15. 
Silva JO, Capuano DM, Takayanagui OM, Júnior Giacometti E. Enteroparasitoses e onicomicoses em manipuladores de alimentos do município de Ribeirão Preto, SP, Brasil. Rev Bras Epidemiol. 2005; 8: 385 392.

Silva Jr EA. Manual de controle higiênico-sanitário em serviços de alimentação. 5 ed. São Paulo: Varela, 2005.

Silva LJB, Souza ML. Avaliação higiênico-sanitária do preparo da merenda escolar, no Colégio de Aplicação da Universidade Federal do Acre, em Rio Branco. Hig Alim. 2007; 21: 16 - 22.

Silva, ML. Pesquisa de Aeromonas spp., Vibrio spp. e da qualidade sanitária de peixes comercializados na cidade de São Paulo [dissertação de mestrado]. São Paulo: Faculdade de Saúde Pública; 2007.

Silva ZP, Coroa ML. Vigilância sanitária: um histórico discursivo. REVISA. 2005;1:3-15.

Simões MJS. Recursos humanos em vigilância sanitária: enfocando o município de Rio Claro (SP). REVISA. 2005;1:217-226.

Siqueira AAZC. Efeitos da irradiação e refrigeração na qualidade e no valor nutritivo da Tilápia (Oreochromis niloticus) [dissertação de mestrado]. São Paulo: Escola Superior de Agricultura “Luiz de Queiroz”; 2001.

Siqueira LM, Delú MAF, Sbampato CG, Mendonça AT. Ocorrência de gastroenterites relacionadas à ingestão e manipulação inadequada de alimentos. Hig Alim. 2006;20:34-36. 
Siqueira IMC, Moura AFP, Girão FGF, Santos WLM. Avaliação microbiológica de saladas cruas e cozidas servidas em restaurantes industriais da grande Belo Horizonte. Hig Alim. 1997; 11: 36 - 39.

Soares CM. Análise da qualidade higiênico-sanitária do pescado servido cru em restaurantes do tipo fast-food do município de São Paulo - SP [dissertação de mestrado]. São Paulo: Faculdade de Saúde Pública; 1999.

Soares CM, Germano MIS, Spolaore AJG, Germano PML. Irradiação de alimentos. In: Germano PML, Germano MIS. Higiene e vigilância sanitária de alimentos. 3 ed. São Paulo: Manole, 2008.

Soccol MCH. Otimização da vida útil da tilápia cultivada (Oreochromis niloticus), minimamente processada e armazenada sob refrigeração [dissertação de mestrado]. São Paulo: Escola Superior de Agricultura "Luiz de Queiroz"; 2003.

Soto FRM, Risseto MR, Balian SC, Pinheiro SR, Telles EO, Cazzola CPB, Maldonado AG. Resultados da ação da vigilância sanitária de alimentos em um supermercado do estado de São Paulo. Hig Alim. 2006;20:21-25.

Souza AMAF, Marques SB, Vignola SR. Formação de recursos humanos para o Sistema Nacional de Vigilância Sanitária: uma breve discussão sobre questões pedagógicas. In: CECOVISA - Centro Colaborador em Vigilância Sanitária. Vigilância Sanitária: textos e contextos. São Paulo: CECOVISA, 2005.

Souza LHL. A manipulação adequada dos alimentos: fator de contaminação. Hig Alim. 2006;20:32-39.

Stolte D, Tondo EC. Análise de perigos e pontos críticos de controle em uma unidade de alimentação e nutrição. Hig Alim. 2001;15:41-49. 
Tabai KC. Análise do controle de alimentos no Brasil: da intervenção governamental à participação de consumidores e suas organizações. Hig Alim. 2002;16:22-25.

Taipina MS, Rodas MAB, Garbelotti Ml, Mastro NL. Avaliação do efeito da radiação de $60 \mathrm{CO}$ sobre propriedades nutricionais e sensoriais de biscoitos integrais. Hig Alim. 2006; 21: 425.

Takayanagui OM, Oliveira CD, Bergamini AMM, Capuano DM, Okino MHT, Febrônio LHP, Castro e Silva AAMC, Oliveira MA, Ribeiro EGA, Takayanagui AMM. Fiscalização de verduras comercializadas no município de Ribeirão Preto, SP. Rev Soc Bras Medicina Tropical. 2001; 34: 37 - 41.

Tardido AP, Falcão MC. O impacto da modernização na transição nutricional e obesidade. Rev Bras Nutr Clin. 2006; 21: 117 - 124.

Tavolaro P. Avaliação de metodologias rápidas para a determinação da qualidade microbiológica e da vida de prateleira de leite de cabra pasteurizado e congelado [dissertação de mestrado]. São Paulo: Faculdade de Ciências Farmacêuticas; 2000.

Teixeira CF. Promoção e vigilância da saúde no contexto da regionalização da assistência à saúde no SUS. Cadernos de Saúde Pública. 2002; 18: 153162.

Tilly C. O acesso desigual ao conhecimento científico. Tempo Social. 2006; 18: $47-63$.

Trigueiro MGS. A comunidade científica, o Estado e as universidades, no atual estágio de desenvolvimento científico tecnológico. Sociologias. 2001; 6: $30-50$. 
Trindade AA. Subsídios para implementação do Sistema de Análise de Perigos e Pontos Críticos de Controle - APPCC em lactário [dissertação de mestrado]. São Paulo: Escola Superior de Agricultura "Luiz de Queiroz"; 2006.

Trindade JCS, Prigenzi LS. Instituições universitárias e produção do conhecimento. São Paulo em Perspectiva. 2002; 16: 9 - 14.

Valente D, Passos ADC. Avaliação higiênico-sanitária e físico-estrutural dos supermercados de uma cidade do Sudeste do Brasil. Rev Bras Epidemiol. 2004;7:80-87.

Vello KRMO, Freire MMM, Schattan RB, Gollucke APB. Análise de pontos críticos em certas preparações servidas em quiosques de praia. Hig Alim. 2005;19:37-44.

Victaliano MFPJ. Pesquisa de satisfação do consumidor utilizando-se o método kano: uma abordagem para produtos alimentícios recém lançados [dissertação de mestrado]. São Paulo: Faculdade de Ciências Farmacêuticas; 2004.

Vieira HRA. Legislação Brasileira sobre alimentos e os crimes contra a saúde pública. Hig Alim. 1993;7:35-39.

Vieira IFR, Gonçalves CG, Leal AS, Machado EV, Krambrock K. Efeito da radiação gama sobre a qualidade da pimenta do reino. Hig Alim. 2007; 21: $36-40$.

Vieites RL, Evangelista RM, Manoel L, Moreira GC. Efeito da radiação gama na sanitização do mamão formosa minimamente processado. Hig Alim. 2007; $21: 71-76$. 
Villares LF. A rotulagem dos alimentos transgênicos no Brasil [dissertação de mestrado]. São Paulo: PROCAM; 2004.

Vitti MCD. Aspectos fisiológicos, bioquímicos e microbiológicos em beterrabas minimamente processadas [dissertação de mestrado]. São Paulo: Escola Superior de Agricultura "Luiz de Queiroz"; 2003.

Zanão CFP. Características físico-químicas e sensoriais do arroz (Oryza sativa $L$.) irradiado e o efeito no desenvolvimento de Sitophilus oryzae $L$. [dissertação de mestrado]. São Paulo: Escola Superior de Agricultura "Luiz de Queiroz"; 2007.

Zanon CA. Avaliação dos procedimentos de higienização de equipamentos, utensílios, mobiliário e mãos de funcionários pertencentes a uma unidade de alimentação e nutrição [dissertação de mestrado]. São Paulo: Faculdade de Ciências Farmacêuticas; 1999.

Zanutto ME. Comparação entre a biodisponibilidade do beta-caroteno sintético e de fonte natural (couve-manteiga): papel de fibra alimentar em animais de laboratório [dissertação de mestrado]. São Paulo: Faculdade de Ciências Farmacêuticas; 2000. 
AN패요 


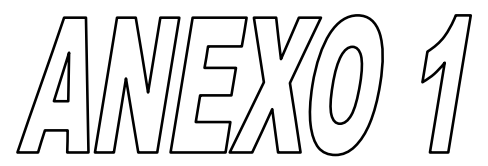

Referências bibliográficas das teses e dissertações utilizadas na pesquisa 


\section{Referências $^{2}$}

01. (93M01) Wettstein ASR. Levantamento e avaliação da qualidade microbiológica de alimentos processados em cozinhas industriais no estado de São Paulo, nos anos de 1989 e 1990 [dissertação de mestrado]. São Paulo: Escola Superior de Agricultura "Luiz de Queiroz"; 1993.

02. (93M02) Verruma MR. Avaliação química, nutricional e sensorial do leite de búfala e derivados em comparação aqueles de leite de vaca [dissertação de mestrado]. São Paulo: Escola Superior de Agricultura "Luiz de Queiroz"; 1993.

03. (93M03) Aizpurua ICM. Mercúrio em cação - quantificação e efeito de salga e dessalga da cisteína [dissertação de mestrado]. São Paulo: Faculdade de Ciências Farmacêuticas; 1993.

04. (93M04) Chicourel EL. Mercúrio em pescado - quantificação e o efeito do preparo para o consumo [dissertação de mestrado]. São Paulo: Faculdade de Ciências Farmacêuticas; 1993.

05. (93M05) Santos ALM. Resistência térmica de Clostridium perfringens durante o processamento de carnes em restaurantes industriais [dissertação de mestrado]. São Paulo: Faculdade de Ciências Farmacêuticas; 1993.

06. (93M06) Colombo PT. Influência de diferentes temperaturas e tempos de armazenamento sobre a viabilidade e resistência térmica de esporos de Bacillus stereathermophilus ATCC 7953 [dissertação de mestrado]. São Paulo: Faculdade de Ciências Farmacêuticas; 1993.

${ }^{2}$ Apresentadas Segundo o Guia de Apresentação de Teses $2^{\mathrm{a}}$. ed - Biblioteca/CIR. São Paulo: FSP/USP; 2006. 
07. (93M07) Parmigiani MPCVD. Comparação de técnicas de mineralização para determinação de chumbo em alimentos destinados a população infantil [dissertação de mestrado]. São Paulo: Faculdade de Ciências Farmacêuticas; 1993.

08. (93M08) Saad SMI. Aeromonas do grupo A. hydrophila em amostras de hortaliças comercializadas na cidade de São Paulo [dissertação de mestrado]. São Paulo: Faculdade de Ciências Farmacêuticas; 1993.

09. (94M01) Bianchini R. Carotenóides dos pimentões amarelos (capsicum annuum, I). Caracterização e verificação de mudanças com o cozimento [dissertação de mestrado]. São Paulo: Faculdade de Ciências Farmacêuticas; 1994.

10. (94M02) Gomes HA. Ocorrência de Staphylococcus aureus e produção de enterotoxinas por linhagens isoladas a partir de leite cru, leite pasteurizado tipo C e queijo minas frescal, comercializados em Piracicaba-SP [dissertação de mestrado]. São Paulo: Escola Superior de Agricultura "Luiz de Queiroz"; 1994.

11. (94M03) Machinski Junior, M. Métodos analíticos para a determinação de patulina em suco de maçã [dissertação de mestrado]. São Paulo: Faculdade de Ciências Farmacêuticas; 1994.

12. (94M04) Avila CR. Pesquisa de Salmonella spp. Em leite cru, leite pasteurizado tipo $\mathrm{C}$ e queijo minas frescal comercializados no município de Piracicaba-SP [dissertação de mestrado]. São Paulo: Escola Superior de Agricultura "Luiz de Queiroz"; 1994.

13. (95M01) Blumer L. Efeito da radiação gama e do tratamento térmico na conservação do suco natural de maçã (malus domestica), cv. Gala [dissertação de mestrado]. São Paulo: Centro de Energia Nuclear e Agricultura; 1995. 
14. (95M02) Tassinari, AR. Sobrevivência de Salmonella typhimurium em alimentos inoculados experimentalmente e aquecidos por microondas [dissertação de mestrado]. São Paulo: Faculdade de Ciências Farmacêuticas; 1995.

15. (95D03) Zenebon O. Determinação de mercúrio: uso de 'H IND.2"O IND.2'/'H IND.2's'O IND.4' na preparação de amostras em alimentos e estudo sistemático de oxidantes na preparação de amostras de urina [tese de doutorado]. São Paulo: Instituto de Química; 1995.

16. (95M04) Veiga MCM. Condições higiênico-sanitárias de alguns alimentos para o consumo, mantidos em vitrines aquecidas de estabelecimentos varejistas da cidade de São Paulo, SP, 1992 a 1994 [dissertação de mestrado]. São Paulo: Faculdade de Medicina Veterinária e Zootecnia; 1995.

17. (95D05) Destro MT. Listeria monocytogenes em camarão (penaeus brasiliensis): marcadores sorológicos e genéticos no monitoramento de sua disseminação em uma unidade processadora de pescado [tese de doutorado]. São Paulo: Faculdade de Ciências Farmacêuticas; 1995.

18. (95M06) Tiglea P. Cromo em alimentos [dissertação de mestrado]. São Paulo: Instituto de Química; 1995.

19. (95M07) Nogueira DF. Resistência térmica de Bacillus cereus em solução tampão fosfato e em arroz [dissertação de mestrado]. São Paulo: Faculdade de Ciências Farmacêuticas; 1995.

20. (95M08) Martins DI. Destilação a vapor e cromatografia em fase gasosa na determinação de resíduos de herbicidas em alimentos [dissertação de mestrado]. São Paulo: Faculdade de Ciências Farmacêuticas; 1995. 
21. (95D09) Queiroz JC. Avaliação sanitária do leite cru distribuído nos municípios de Juquitiba e Itapecerica da Serra, São Paulo - 1990-1992 [tese de doutorado]. São Paulo: Faculdade de Saúde Pública; 1995.

22. (96M01) Cruz VR. Variação do pH, acidez titulável e da microbiota do leite de vaca tratado em forno microondas [dissertação de mestrado]. São Paulo: Escola Superior de Agricultura "Luiz de Queiroz"; 1996.

23. (96M02) Moreno I. Ocorrência e caracterização de bacteriocinas de lactococos e sua utilização no processamento de queijo minas frescal [dissertação de mestrado]. São Paulo: Faculdade de Ciências Farmacêuticas; 1996.

24. (96M03) Stefanovitz AHO. Distribuição da contaminação com aflatoxinas nos tipos de grãos de amendoim (arachis hypogaea I.), definidos pela classificação oficial do Brasil [dissertação de mestrado]. São Paulo: Escola Superior de Agricultura "Luiz de Queiroz"; 1996.

25. (96M04) Boghossian AR. Uso de carragenas na fabricação do queijo tipo minas frescal [dissertação de mestrado]. São Paulo: Escola Superior de Agricultura "Luiz de Queiroz"; 1996.

26. (96M05) Melo Neto, ML. Uso de protetores e refrigeração na conservação da manga (mangifera indica I.) Cv. Palmer [dissertação de mestrado]. São Paulo: Escola Superior de Agricultura "Luiz de Queiroz"; 1996.

27. (96M06) Tavares SG. Avaliação das condições microbiológicas de leite pasteurizado tipos a, b e c, comercializados na cidade de piracicaba, SP [dissertação de mestrado]. São Paulo: Escola Superior de Agricultura "Luiz de Queiroz"; 1996.

28. (96M07) Barretto ACS. Efeito da adição de antioxidantes naturais na oxidação lipídica e cor de carne de frango e derivado [dissertação de mestrado]. São Paulo: Faculdade de Ciências Farmacêuticas; 1996. 
29. (96M08) Duarte M. Determinação de nitratos e nitritos em leite e em misturas com soro [dissertação de mestrado]. São Paulo: Faculdade de Ciências Farmacêuticas; 1996.

30. (96M09) Moreno MLG. Estudo da ocorrência de Vibrio vulnificus em alimentos de origem marinha e de alguns fatores de virulência das cepas isoladas [dissertação de mestrado]. São Paulo: Faculdade de Ciências Farmacêuticas; 1996.

31. (96M10) Nori MA. Produção de microcápsulas de acido cítrico para utilização em produtos cárneos [dissertação de mestrado]. São Paulo: Faculdade de Ciências Farmacêuticas; 1996.

32. (97M01) Oliveira DAG. Avaliação química, nutricional e sensorial de uma mistura à base de farinhas de arroz, banana e mandioca, enriquecida com outras fontes protéicas [dissertação de mestrado]. São Paulo: Escola Superior de Agricultura "Luiz de Queiroz"; 1997.

33. (97M02) Ramos e Silva, ET. Fabricação artesanal de mozzarella elaborada com leite cru de búfala. Estudo da contaminação microbiológica associada à manipulação em produção manual ou parcialmente mecanizada [dissertação de mestrado]. São Paulo: Faculdade de Medicina Veterinária e Zootecnia; 1997.

34. (97D03) De Martinis ECP. Isolamento de bactérias láticas produtoras de bacteriocina e sua aplicação no controle de Listeria monocytogenes em lingüiça frescal [tese de doutorado]. São Paulo: Faculdade de Ciências Farmacêuticas; 1997.

35. (97D04) Saad SMI. Comportamento de Escherichia coli enterohemorrágica 0157:H7 frente a bactérias autoctones em carne bovina moída [tese de doutorado]. São Paulo: Faculdade de Ciências Farmacêuticas; 1997. 
36. (97M05) Santos AF. Determinação da dose de radiação gama para a destruição de Salmonella spp. em carne de frango [dissertação de mestrado]. São Paulo: Faculdade de Ciências Farmacêuticas; 1997.

37. (97M06) Pinheiro LG. Avaliação do método fluorognico para enumeração rápida de Escherichia coli em carnes e produtos cárneos [dissertação de mestrado]. São Paulo: Faculdade de Ciências Farmacêuticas; 1997.

38. (97M07) Santos MGB. Termoresistência de esporos de Bacillus stearothermophilus ATCC 7953 após diferentes condições de armazenamento [dissertação de mestrado]. São Paulo: Faculdade de Ciências Farmacêuticas; 1997.

39. (97M08) Carmo LF. Resistência térmica de esporos de Bacillus cereus IAL 55 condicionados em diferentes atividades de água, frente a vapor superaquecido a $140^{\circ} \mathrm{C}$ e atividade de água média $=0,264$ [dissertação de mestrado]. São Paulo: Escola Superior de Agricultura "Luiz de Queiroz"; 1997.

40. (97M10) Obregon CL. Variação do teor de cromo durante o processo de elaboração de massas alimentícias [dissertação de mestrado]. São Paulo: Faculdade de Ciências Farmacêuticas; 1997.

41. (97M11) Moura ML. Efeitos de níveis de 'O IND.2' e C'O IND.2' na conservação pós-colheita de tomate (Lycopersicon esculentum) cv. Agriset colhido em estádio intermediário de maturidade [dissertação de mestrado]. São Paulo: Escola Superior de Agricultura “Luiz de Queiroz"; 1997.

42. (98M01) Marques PAHF. Avaliação de metodologias para o isolamento de Escherichia coli 0157:H7 de carne bovina moída. Ocorrência de Escherichia coli 0157:H7 em hambúrgueres [dissertação de mestrado]. São Paulo: Faculdade de Ciências Farmacêuticas; 1998. 
43. (98M02) Ferrari CKB. Oxidação lipídica em salsichas comercializadas nos sacolões municipais de São Paulo [dissertação de mestrado]. São Paulo: Faculdade de Saúde Pública; 1998.

44. (98M03) Cardarelli HR. Conservação do extrato fluido de castanha-do-pará (Bertholletia excelsa), com ênfase no desenvolvimento microbiano, acidez titulável e pH [dissertação de mestrado]. São Paulo: Escola Superior de Agricultura "Luiz de Queiroz"; 1998.

45. (98D04) Penteado SR. Uso de atmosfera modificada e embalagens ativas, na conservação do figo Roxo de Valinhos (Ficus carica L.) [dissertação de mestrado]. São Paulo: Escola Superior de Agricultura "Luiz de Queiroz"; 1998.

46. (98D05) Sant'ana HMP. Análise de vitaminas do complexo B em carnes preparadas em serviço de alimentação [tese de doutorado]. São Paulo: Faculdade de Ciências Farmacêuticas; 1998.

47. (98D06) Bianchini R. Análise de vitaminas e beta-caroteno em leite bovino [tese de doutorado]. São Paulo: Faculdade de Ciências Farmacêuticas; 1998.

48. (98D07) Smiderle OJ. Tratamento inseticida e qualidade de sementes de milho durante o armazenamento [tese de doutorado]. São Paulo: Escola Superior de Agricultura "Luiz de Queiroz"; 1998.

49. (98D08) Reis RB. Padronização de um teste imunoenzimático para detecção de Salmonella em alimentos [tese de doutorado]. São Paulo: Faculdade de Ciências Farmacêuticas; 1998.

50. (98D09) Silva WP. Caracterização fenotípica e genotípica de cepas de S.aureus isoladas de leite de vacas com mastite subclínica e de outras fontes em propriedades produtoras de leite [tese de doutorado]. São Paulo: Faculdade de Ciências Farmacêuticas; 1998. 
51. (98D10) Pinto PSA. Diagnóstico imunológico da cisticircose suína como contribuição à inspeção de carnes [tese de doutorado]. São Paulo: Faculdade de Saúde Pública; 1998.

52. (98M11) Zovico C. Avaliação de processos de seleção na descontaminação de amendoim contaminado com aflatoxinas [dissertação de mestrado]. São Paulo: Escola Superior de Agricultura "Luiz de Queiroz"; 1998.

53. (99M01) Soares CM. Análise da qualidade higiênico-sanitária do pescado servido cru em restaurantes do tipo fast-food do município de São Paulo SP [dissertação de mestrado]. São Paulo: Faculdade de Saúde Pública; 1999.

54. (99M02) Chirinos RRO. Determinação da dose de radiação gama para a destruição de Escherichia coli 0157:H7 em hambúrguer bovino [dissertação de mestrado]. São Paulo: Faculdade de Ciências Farmacêuticas; 1999.

55. (99M03) Rodrigues DA. Listeria sp e Listeria monocytogenes em indústria processadora de nuggets de frango: estudo de ocorrência e avaliação de metodologias de análise [dissertação de mestrado]. São Paulo: Faculdade de Ciências Farmacêuticas; 1999.

56. (99M04) Zanon CA. Avaliação dos procedimentos de higienização de equipamentos, utensílios, mobiliário e mãos de funcionários pertencentes a uma unidade de alimentação e nutrição [dissertação de mestrado]. São Paulo: Faculdade de Ciências Farmacêuticas; 1999.

57. (99M05) Ferrati AR. Avaliação de métodos analíticos rápidos na determinação da qualidade microbiológica de suco de laranja não pasteurizado [dissertação de mestrado]. São Paulo: Faculdade de Ciências Farmacêuticas; 1999. 
58. (99M06) Antonioli LR. Remoção da adstringência e armazenamento refrigerado de frutos de caquizeiro (Diospyros kaki L.) cv. Giombo [dissertação de mestrado]. São Paulo: Escola Superior de Agricultura "Luiz de Queiroz"; 1999.

59. (99M07) Nardin MS. Conservação de cogumelos comestíveis (Pleurotus sajor-caju) por acidificação e processamento térmico e por desidratação [dissertação de mestrado]. São Paulo: Escola Superior de Agricultura "Luiz de Queiroz"; 1999.

60. (99M08) Santos EJ. Determinação de nutrientes e contaminantes inorgânicos em café solúvel por espectroscopia de emissão atômica com plasma de argônio induzido (ICP-AES) [dissertação de mestrado]. São Paulo: Instituto de Química; 1999.

61. (99M09) Garcia-Amoedo LH. Geléia Real: Análises físico-químicas e químicas úteis para a caracterização e detecção da autenticidade ou adulteração do produto [dissertação de mestrado]. São Paulo: Faculdade de Ciências Farmacêuticas; 1999.

62. (99M10) Moreira AVB. Avaliação da atividade antioxidante de sementes de mostarda (Brassica alba, L.). I- Identificação dos principais compostos responsáveis pela inibição da oxidação [dissertação de mestrado]. São Paulo: Faculdade de Ciências Farmacêuticas; 1999.

63. (99M11) Ramos KS. Efeito do processamento sobre a concentração de ferro heme em carnes e em pulmão bovino [dissertação de mestrado]. São Paulo: Faculdade de Ciências Farmacêuticas; 1999.

64. (99D12) Nascimento FCA. Termorresistência de esporos de Clostridium sporogenes PA 3679 frente a vapor superaquecido com atividade de água menor que 1,00 [tese de doutorado]. São Paulo: Escola Superior de Agricultura "Luiz de Queiroz"; 2001. 
65. (99D13) Jaimes MIS. Efeito da irradiação e do armazenamento pósirradiação da pimenta preta (Piper Nigrum L.) na contagem de microrganismos indicadores de higiene usando métodos de análise convencionais e placas 'petrifilm' [tese de doutorado]. São Paulo: Faculdade de Ciências Farmacêuticas; 1999.

66. (99D14) Jurkiewicz $\mathrm{CH}$. Avaliação das características microbiológicas, físico químicas, e sensoriais de queijo de minas frescal elaborado com culturas probióticas de Lactobacillus acidophilus [tese de doutorado]. São Paulo: Faculdade de Ciências Farmacêuticas; 1999.

67. (99D15) Jacomino AP. Conservação de goiabas 'Kumagai' em diferentes temperaturas e materiais de embalagem [tese de doutorado]. São Paulo: Escola Superior de Agricultura "Luiz de Queiroz"; 2001.

68. (99D16) Olivo R. Carne PSE em frangos [tese de doutorado]. São Paulo: Faculdade de Ciências Farmacêuticas; 1999.

69. (99D17) Jesus RS. Estabilidade de "Minced Fish" de peixes amazônicos durante o congelamento [tese de doutorado]. São Paulo: Faculdade de Ciências Farmacêuticas; 1999.

70. (00M01) Beloti V. Fatores q podem influenciar o desempenho d métodos rápidos para enumeração de microrganismos indicadores d higiene em leite pasteurizado [tese de doutorado]. São Paulo: Faculdade de Ciências Farmacêuticas; 2000.

71. (00D02) Freitas MA. Determinação da vida de prateleira de um produto alimentício com base em avaliações sensoriais: uma proposta alternativa de modelagem estatística [tese de doutorado]. São Paulo: Escola Politécnica; 2000. 
72. (00D03) Castro VMF. Conteúdo informativo das embalagens de alimentos: um estudo exploratório internacional comparado, sob a ótica brasileira e norte-americana dos agentes de produção e consumo [tese de doutorado]. São Paulo: Faculdade de Saúde Pública; 2000.

73. (00D04) Youssef E. Produtos cárneos de umidade intermediária. Mudanças físico-químicas nos componentes que afetam a textura e cor do charque e Jerked Beff [tese de doutorado]. São Paulo: Faculdade de Ciências Farmacêuticas; 2000.

74. (00D05) Gurgel MSCCA. Efeito da radiação gama na resistência aos Staphylococcus aureus (Rosembach, 1884) e nas propriedades físicoquímicas e sensoriais do queijo Minas Frescal [tese de doutorado]. São Paulo: Centro de Energia Nuclear na Agricultura; 2000.

75. (00D06) Correia M. Microscopia alimentar de produtos industrializados de frutas, comercializados em supermercados de São Paulo, SP [tese de doutorado]. São Paulo: Faculdade de Saúde Pública; 2000.

76. (00M07) Zanutto ME. Comparação entre a biodisponibilidade do 'beta'caroteno sintético e de fonte natural (couve-manteiga): papel de fibra alimentar em animais de laboratório [dissertação de mestrado]. São Paulo: Faculdade de Ciências Farmacêuticas; 2000.

77. (00M08) Kitahara SE. Efeito do processamento e da estocagem sobre a formação de óxidos de colesterol em ovos [dissertação de mestrado]. São Paulo: Faculdade de Ciências Farmacêuticas; 2000.

78. (00M09) Taveira JA. Ocorrência de aflatoxina em amostras de leite comercializado na cidade de São Paulo [dissertação de mestrado]. São Paulo: Faculdade de Ciências Farmacêuticas; 2000. 
79. (00M10) Badolato ESG. Aspectos analíticos da determinação de ácidos graxos trans em margarinas e gorduras vegetais hidrogenadas [dissertação de mestrado]. São Paulo: Faculdade de Ciências Farmacêuticas; 2000.

80. (00M11) Rosin PM. Formação de amido resistente em alimentos armazenados sob baixa temperatura (-20 GRAUS ${ }^{\circ} \mathrm{C}$ ). Estudo "in vitro" e "in vivo" [dissertação de mestrado]. São Paulo: Faculdade de Ciências Farmacêuticas; 2000.

81. (00M12) Beisman RB. Processamento e avaliação da qualidade do néctar e néctar light de dois cultivares de pêssego adaptados ao clima subtropical [dissertação de mestrado]. São Paulo: Escola Superior de Agricultura "Luiz de Queiroz"; 2000.

82. (00M13) Nogueira MD. Análise de perigos e pontos críticos de controle no processamento de farinha de trigo integral [dissertação de mestrado]. São Paulo: Faculdade de Ciências Farmacêuticas; 2000.

83. (00M14) Abreu ES. Restaurante "por quilo": vale quanto pesa? : uma avaliação do padrão alimentar em restaurantes de Cerqueira César, São Paulo, SP [dissertação de mestrado]. São Paulo: Faculdade de Saúde Pública; 2000.

84. (00M15) Bersot LS. Freqüência de Listeria monocytogenes em mortadelas e comportamento durante o processamento industrial e estocagem [dissertação de mestrado]. São Paulo: Faculdade de Ciências Farmacêuticas; 2000.

85. (00M16) Martins EA. Avaliação da eficiência dos fornos combinados e convencionais elétrico na inativação de Salmonella sp [dissertação de mestrado]. São Paulo: Faculdade de Ciências Farmacêuticas; 2000. 
86. (00M17) Mayer MDB. Alterações microbiológicas, físico-químicas e sensoriais durante a vida-útil do camarão-rosa (Penaeus brasiliensis e Penaeus paulensis) submetido à radiação gama [dissertação de mestrado]. São Paulo: Faculdade de Ciências Farmacêuticas; 2000.

87. (00M18) Silvestre FA. Listeria monocytogenes em salmão "Gravlax": ocorrência e comportamento durante a estocagem refrigerada do produto [dissertação de mestrado]. São Paulo: Faculdade de Ciências Farmacêuticas; 2000.

88. (00M19) Andrigheto C. Disseminação de Listeria monocytogenes em uma linha de produção de "Nuggets" congelados de frango [dissertação de mestrado]. São Paulo: Faculdade de Ciências Farmacêuticas; 2000.

89. (00M20) Campregher RB. Utilização de metodologias convencional e "Simplate" para avaliação das condições microbiológicas de suco de laranja pasteurizado e não pasteurizado [dissertação de mestrado]. São Paulo: Escola Superior de Agricultura "Luiz de Queiroz"; 2000.

90. (00M21) Tavolaro P. Avaliação de metodologias rápidas para a determinação da qualidade microbiológica e da vida de prateleira de leite de cabra pasteurizado e congelado [dissertação de mestrado]. São Paulo: Faculdade de Ciências Farmacêuticas; 2000.

91. (00M22) Florio AMAS. Pesquisa de resíduo de Dietilestilbestrol (DES) em peças de fígado bovino comercializadas nas principais redes de supermercados da cidade de São Paulo SP [dissertação de mestrado]. São Paulo: Faculdade de Saúde Pública; 2000.

92. (00M23) Lucca A. Cachorro-quente comercializado em locais públicos: pontos críticos e características do mercado [dissertação de mestrado]. São Paulo: Faculdade de Saúde Pública; 2000. 
93. (01D01) Rosa CM. Purificação e mecanismo de ação de uma bacteriocina produzida por Lactobacillus sake $2 a$ isolado de lingüiça frescal [tese de doutorado]. São Paulo: Faculdade de Ciências Farmacêuticas; 2001.

94. (01D02) Santos MV. Efeitos do nível d células somáticas e de gordura no leite, da temperatura de armazenamento e da multiplicação microbiana sobre a proteólise e lipólise do leite pasteurizado [tese de doutorado]. São Paulo: Faculdade de Ciências Farmacêuticas; 2001.

95. (01D03) Moreno MLG. Avaliação do efeito combinado do processo de irradiação e da embalagem em diferentes atmosferas na qualidade microbiológica e sensorial de carne bovina (Longissimus dorsi) fresca refrigerada e congelada [tese de doutorado]. São Paulo: Faculdade de Ciências Farmacêuticas; 2001.

96. (01D04) Jakabi M. Radiossensibilidade de Salmonella spp e Vibrio parahaemolyticus incorporadas artificialmente por ostras (Crassostrea brasiliana) [tese de doutorado]. São Paulo: Faculdade de Ciências Farmacêuticas; 2001.

97. (01D05) Fuzihara TO. Freqüência e características de Salmonella em abatedouros de pequeno e médio portes da região do Grande ABC, SP [tese de doutorado]. São Paulo: Faculdade de Ciências Farmacêuticas; 2001.

98. (01D06) Nakashima SMK. Aplicação da microbiologia preditiva para modelar o crescimento de bactérias mesófilas e láticas em salsichas [tese de doutorado]. São Paulo: Faculdade de Ciências Farmacêuticas; 2001.

99. (01D07) Gutierrez EMR. Efeito da radiação gama na maturação do queijo prato [tese de doutorado]. São Paulo: Centro de Energia Nuclear na Agricultura; 2001. 
100. (01D08) Souza CRA. Interação entre "ALFA"-tocoferol e palmito de ascorbila sobre a carne bovina embalada em atmosfera modificada [tese de doutorado]. São Paulo: Faculdade de Ciências Farmacêuticas; 2001.

101. (01M09) Queiroz GM. Determinação de propriedades termofísicas do pão tipo francês durante o processo de assamento [dissertação de mestrado]. São Paulo: Escola Politécnica; 2001.

102. (01M10) Siqueira AAZC. Efeitos da irradiação e refrigeração na qualidade e no valor nutritivo da Tilápia (Oreochromis niloticus) [dissertação de mestrado]. São Paulo: Escola Superior de Agricultura "Luiz de Queiroz"; 2001.

103. (01M11) Liserre AM. Efeito combinado de bacteriocina produzida por Lactobacillus sake 2a e embalagem em atmosfera modificada no controle de Listeria monocytogenes em lingüiça frescal refrigerada [dissertação de mestrado]. São Paulo: Faculdade de Ciências Farmacêuticas; 2001.

104. (01M12) Lopes GISL. Depuração de ostra (Crassostrea brasiliana) contaminada artificialmente com Vibrio cholerae 01, Vibrio parahaemolyticus, Vibrio vulnificus e Salmonella Enteritidis [dissertação de mestrado]. São Paulo: Faculdade de Ciências Farmacêuticas; 2001.

105. (01M13) Carvalho CM. Avaliação comparativa entre o teste de redutase e contagem de microrganismos aeróbios totais e coliformes totais por metodologia convencional e pelo sistema Petrifilm em leite cru refrigerado [dissertação de mestrado]. São Paulo: Escola Superior de Agricultura "Luiz de Queiroz"; 2001.

106. (01M14) Pimentel LPS. Características físico-químicas e microbiológicas do gelo utilizado na conservação do pescado comercializado em supermercados da Grande São Paulo, Brasil, 1999 [dissertação de mestrado]. São Paulo: Faculdade de Saúde Pública; 2001. 
107. (01M15) Moreno RB. Avaliação dos níveis de histamina em sardinhas frescas comercializadas na CEAGESP de São Paulo [dissertação de mestrado]. São Paulo: Faculdade de Saúde Pública; 2001.

108. (01M16) Rios MDG. Efeitos da radiação ionizante sobre as concentrações de "ALFA"-tocoferol e acido ascórbico em alho (Allium sativum, L.) [dissertação de mestrado]. São Paulo: Faculdade de Ciências Farmacêuticas; 2001.

109. (01M17) Piedade FS. Distribuição da aflatoxina nas frações de milho contaminado obtidas após separação granulométrica e visual [dissertação de mestrado]. São Paulo: Escola Superior de Agricultura "Luiz de Queiroz"; 2001.

110. (01M18) Raia Jr RB. Influência da mastite na ocorrência de resíduos de antimicrobianos no leite [dissertação de mestrado]. São Paulo: Faculdade de Ciências Farmacêuticas; 2001.

111. (01M19) Simioni KR. Ação da radiação gama nas características físicoquímicas e sensoriais da mandioca (Manihot esculenta Crantz) minimamente processada [dissertação de mestrado]. São Paulo: Centro de Energia Nuclear na Agricultura; 2001.

112. (02M01) Araújo Junior J. Análise térmica e ensaios de colagem de adesivos "hot melt" para embalagens de congelados [dissertação de mestrado]. São Paulo: Instituto de Química; 2002.

113. (02M02) Martin AF. Armazenamento do iogurte comercial e o efeito na proporção das bactérias lácticas [dissertação de mestrado]. São Paulo: Escola Superior de Agricultura "Luiz de Queiroz"; 2002. 
114. (02M03) Arruda MC. Processamento mínimo de melão rendilhado: tipo de corte, temperatura de armazenamento e atmosfera modificada [dissertação de mestrado]. São Paulo: Escola Superior de Agricultura "Luiz de Queiroz"; 2002.

115. (02M04) Colombari V. Surto de intoxicação alimentar por Staphylococcus aureus: caracterização fenotípica e genotípica de cepas de origem humana e de alimentos [dissertação de mestrado]. São Paulo: Faculdade de Ciências Farmacêuticas; 2002.

116. (02M05) Pimentel RMA. Efeito da irradiação gama em mamão papaia (Carica papaya L.) colhido em três pontos de maturação [dissertação de mestrado]. São Paulo: Escola Superior de Agricultura "Luiz de Queiroz"; 2002.

117. (02M06) Denobile M. Análise de resíduos dos antibióticos oxitetraciclina, tetraciclina, clortetraciclina e doxiciclina, em leite, por cromatografia líquida de alta eficiência [dissertação de mestrado]. São Paulo: Faculdade de Ciências Farmacêuticas; 2002.

118. (02M07) Marques RMB. Análise sensorial e teor de ácido ascórbico de hortaliças supergeladas e in natura após diferentes métodos de cocção [dissertação de mestrado]. São Paulo: Faculdade de Saúde Pública; 2002.

119. (02M08) Audy SG. Avaliação das condições higiênico-sanitárias das feiras-livres do município de São Paulo-SP [dissertação de mestrado]. São Paulo: Faculdade de Saúde Pública; 2002.

120. (02M09) Alencar LCM. Vigilância e controle das doenças transmitidas por alimentos [dissertação de mestrado]. São Paulo: Faculdade de Saúde Pública; 2002. 
121. (02M10) Prado SPT. Contaminação por matérias estranhas e microorganismos em farináceos vendidos a granel e empacotados [dissertação de mestrado]. São Paulo: Faculdade de Medicina de Ribeirão Preto; 2002.

122. (02M11) Silva C. Merenda escolar: levantamento das condições higiênicosanitária dos locais de preparação e dos manipuladores em escolas da rede estadual de ensino de São Paulo, SP [dissertação de mestrado]. São Paulo: Faculdade de Saúde Pública; 2002.

123. (02M12) Silveira VR. O Serviço de Inspeção Federal brasileiro, frente aos novos enfoques da inspeção sanitária dos alimentos [dissertação de mestrado]. São Paulo: Faculdade de Medicina Veterinária e Zootecnia; 2002.

124. (02M13) Momesso AP. Levantamento das temperaturas de distribuição de alimentos, durante o período de serviço de bufê, em restaurantes selfservice do município de São Paulo e pesquisa de agentes patogênicos e indicadores de higiene [dissertação de mestrado]. São Paulo: Faculdade de Saúde Pública; 2002.

125. (02M14) Vanzo SP. Detecção de Staphylococcus aureus em manipuladores de alimentos: perfil de resistência e modelos de antibiograma/fenotipagem [dissertação de mestrado]. São Paulo: Faculdade de Ciências Farmacêuticas de Ribeirão Preto; 2002.

126. (02M15) Colombari V. Surto de intoxicação alimentar por Staphylococcus aureus: caracterização fenotípica e genotípica de cepas de origem humana e de alimentos [dissertação de mestrado]. São Paulo: Faculdade de Ciências Farmacêuticas; 2002. 
127. (02M16) Barancelli GV. Avaliação de métodos pra enumeração de microrganismos aeróbios mesófilos e coliformes em leite cru [dissertação de mestrado]. São Paulo: Escola Superior de Agricultura "Luiz de Queiroz"; 2002.

128. (02M17) Vanzin C. Efeito da adição de culturas sobre as características microbiológicas e a capacidade de sobrevivência de Staphylococcus aureus em salame tipo Italiano [dissertação de mestrado]. São Paulo: Escola Superior de Agricultura "Luiz de Queiroz"; 2002.

129. (02M18) Sarkis F. Avaliação das condições microbiológicas de carnes de animais silvestres no município de São Paulo [dissertação de mestrado]. São Paulo: Escola Superior de Agricultura “Luiz de Queiroz"; 2002.

130. (02M19) Silva MC. Avaliação da qualidade microbiológica de alimentos com a utilização de metodologias convencionais e do sistema SimPlate [dissertação de mestrado]. São Paulo: Escola Superior de Agricultura "Luiz de Queiroz"; 2002.

131. (02M20) Castro AP. Sobrevivência de bactérias aeróbias mesófilas, psicrotróficas, bactérias láticas e Listeria monocytogenes em salsichas submetidas a tratamento com nisina [dissertação de mestrado]. São Paulo: Faculdade de Ciências Farmacêuticas; 2002.

132. (02M21) Maykot LG. Quantificação de Aeromonas sp em amostras de ostras e relação com coliformes fecais e estreptococos fecais. Produção de enterotoxina e sensibilidade a antibióticos a partir das cepas isoladas [dissertação de mestrado]. São Paulo: Instituto de Ciências Biomédicas; 2002.

133. (02M22) Paula AMP. Detecção de Salmonella em alimentos crus de origem animal empregando os imunoensaios rápidos e o método convencional de cultura [dissertação de mestrado]. São Paulo: Faculdade de Ciências Farmacêuticas; 2002. 
134. (02M23) Lopes EA. Análise de perigos e pontos críticos de controle (APPC/HACCP) na produção de farinha de trigo: estudo microbiológico da etapa de molhagem do trigo [dissertação de mestrado]. São Paulo: Faculdade de Ciências Farmacêuticas; 2002.

135. (02M24) Bittencourt ABF. Avaliação da microbiota fúngica e determinação de aflatoxinas e fumonisinas em fubá de milho e farinha de milho comercializados no município de São Paulo, SP [dissertação de mestrado]. São Paulo: Faculdade de Saúde Pública; 2002.

136. (02M25) Gava MA. Desempenho de diferentes meios de cultura utilizados na avaliação de fungos presentes em ambientes de produção de alimentos [dissertação de mestrado]. São Paulo: Escola Superior de Agricultura "Luiz de Queiroz"; 2002.

137. (02M26) Hanashiro A. Avaliação da qualidade higiênico-sanitária e nutritiva de bentôs comercializados no bairro da Liberdade, São Paulo [dissertação de mestrado]. São Paulo: Faculdade de Saúde Pública; 2002.

138. (02M27) Cella AL. Ocorrência de agrotóxicos organofosforados e organoclorados dicofol em maçãs (Malus domestica) [dissertação de mestrado]. São Paulo: Centro de Energia Nuclear na Agricultura; 2002.

139. (02D28) Zanardi AMP. Avaliação da qualidade microbiológica de refeições servidas a bordo de aeronaves [tese de doutorado]. São Paulo: Faculdade de Saúde Pública; 2002.

140. (02D29) Carmo LF. Biossegurança de sucos de frutas processados, frente a Escherichia coli 0157: H7, coliforme e bactérias lácticas [tese de doutorado]. São Paulo: Escola Superior de Agricultura "Luiz de Queiroz"; 2002. 
141. (02D30) Marques PAHF. Expressão de proteínas de membrana externa por Escherichia coli O157: H7 submetida a diferentes condições de estresse [tese de doutorado]. São Paulo: Faculdade de Ciências Farmacêuticas; 2002.

142. (02D31) Sousa WA. Secagem de bananas utilizando microondas [tese de doutorado]. São Paulo: Faculdade de Ciências Farmacêuticas; 2002.

143. (02D32) Ferrari CKB. Avaliação da capacidade antioxidante total (CAT)e colorimetria de vinte e um diferentes tipos de alimentos comercializados no município de São Paulo, SP [tese de doutorado]. São Paulo: Faculdade de Saúde Pública; 2002.

144. (02D33) Germano MIS. Promoção da saúde: desafio para os profissionais envolvidos no treinamento de manipuladores de alimentos [tese de doutorado]. São Paulo: Faculdade de Saúde Pública; 2002.

145. (02D34) Makiya IK. Proposta de um sistema evolutivo de qualificação para indústrias de alimentos [tese de doutorado]. São Paulo: Escola Politécnica; 2002.

146. (02D35) Mendes CM. Disposição de pagar por alimentos seguros: o caso dos hortifrutícolas sem resíduos de agrotóxicos [tese de doutorado]. São Paulo: Escola Superior de Agricultura "Luiz de Queiroz"; 2002.

147. (03M01) Pedro SCM. Avaliação da qualidade higiênico-sanitária dos locais de venda e de amostras de queijo minas meia cura, comercializado na cidade de São Paulo [dissertação de mestrado]. São Paulo: Faculdade de Saúde Pública; 2003.

148. (03M02) Lemes VRR. Avaliação de resíduos de ditiocarbamatos e etileotiouréia (ETU) em fruta e sua implicação na saúde pública [dissertação de mestrado]. São Paulo: Faculdade de Saúde Pública; 2003. 
149. (03M03) Silva RC. Qualidade tecnológica e estabilidade oxidativa de farinha de trigo e fubá irradiados [dissertação de mestrado]. São Paulo: Escola Superior de Agricultura “Luiz de Queiroz"; 2003.

150. (03M04) Soccol MCH. Otimização da vida útil da tilápia cultivada (Oreochromis niloticus), minimamente processada e armazenada sob refrigeração [dissertação de mestrado]. São Paulo: Escola Superior de Agricultura "Luiz de Queiroz"; 2003.

151. (03M05) Garcia FT. Desenvolvimento e caracterização de filmes a base do músculo de tilápia-do-Nilo e tilápia tailandesa [dissertação de mestrado]. São Paulo: Faculdade de Zootecnia e Engenharia de Alimentos; 2003.

152. (03M06) Oliveira JTGSB. Melhor dose e dose econômica de TBHQ nos óleos de milho e canola [dissertação de mestrado]. São Paulo: Escola Superior de Agricultura "Luiz de Queiroz"; 2003.

153. (03M07) Cruz CD. Uso da PFGE (pulsed-field electrophoresis) para traçar a disseminação de Listeria monocytogenes em uma linha de produção de salmão "gravlax" [dissertação de mestrado]. São Paulo: Faculdade de Ciências Farmacêuticas; 2003.

154. (03M08) Lourenço RC. Discussão sobre o risco das interações de agrotóxicos na dieta brasileira [dissertação de mestrado]. São Paulo: Faculdade de Saúde Pública; 2003.

155. (03M09) Moda EM. Produção de Pleurotus sabor caju em bagaço de cana-de-açúcar lavado e o uso de aditivos visando sua conservação "in natura" [dissertação de mestrado]. São Paulo: Escola Superior de Agricultura "Luiz de Queiroz"; 2003. 
156. (03M10) Bassetto E. Conservação de goiabas "Pedro sato" tratadas com 1-metilciclopropeno: concentrações e tempos de exposição [dissertação de mestrado]. São Paulo: Escola Superior de Agricultura "Luiz de Queiroz"; 2003.

157. (03M11) Borguini RG. Tomate (Lycopersicum esculentum Mill) orgânico: o conteúdo nutricional e a opinião do consumidor [dissertação de mestrado]. São Paulo: Escola Superior de Agricultura "Luiz de Queiroz"; 2003.

158. (03M12) Collaço JHL. Restaurantes de comida rápida: soluções à moda da casa - representações do comer em restaurantes de "comida rápida" em praças de alimentação em shopping centers [dissertação de mestrado]. São Paulo: Faculdade de Filosofia, Letras e Ciências Humanas; 2003.

159. (03M13) Guimarães CP. Estimativa dos teores de fenilalanina em sopas desidratadas instantâneas, importância do nitrogênio de origem não protéica [dissertação de mestrado]. São Paulo: Faculdade de Ciências Farmacêuticas; 2003.

160. (03M14) Praxedes PCG. Aspectos da qualidade higiênico-sanitária de alimentos consumidos e comercializados na comunidade São Remo, São Paulo, Capital [dissertação de mestrado]. São Paulo: Faculdade de Medicina Veterinária e Zootecnia; 2003.

161. (03M15) Kawasaki VM. Custo-efetividade da produção de refeições coletivas seguras sob o aspecto higiênico-sanitário em sistemas cook-chill e tradicional [dissertação de mestrado]. São Paulo: Instituto de Química; 2003.

162. (03M16) Oliveira FS. Desenvolvimento de um modelo qualitativo de análise de risco e determinação do objetivo de inocuidade alimentar para Salmonella sp. em maionese não industrializada [dissertação de mestrado]. São Paulo: Faculdade de Ciências Farmacêuticas; 2003. 
163. (03M17) Vitti MCD. Aspectos fisiológicos, bioquímicos e microbiológicos em beterrabas minimamente processadas [dissertação de mestrado]. São Paulo: Escola Superior de Agricultura "Luiz de Queiroz"; 2003.

164. (03M18) Nunes TP. Efeito da pré-cura na estabilidade microbiológica de carne mecanicamente separada e elaboração de um produto reestruturado com filés de peito de galinhas de descarte [dissertação de mestrado]. São Paulo: Escola Superior de Agricultura "Luiz de Queiroz"; 2003.

165. (03M19) Saito J. Radiações ionizantes provenientes e acelerador de elétrons na redução da população de Salmonella sp. inoculada em almôndegas congeladas de frango: avaliação da aceitação do produto pelo consumidor [dissertação de mestrado]. São Paulo: Faculdade de Ciências Farmacêuticas; 2003.

166. (03M20) Maciel V. Listeria monocytogenes em amostras cérvico-vaginais de pacientes, amostras de alimentos e refrigeradores domésticos na região de Ribeirão Preto, Brasil, ocorrência, caracterização de marcadores fenotípicos de virulência e determinação da resistência a antibióticos [dissertação de mestrado]. São Paulo: Faculdade de Ciências Farmacêuticas de Ribeirão Preto; 2003.

167. (03M21) Andrade KA. Comparação do perfil eletroforético (esterase) de cepas de Clostridium perfringens de origem bovina e aviária [dissertação de mestrado]. São Paulo: Faculdade de Saúde Pública; 2003.

168. (03M22) Lasso PRO. Uma nova técnica para conservação de alimentos frescos baseada em instrumentação eletroeletrônica automatizada [dissertação de mestrado]. São Paulo: Escola de Engenharia de São Carlos; 2003. 
169. (03D23) Chapaval L. Detecção de enterotoxinas estafilocócicas produzidas por Staphylococcus aureus no leite bovino por eletroforese capilar e identificação dos isolados enterotoxigênicos via PCR [tese de doutorado]. São Paulo: Centro de Energia Nuclear na Agricultura; 2003.

170. (03D24) Goularte L. Aplicação de processos combinados processamento mínimo e radiação ionizante - visando o aumento da segurança microbiológica de alface (Lactuva sativa L.) [tese de doutorado]. São Paulo: Faculdade de Ciências Farmacêuticas; 2003.

171. (03D25) Morengi GB. Caracterização e vida de prateleira de queijos fundidos fabricados utilizando como conservadores sorbato de potássio, nisina e lisozima [tese de doutorado]. São Paulo: Faculdade de Ciências Farmacêuticas; 2003.

172. (03D26) Pavia PC. Avaliação da qualidade microbiológica de refeições de bordo destinadas a tripulantes de aeronaves civis brasileiras [tese de doutorado]. São Paulo: Faculdade de Medicina Veterinária e Zootecnia; 2003.

173. (03D27) Worcman-Barninka D. Hambúrguer congelado de carne bovina exposto à radiação gama: influência da composição e da atmosfera na sensibilidade de Escherichia coli 0157:H7 e nos atributos sensoriais do produto [tese de doutorado]. São Paulo: Faculdade de Ciências Farmacêuticas; 2003.

174. (03D28) Machado FMS. Estratégias de concorrência da indústria alimentícia e seus desdobramentos na dimensão nutricional [tese de doutorado]. São Paulo: Faculdade de Saúde Pública; 2003. 
175. (03D29) Barboni SAV. Ocorrência de Vibrio spp potencialmente patogênicos em moluscos bivalves comestíveis comercializados nos anos 2000 a 2002 nos municípios da área de influência da Baía de Todos os Santos e Valença, Bahia - Brasil [tese de doutorado]. São Paulo: Faculdade de Saúde Pública; 2003.

176. (03D30) Sigrist JMM. Estudos fisiológicos e tecnológicos de couve-flor e rúcula minimamente processadas [tese de doutorado]. São Paulo: Escola Superior de Agricultura "Luiz de Queiroz"; 2003.

177. (03D31) Spers EE. Mecanismos de regulação da qualidade e segurança em alimentos [tese de doutorado]. São Paulo: Faculdade de Economia e Administração; 2003.

178. (03D32) Chapaval L. Detecção de enterotoxinas estafilocócicas produzidas por Staphylococcus aureus no leite bovino por eletroforese capilar e identificação dos isolados enterotoxigênicos via PCR [tese de doutorado]. São Paulo: Centro de Energia Nuclear na Agricultura; 2003.

179. (03M33) Venturinni AC. Embalagens de transporte (masterpack) com atmosfera modificada e absorvedores de oxigênio para aumento da vida útil de carne bovina [dissertação de mestrado]. São Paulo: Escola Superior de Agricultura "Luiz de Queiroz"; 2003.

180. (03M34) Neiva CRP. Obtenção e caracterização de Minced Fish de sardinha e sua estabilidade durante a estocagem sob congelamento [dissertação de mestrado]. São Paulo: Faculdade de Ciências Farmacêuticas; 2003.

181. (04D01) Froehlich A. Irradiação do ovo líquido, congelado e ovo, gema e clara em pó: redução da população de Salmonella Enteriditis e aspectos sensoriais e físico-químicos [tese de doutorado]. São Paulo: Faculdade de Ciências Farmacêuticas; 2004. 
182. (04D02) Lima GAMR. Relações entre migração e redistribuição de umidade sobre a qualidade e estabilidade do peixe pintado (Pseudoplatystoma corruscans) liofilizado [tese de doutorado]. São Paulo: Faculdade de Ciências Farmacêuticas; 2004.

183. (04D03) Silva-Sánchez SS. Crítica e reação em rede: o debate sobre os transgênicos no Brasil [tese de doutorado]. São Paulo: Faculdade de Filosofia Letras e Ciências Humanas; 2004.

184. (04D04) Kitahara SE. Efeito do processamento e da estocagem sobre a formação de óxidos de colesterol em ovos [tese de doutorado]. São Paulo: Faculdade de Ciências Farmacêuticas; 2004.

185. (04D05) Borrell JG. Análise da microbiota do leite materno "in natura" após armazenamento e aquecimento [tese de doutorado]. São Paulo: Faculdade de Medicina; 2004.

186. (04D06) Moura AFP. Efeito da radiação ionizante sobre a oxidação do colesterol em hambúrgueres de frango e bovino congelados [tese de doutorado]. São Paulo: Faculdade de Ciências Farmacêuticas; 2004.

187. (04M07) Boaratti MFG. Análise de perigos e pontos críticos de controle para alimentos irradiados no Brasil [dissertação de mestrado]. São Paulo: Instituto de Pesquisa em Energia Nuclear; 2004.

188. (04M08) Furlan EF. Vida útil dos mexilhões Perna perna cultivados no litoral norte de São Paulo: aferição dos parâmetros físico-químicos e microbiológicos [dissertação de mestrado]. São Paulo: Escola Superior de Agricultura "Luiz de Queiroz"; 2004.

189. (04M09) Esteller MS. Fabricação de pães com reduzido teor calórico e modificações reológicas ocorridas durante o armazenamento [dissertação de mestrado]. São Paulo: Faculdade de Ciências Farmacêuticas; 2004. 
190. (04M10) Bachion KG. Estudo da vida útil da bisteca suína em atmosfera modificada [dissertação de mestrado]. São Paulo: Escola Superior de Agricultura "Luiz de Queiroz"; 2004.

191. (04M11) Cibim JC. Transgênicos: uma leitura sócio-jurídico ambiental [dissertação de mestrado]. São Paulo: PROCAM; 2004.

192. (04M12) Villares LF. A rotulagem dos alimentos transgênicos no Brasil [dissertação de mestrado]. São Paulo: PROCAM; 2004.

193. (04M13) Dörr AC. O posicionamento da indústria avícola frente às restrições do mercado consumidor europeu [dissertação de mestrado]. São Paulo: Escola Superior de Agricultura "Luiz de Queiroz"; 2004.

194. (04M14) Victaliano MFPJ. Pesquisa de satisfação do consumidor utilizando-se o método kano: uma abordagem para produtos alimentícios recém lançados [dissertação de mestrado]. São Paulo: Faculdade de Ciências Farmacêuticas; 2004.

195. (04M15) Castellucci CMM. Influência do método de cocção no valor nutritivo, qualidade lipídica e formação de óxidos de colesterol em lingüiças calabresas à vácuo e granel [dissertação de mestrado]. São Paulo: Instituto de Química; 2004.

196. (04M16) Galetti FCS. Avaliação da qualidade higiênico-sanitária e segurança microbiológica de alimentos, em restaurante tipo "self service" [dissertação de mestrado]. São Paulo: Faculdade de Ciências Farmacêuticas de Ribeirão Preto; 2004.

197. (04M17) Koakuzu SN. Características nutricionais e tecnológicas de cultivares de arroz (Oryza sativa L.) branco polido e parboilizados [dissertação de mestrado]. São Paulo: Faculdade de Ciências Farmacêuticas; 2004. 
198. (04M18) Ferreira ACP. Alterações químicas e nutricionais do grão-de-bico (Cicer arietinum L.) cru irradiado e submetido à cocção [dissertação de mestrado]. São Paulo: Escola Superior de Agricultura "Luiz de Queiroz"; 2004.

199. (04M19) Ferreira AB. Conhecendo melhor a rotulagem nutricional dos alimentos: uma análise crítica [dissertação de mestrado]. São Paulo: Faculdade de Ciências Farmacêuticas; 2004.

200. (04M20) Barrera SMA. Análise qualitativa e quantitativa da rotulagem de produtos à base de creatina para praticantes de atividades físicas [dissertação de mestrado]. São Paulo: Instituto de Química; 2004.

201. (04M21) Pereira AAF. Avaliação de condições de consumo de sardinha fresca, descongelada e processada, através de substâncias que reagem com o ácido tiobarbitúrico e do nitrogênio de bases voláteis totais [dissertação de mestrado]. São Paulo: Faculdade de Ciências Farmacêuticas; 2004.

202. (04M22) Perdigão MLPG. Avaliação do processo de sanificação química na linha de produção de saladas cruas em um restaurante industrial [dissertação de mestrado]. São Paulo: Escola Superior de Agricultura "Luiz de Queiroz"; 2004.

203. (04M23) Custódio MB. A caracterização na demanda do banco de alimentos municipal de São Paulo: a exclusão social e a procura por alimentos doados institucionalmente [dissertação de mestrado]. São Paulo: Instituto de Química; 2004.

204. (04M24) Duailibi SR. Alimentos de rua em áreas hospitalares: aspectos sanitários e socioeconômicos [dissertação de mestrado]. São Paulo: Faculdade de Saúde Pública; 2004. 
205. (04M25) Saavedra del Aguila J. Processamento mínimo de rabanete: estudos físico-químicos, fisiológicos e microbiológicos [dissertação de mestrado]. São Paulo: Escola Superior de Agricultura "Luiz de Queiroz"; 2004.

206. (04M26) Martins CG. Irradiação de grão (Nasturtium oficinallis) minimamente processado: aspectos microbiológicos e sensoriais [dissertação de mestrado]. São Paulo: Faculdade de Ciências Farmacêuticas; 2004.

207. (04M27) Rosa VP. Efeitos da atmosfera modificada e da irradiação sobre as características microbiológicas, físico-químicas e sensoriais do queijo minas frescal [dissertação de mestrado]. São Paulo: Escola Superior de Agricultura "Luiz de Queiroz"; 2004.

208. (04M28) Olivieri DA. Avaliação da qualidade microbiológica de amostras de mercado de queijo mussarela, elaborado a partir de leite de búfala (Bubalus bubalis) [dissertação de mestrado]. São Paulo: Escola Superior de Agricultura "Luiz de Queiroz"; 2004.

209. (04M29) Schüller L. Microrganismos patogênicos veiculados por formigas "andarilhas" em unidades de alimentação [dissertação de mestrado]. São Paulo: Escola Superior de Agricultura “Luiz de Queiroz”; 2004.

210. (04M30) Martins EA. Indicadores de desempenho do sistema de análise de perigos e pontos críticos de controle [dissertação de mestrado]. São Paulo: Escola Superior de Agricultura "Luiz de Queiroz"; 2004.

211. (04M31) Rizzo-Benato RT. Qualidade microbiológica do leite e do sorvete de massa de uma indústria de pequeno porte do município de Piracicaba SP [dissertação de mestrado]. São Paulo: Escola Superior de Agricultura "Luiz de Queiroz"; 2004. 
212. (04M32) Giora CGB. Avaliação in vivo da qualidade protéica da soja geneticamente modificada [dissertação de mestrado]. São Paulo: Faculdade de Ciências Farmacêuticas; 2004.

213. (04M33) Santos Filho GC. Validação da esterilização de um produto protéico vegetal enlatado [dissertação de mestrado]. São Paulo: Faculdade de Ciências Farmacêuticas; 2004.

214. (04M34) Morita M. Avaliação da qualidade sanitária e pesquisa de Aeromonas spp em pesqueiros da região metropolitana de São Paulo [dissertação de mestrado]. São Paulo: Faculdade de Saúde Pública; 2004.

215. (05M01) Santos RJ. Efeito do armazenamento de polpas de frutas congeladas sobre os teores de flavonóides, vitamina $\mathrm{C}$ e atividade antioxidantes [dissertação de mestrado]. São Paulo: Faculdade de Ciências Farmacêuticas; 2005.

216. (05M02) Pacheco SMA. Estabilidade oxidativa de óleo de peixe encapsulado e acondicionado em diferentes tipos de embalagem em condição ambiente [dissertação de mestrado]. São Paulo: Escola Superior de Agricultura "Luiz de Queiroz"; 2005.

217. (05M03) Ratto AT. Tabela Brasileira de Composição de Alimentos (TBCAUSP) apoio para determinar a qualidade das informações nutricionais em rótulos de alimentos [dissertação de mestrado]. São Paulo: Faculdade de Saúde Pública; 2005.

218. (05M04) Cestari Junior A. Avaliação do potencial de aplicação do processo de irradiação para a redução de Salmonella spp. em diferentes variedades de mangas (Mangifera indica L.) minimamente processadas e avaliação da vida de prateleira [dissertação de mestrado]. São Paulo: Faculdade de Ciências Farmacêuticas; 2005. 
219. (05M05) Lira EN. Ocorrência de doenças transmitidas por alimentos no período de 1999 a 2003, em Guarapuava-PR: um levantamento epidemiológico [dissertação de mestrado]. São Paulo: Escola de Enfermagem de Ribeirão Preto; 2005.

220. (05M06) Mattos EC. Caracterização genotípica de cepas de Staphylococcus aureus recuperadas de alimentos, mãos de manipuladores de alimentos e veiculadas por formigas [dissertação de mestrado]. São Paulo: Faculdade de Saúde Pública; 2005.

221. (05M07) Bocalon EC. A transferência de metais para os alimentos e sua possível relação com a saúde do consumidor [dissertação de mestrado]. São Paulo: Escola de Engenharia de São Carlos; 2005.

222. (05M08) Cintra P. Parâmetros nutricionais e hematológicos de ratos alimentados com soja (Glycine Max L.) geneticamente modificada [dissertação de mestrado]. São Paulo: Faculdade de Ciências Farmacêuticas; 2005.

223. (05M09) Mendonça ACC. Transgênicos: opinião de professores e alunos de nível médio da área de nutrição [dissertação de mestrado]. São Paulo: Escola Superior de Agricultura "Luiz de Queiroz"; 2005.

224. (05M10) Crede RG. Estudos dos efeitos da radiação gama e de aceleradores de elétrons na detecção de grão de milho (Zea mays) geneticamente modificado [dissertação de mestrado]. São Paulo: Instituto de Pesquisa em Energia Nuclear; 2005.

225. (05M11) Silva ML. Efeito de dois métodos de cocção - água e vapor - nos parâmetros de qualidade do músculo semitendinosus [dissertação de mestrado]. São Paulo: Escola Superior de Agricultura "Luiz de Queiroz"; 2005. 
226. (05M12) Alves DOR. Percepções do consumidor de leite longa vida (UHT) sobre qualidade e segurança do produto [dissertação de mestrado]. São Paulo: Faculdade de Medicina Veterinária e Zootecnia; 2005.

227. (05M13) Siloto RC. Especiação de cobre e zinco em água de coco e a influência do processo de pasteurização sobre essas espécies [dissertação de mestrado]. São Paulo: Instituto de Química; 2005.

228. (05M14) Von Atzingen MC. Desenvolvimento de dieta enteral artesanal com hidrolisado protéico de carne e determinação de parâmetros químicos e nutricionais [dissertação de mestrado]. São Paulo: Faculdade de Saúde Pública; 2005.

229. (05M15) Correia AFK. Implementação de um sistema de qualidade para laboratório de análise sensorial baseado no sistema de boas práticas [dissertação de mestrado]. São Paulo: Escola Superior de Agricultura "Luiz de Queiroz"; 2005.

230. (05M16) Fontes LCB. Uso de solução conservadora e de películas comestíveis em maçãs da cultivar royal gala minimamente processadas: efeito na fisiologia e na conservação [dissertação de mestrado]. São Paulo: Escola Superior de Agricultura "Luiz de Queiroz"; 2005.

231. (05M17) Jomori MLL. Resistência de lima ácida "Tahiti" à baixa temperatura: tratamentos térmicos e envolvimento do etileno [dissertação de mestrado]. São Paulo: Escola Superior de Agricultura "Luiz de Queiroz"; 2005.

232. (05M18) Maciel E. Desenvolvimento e validação de metodologia analítica de multiresíduos para quantificação de resíduos pesticidas em manga (Mangifera indica) [dissertação de mestrado]. São Paulo: Interunidades em Ecologia de Agroecossistesmas; 2005. 
233. (05M19) Saldanha LA. Avaliação da atividade antioxidante in vitro de extratos de erva-mate (Ilex paraguariensis) verde e tostada e chá verde (Carmellia sinensis) [dissertação de mestrado]. São Paulo: Faculdade de Saúde Pública; 2005.

234. (05M20) Huallanco MBA. Aplicação de um sistema de classificação de carcaças e cortes e efeito pós abate da qualidade de cortes de frango criados no sistema alternativo [dissertação de mestrado]. São Paulo: Escola Superior de Agricultura "Luiz de Queiroz"; 2005.

235. (05M21) Sasaki FF. Processamento mínimo de abóbora (Cucúrbita moschata Duch.): alterações fisiológicas, qualitativas e microbiológicas [dissertação de mestrado]. São Paulo: Escola Superior de Agricultura "Luiz de Queiroz"; 2005.

236. (05M22) Almeida MCS. Avaliação dos teores de arsênio total em cação, por meio de técnicas espectrométricas [dissertação de mestrado]. São Paulo: Faculdade de Ciências Farmacêuticas; 2005.

237. (05M23) Mattos EC. Caracterização genotípica de cepas de Staphylococcus aureus recuperadas de alimentos, mãos de manipuladores de alimentos e veiculadas por formigas [dissertação de mestrado]. São Paulo: Faculdade de Saúde Pública; 2005.

238. (05M24) Sabadin LM. A doação institucional de alimentos na grande São Paulo: incentivos e entraves [dissertação de mestrado]. São Paulo: Faculdade de Economia e Administração; 2005.

239. (05M25) Cassoli LD. Validação da metodologia de citometria de fluxo para avaliação da contagem bacteriana do leite cru [dissertação de mestrado]. São Paulo: Escola Superior de Agricultura "Luiz de Queiroz"; 2005. 
240. (05M26) Cordeiro D. Qualidade do mexilhão Perna perna submetido ao processo combinado de cocção, congelamento e armazenamento [dissertação de mestrado]. São Paulo: Escola Superior de Agricultura "Luiz de Queiroz"; 2005.

241. (05M27) Rodrigues PA. Caracterização microbiológica de leite humano de banco de leite e estudo dos efeitos da pasteurização e armazenamento a $7^{\circ} \mathrm{C}$ e $35^{\circ} \mathrm{C}$ sobre população de Escherichia coli inoculada [dissertação de mestrado]. São Paulo: Escola Superior de Agricultura "Luiz de Queiroz"; 2005.

242. (05M28) Martin G. Comportamento de Salmonella em ovo em pó em função da atividade água $(\mathrm{Aa})$ e do binômio tempo $\mathrm{x}$ temperatura de armazenamento [dissertação de mestrado]. São Paulo: Instituto de Química; 2005.

243. (05M29) Salan EO. Tratamento térmico de mexilhões Perna perna como forma de assegurar a qualidade: avaliação do crescimento de Bacillus cereus e de Staphylococcus aureus [dissertação de mestrado]. São Paulo: Escola Superior de Agricultura "Luiz de Queiroz"; 2005.

244. (05M30) Lisita MO. Evolução da população bacteriana na linha de produção do queijo minas frescal em uma indústria de laticínios [dissertação de mestrado]. São Paulo: Escola Superior de Agricultura "Luiz de Queiroz"; 2005.

245. (05M31) Denadai W. Aspectos da prevalência de enteroparositoses em crianças do bairro Santo André, Vitória - ES [dissertação de mestrado]. São Paulo: Faculdade de Saúde Pública; 2005.

246. (05M32) Bettini PP. Atividade antimicrobiana de nisina e óleo essencial de orégano (Origanum vulgare L.) sobre Listeria monocytogenes isolada de alimentos [dissertação de mestrado]. São Paulo: Instituto de Química; 2005. 
247. (05M33) Matsubara EN. Condições higiênico-sanitárias de meias-carcaças de suínos após o abate e depois do resfriamento e análise da utilização de Lista de Verificação para avaliar boas práticas no abate de suínos [dissertação de mestrado]. São Paulo: Faculdade de Zootecnia e Engenharia de Alimentos; 2005.

248. (05M34) Fröder H. Emprego de um método molecular para avaliar a presença de Listeria monocytogenes em saladas de hortaliças folhosas minimamente processadas [dissertação de mestrado]. São Paulo: Faculdade de Ciências Farmacêuticas; 2005.

249. (05M35) Oliveira RPS. Condições microbiológicas e avaliação da pasteurização em amostras de leite comercializadas no município de Piracicaba - SP [dissertação de mestrado]. São Paulo: Escola Superior de Agricultura "Luiz de Queiroz"; 2005.

250. (05M36) Tsuhako VP. Irradiação de alface (Lactuva sativa L.): aspectos microbiológicos e sensoriais [dissertação de mestrado]. São Paulo: Faculdade de Ciências Farmacêuticas; 2005.

251. (05M37) Malaguti R. Novas abordagens da vigilância de doenças transmitidas por alimentos [dissertação de mestrado]. São Paulo: Faculdade de Saúde Pública; 2005.

252. (05M38) Pereira RGL. Critérios de avaliação do risco de praguicidas em alimentos vegetais como ferramenta de gerenciamento da segurança alimentar no Brasil [dissertação de mestrado]. São Paulo: Faculdade de Ciências Farmacêuticas; 2005.

253. (05M39) Vieira VS. Avaliação do potencial de aplicação do processo de irradiação na redução da população de Salmonella $s p$. inoculada em hambúrguer de carne de frango: aspectos sensoriais e vida de prateleira [tese de doutorado]. São Paulo: Faculdade de Ciências Farmacêuticas; 2005. 
254. (05D40) Bersot LS. Disseminação de Salmonella na cadeia produtiva de suínos [tese de doutorado]. São Paulo: Faculdade de Ciências Farmacêuticas; 2005.

255. (05D41) Sakate RI. Prevalência, epidemiologia, caracterização sorológica e molecular de Listeria monocytogenes isoladas na criação intensiva de novilhos superprecoces e em abatedouros frigoríficos no Estado de São Paulo [tese de doutorado]. São Paulo: Faculdade de Ciências Farmacêuticas; 2005.

256. (05D42) Nero LA. Listeria monocytogenes e Salmonella spp. em leite cru produzido em quatro regiões leiteiras no Brasil: ocorrência e fatores que interferem na sua detecção [tese de doutorado]. São Paulo: Faculdade de Ciências Farmacêuticas; 2005.

257. (05D43) Sodré GS. Características físico-químicas, microbianas e polínicas de amostras de méis de Apis mellifera L., 1758 (Hymenoptera: Apidae) dos Estados do Ceará e Piauí [tese de doutorado]. São Paulo: Escola Superior de Agricultura “Luiz de Queiroz"; 2005.

258. (05D44) Pires TCR. Alterações pós-colheita em raízes de mandioquinhasalsa (Arracacia xanthorrhiza Bancroft.): atividade enzimática, identificação de contaminante e caracterização parcial do amido [tese de doutorado]. São Paulo: Faculdade de Ciências Farmacêuticas; 2005.

259. (05D45) Resende RS. Hábito de higienização das mãos antes das refeições em restaurantes no município de Vitória - ES [tese de doutorado]. São Paulo: Faculdade de Saúde Pública; 2005.

260. (05D46) Gutierrez ASD. Danos mecânicos pós-colheita em pêssego fresco [tese de doutorado]. São Paulo: Escola Superior de Agricultura "Luiz de Queiroz"; 2005. 
261. (05D47) Figueiredo VVF. Modelo de sistema de gestão da segurança de alimentos na pequena e média empresa [tese de doutorado]. São Paulo: Escola Politécnica; 2005.

262. (05D48) Luengo RFA. Dimensionamento de embalagens para comercialização de hortaliças e frutas no Brasil [tese de doutorado]. São Paulo: Escola Superior de Agricultura "Luiz de Queiroz"; 2005.

263. (05M49) Tsuhako VP. Irradiação de alface (Lactuva sativa L.): aspectos microbiológicos e sensoriais [dissertação de mestrado]. São Paulo: Faculdade de Ciências Farmacêuticas; 2005.

264. (05M50) Pereira RGL. Critérios de avaliação do risco de praguicidas em alimentos vegetais como ferramentas de gerenciamento da segurança alimentar no Brasil [dissertação de mestrado]. São Paulo: Faculdade de Ciências Farmacêuticas; 2005.

265. (05D51) Alves RF. Ocorrência e controle de Listeria monocytogenes em pescado minimamente processado [tese de doutorado]. São Paulo: Faculdade de Ciências Farmacêuticas de Ribeirão Preto; 2005.

266. (05M52) Garcia CCB. Qualidade e inocuidade alimentar na seção de rotisseria em supermercados: um estado crítico [dissertação de mestrado]. São Paulo: Instituto de Química; 2005.

267. (06D01) Silva MFR. Desempenho, qualidade dos ovos e balanço de nitrogênio de poedeiras comerciais alimentadas com diferentes níveis de proteína bruta, metionina e lisina [tese de doutorado]. São Paulo: Faculdade de Zootecnia e Engenharia de Alimentos; 2006.

268. (06M02) Andrade SRR. Processamento mínimo de mamão (Carica papaya L.): efeitos de aditivos e atmosfera modificada na qualidade do produto [dissertação de mestrado]. São Paulo: Escola Superior de Agricultura "Luiz de Queiroz"; 2006. 
269. (06D03) Borguini RG. Avaliação do potencial antioxidante e de algumas características físico-químicas do tomate (Lycopersicon esculentum) orgânico em comparação ao convencional [tese de doutorado]. São Paulo: Faculdade de Saúde Pública; 2006.

270. (06M04) Guimarães-Lopes TG. Efeito sinergístico da radiação gama e de refrigeração na conservação do camarão-branco-do-pacífico (Litopenaeus vannamei) [dissertação de mestrado]. São Paulo: Escola Superior de Agricultura "Luiz de Queiroz"; 2006.

271. (06D05) Moura EAB. Avaliação do desempenho de embalagens para alimentos quando submetidas a tratamento por radiação ionizante [tese de doutorado]. São Paulo: Instituto de Pesquisa em Energia Nuclear; 2006.

272. (06D06) Baracat RS. Avaliação do processo por embalagem tipo atmosfera modificada na conservação da carne bovina porcionada [tese de doutorado]. São Paulo: Escola Superior de Agricultura "Luiz de Queiroz"; 2006.

273. (06D07) Charanek KH. Determinação de alguns nutrientes e contaminantes e avaliação da distribuição de alguns elementos e amostras de soja transgênica e convencional, através do acoplamento HPLC-ICP OES [tese de doutorado]. São Paulo: Instituto de Química; 2006.

274. (06D08) Moreschi ECP. Desenvolvimento e validação de métodos cromatográficos e avaliação da estabilidade de vitaminas hidrossolúveis em alimentos [tese de doutorado]. São Paulo: Faculdade de Ciências Farmacêuticas; 2006.

275. (06D09) Andreatta E. Avaliação da qualidade dos queijos Minas Frescal e tipo Mussarela produzidos com leite contendo diferentes níveis de células somáticas [tese de doutorado]. São Paulo: Faculdade de Zootecnia e Engenharia de Alimentos; 2006. 
276. (06D10) Farias LA. Avaliação do conteúdo de mercúrio, metilmercúrio e outros elementos de interesse em peixes e em amostras de cabelo e dietas de pré-escolares da região Amazônica [tese de doutorado]. São Paulo: Instituto de Pesquisa em Energia Nuclear; 2006.

277. (06D11) Andrigheto C. Disseminação de Salmonella enteriditis isoladas em uma cadeia produtiva industrial avícola: determinação do perfil de resistência a antimicrobianos e caracterização genotípica [tese de doutorado]. São Paulo: Faculdade de Ciências Farmacêuticas; 2006.

278. (06D12) Arruda GA. Perfil genotípico de Listeria monocytogenes isoladas de alimentos: análise crítica das técnicas de PCR e PFGE e importância para a saúde pública [tese de doutorado]. São Paulo: Faculdade de Saúde Pública; 2006.

279. (06M13) Santos RM. Avaliação da qualidade higiênico-sanitária de peixes comercializados em mercados municipais da cidade de São Paulo, SP [dissertação de mestrado]. São Paulo: Faculdade de Saúde Pública; 2006.

280. (06M14) Martins FO. Avaliação da qualidade higiênico-sanitária de preparações (sushi e sashimi) a base de pescado cru servidos em bufês na cidade de São Paulo [dissertação de mestrado]. São Paulo: Faculdade de Saúde Pública; 2006.

281. (06M15) Carvalho APP. Aflatoxinas: ocorrência, distribuição e estimativa de ingestão através de produtos de amendoim na cidade de Piracicaba, SP [dissertação de mestrado]. São Paulo: Escola Superior de Agricultura "Luiz de Queiroz"; 2006.

282. (06M16) Gillio CM. Enterobacter sakazakii em fórmulas lácteas infantis desidratadas, para bebês de 0-6 meses [dissertação de mestrado]. São Paulo: Faculdade de Ciências Farmacêuticas; 2006. 
283. (06M17) Almeida RR. Ocorrência de Fusarium graminearum e desoxinivalenol em grãos de trigo utilizados no Brasil [dissertação de mestrado]. São Paulo: Escola Superior de Agricultura "Luiz de Queiroz"; 2006.

284. (06M18) Monteiro SH. Desenvolvimento e validação de metodologia para determinação de resíduos de pesticidas piretróides por HPLC em feijão [dissertação de mestrado]. São Paulo: Instituto de Química; 2006.

285. (06M19) Souza CHB. Influência de uma cultura Starter termofílica sobre a viabilidade de Lactobacillus acidophilus e as características de queijo minas frescal probiótico [dissertação de mestrado]. São Paulo: Faculdade de Ciências Farmacêuticas; 2006.

286. (06M20) Ratti RP. Listeria monocytogenes em alimentos fatiados e equipamentos: ocorrência, formação de biofilme e controle [dissertação de mestrado]. São Paulo: Faculdade de Ciências Farmacêuticas; 2006.

287. (06M21) Kruger MF. Controle de Listeria monocytogenes em lingüiça frescal refrigerada através do uso de óleo essencial de orégano e nisina [dissertação de mestrado]. São Paulo: Faculdade de Ciências Farmacêuticas; 2006.

288. (06M22) Castro MRCC. Avaliação da qualidade microbiológica de leite humano cru recebido em Banco de Leite Humano [dissertação de mestrado]. São Paulo: Escola Superior de Agricultura "Luiz de Queiroz"; 2006.

289. (06M23) Penterich VRA. Desenvolvimento de preparações com hidrolisado de frango para crianças de 0 a 12 meses com reações adversas nos leites [dissertação de mestrado]. São Paulo: Faculdade de Saúde Pública; 2006. 
290. (06M24) Fonseca CR. Armazenamento do leite de cabra cru em diferentes temperaturas por diferentes períodos e influência nas qualidades microbiológica, físico-química e sensorial do produto pasteurizado [dissertação de mestrado]. São Paulo: Escola Superior de Agricultura "Luiz de Queiroz"; 2006.

291. (06M25) Silva MEM. Repercussão da informação nutricional sobre o comportamento de clientes de restaurantes universitários [dissertação de mestrado]. São Paulo: Faculdade de Saúde Pública; 2006.

292. (06M26) Bandoni DH. Índice de qualidade da refeição de empresas cadastradas no Programa de Alimentação do Trabalhador na cidade de São Paulo [dissertação de mestrado]. São Paulo: Faculdade de Saúde Pública; 2006.

293. (06M27) Castro JBJ. Efeito do jejum alimentar na qualidade da carne de frangos de corte criados em sistema convencional [dissertação de mestrado]. São Paulo: Escola Superior de Agricultura "Luiz de Queiroz"; 2006.

294. (06M28) Curi JDP. Condições microbiológicas de lanches (cachorroquente) adquiridos de vendedores ambulantes, localizados na parte central da cidade de Limeira, SP [dissertação de mestrado]. São Paulo: Escola Superior de Agricultura "Luiz de Queiroz"; 2006.

295. (06M29) Aguiar APS. Opinião do consumidor e qualidade da carne de frangos criados em diferentes sistemas de produção [dissertação de mestrado]. São Paulo: Escola Superior de Agricultura "Luiz de Queiroz"; 2006.

296. (06M30) Trindade AA. Subsídios para implementação do Sistema de Análise de Perigos e Pontos Críticos de Controle - APPCC em lactário [dissertação de mestrado]. São Paulo: Escola Superior de Agricultura "Luiz de Queiroz"; 2006. 
297. (06M31) Almeida MTT. Avaliação microbiológica de alfaces (Lactuva sativa) em restaurantes self-service no Município de Limeira - SP [dissertação de mestrado]. São Paulo: Escola Superior de Agricultura "Luiz de Queiroz"; 2006.

298. (06M32) Contri DG. Detecção de resíduos de DNA em alimentos: avaliação da qualidade, da quantidade e da capacidade de amplificação por PCR de DNA extraído de matérias-primas e produtos acabados para fins de análise de transgenia [dissertação de mestrado]. São Paulo: Faculdade de Ciências Farmacêuticas; 2006.

299. (06D33) Moraes IR. Estudo comparativo da sensibilidade de cistos de metacercárias de Phagicola Faust, 1920 (Trematoda: Heterophyidae) à radiação ionizante e ao congelamento em peixes crus preparados a partir da Tainha Mugil Linnaeus, 1758 (Pisces: Mugilidae) [tese de doutorado]. São Paulo: Instituto de Pesquisa em Energia Nuclear; 2006.

300. (06M34) Pires CC. Efeitos das radiações gama e ultra-sônica em suco de laranja contaminado por Alicyclobacillus acidoterrestris [dissertação de mestrado]. São Paulo: Escola Superior de Agricultura "Luiz de Queiroz"; 2006.

301. (06M35) Contri DG. Detecção de resíduos de DNA em alimentos: avaliação da qualidade, da quantidade e da capacidade de amplificação por PCR de DNA extraído de matérias-primas e produtos acabados para fins de análise de transgenia [dissertação de mestrado]. São Paulo: Faculdade de Ciências Farmacêuticas; 2006.

302. (06M36) Mucke D. Efeitos da posição da carcaça durante o resfriamento da carne bovina [dissertação de mestrado]. São Paulo: Faculdade de Zootecnia e Engenharia de Alimentos; 2006. 
303. (06M37) César MLVS. Doença diarréica aguda: aspectos epidemiológicos e vigilância no município de Avaré, interior do estado de São Paulo [dissertação de mestrado]. São Paulo: Faculdade de Saúde Pública; 2006.

304. (07M01) Silva, ML. Pesquisa de Aeromonas spp., Vibrio spp. e da qualidade sanitária de peixes comercializados na cidade de São Paulo [dissertação de mestrado]. São Paulo: Faculdade de Saúde Pública; 2007.

305. (07M02) Brossi, C. Qualidade da carne de frango: efeito do estresse severo pré-abate, classificação pelo uso da cor e marinação [dissertação de mestrado]. São Paulo: Escola Superior de Agricultura "Luiz de Queiroz"; 2007.

306. (07M03) Oliveira ACG. Efeitos do processamento térmico e da radiação gama na estabilidade físico-química, microbiológica e sensorial de caldo de cana puro e adicionado de suco de frutas, armazenado sob refrigeração [dissertação de mestrado]. São Paulo: Escola Superior de Agricultura "Luiz de Queiroz"; 2007.

307. (07M04) Matsumura EM. Perspectivas para a conservação e reuso da água na indústria de alimentos - estudo de uma unidade de processamento de frangos [dissertação de mestrado]. São Paulo: Escola Politécnica; 2007.

308. (07M05) Kechichian V. Adição de ingredientes antimicrobianos em filmes biodegradáveis à base de fécula de mandioca [dissertação de mestrado]. São Paulo: Escola Politécnica; 2007.

309. (07D06) Arruda MC. Processamento mínimo de laranja "pêra" [tese de doutorado]. São Paulo: Escola Superior de Agricultura "Luiz de Queiroz"; 2007. 
310. (07M07) Cancelliero AC. Detecção da origem das matérias graxas presentes em requeijões e similares encontrados no mercado [dissertação de mestrado]. São Paulo: Escola Superior de Agricultura "Luiz de Queiroz"; 2007.

311. (07M08) Zanão CFP. Características físico-químicas e sensoriais do arroz (Oryza sativa L.) irradiado e o efeito no desenvolvimento de Sitophilus oryzae L. [dissertação de mestrado]. São Paulo: Escola Superior de Agricultura "Luiz de Queiroz"; 2007.

312. (07M09) Franco MJM. Aplicação da metodologia APPCC - análise de perigos e pontos críticos de controle - como ferramenta para reuso de água na indústria: modelo para indústria de aromas e essências [dissertação de mestrado]. São Paulo: Escola Politécnica; 2007.

313. (07M10) Carvalho OT. Carotenóides e composição centesimal de ervilhas (Pisum sativum L.) cruas e processadas [dissertação de mestrado]. São Paulo: Faculdade de Ciências Farmacêuticas; 2007.

314. (07D11) Umisedo NK. Dose de radiação ionizante decorrente do uso de fertilizantes agrícolas [tese de doutorado]. São Paulo: Faculdade de Saúde Pública; 2007.

315. (07M12) Sangaletti N. Estudo da vida útil do queijo minas frescal disponível no mestrado [dissertação de mestrado]. São Paulo: Escola Superior de Agricultura "Luiz de Queiroz"; 2007.

316. (07D13) Lemes VRR. Avaliação de resíduos de etilenotiouréia (ETU) em frutas comercializadas na cidade de São Paulo [tese de doutorado]. São Paulo: Faculdade de Saúde Pública; 2007.

317. (07M14) Leme AC. Avaliação e armazenamento de híbridos de milho verde visando a produção de pamonha [dissertação de mestrado]. São Paulo: Escola Superior de Agricultura "Luiz de Queiroz"; 2007. 
318. (07M15) Stranghetti BG. Monitoração toxicológica do pescado comercializado nos municípios de São Sebastião e Caraguatatuba, SP [dissertação de mestrado]. São Paulo: Instituto de Biociências; 2007.

319. (07M16) Palcich G. Ocorrência de Enterobacter sakazakii no ambiente de lactários de maternidades da Grande São Paulo [dissertação de mestrado]. São Paulo: Faculdade de Ciências Farmacêuticas; 2007.

320. (07M17) Franco FO. Efeito das variações térmicas na perda de umidade em carcaças de frango [dissertação de mestrado]. São Paulo: Instituto de Química; 2007.

321. (07M18) Bíscola V. Influência da matriz no efeito antimicrobiano de óleo essencial de orégano e nisina contra Listeria monocytogenes: avaliação em modelos [dissertação de mestrado]. São Paulo: Faculdade de Ciências Farmacêuticas; 2007.

322. (07M19) Lobanco CM. Rotulagem nutricional de alimentos salgados e doces consumidos por crianças e adolescentes [dissertação de mestrado]. São Paulo: Faculdade de Saúde Pública; 2007.

323. (07M20) Nogueira FAG. Disponibilidade de cálcio em leite adicionado de outros alimentos [dissertação de mestrado]. São Paulo: Escola Superior de Agricultura "Luiz de Queiroz"; 2007.

324. (07M21) Ravagnani EM. Subsídios à implementação do sistema de análises de perigos e pontos críticos de controle em unidades de alimentação e nutrição [dissertação de mestrado]. São Paulo: Escola Superior de Agricultura "Luiz de Queiroz"; 2007.

325. (07D22) Souza ARM. Efeitos da irradiação no aspecto nutricional e químico de carnes [dissertação de mestrado]. São Paulo: Centro de Energia Nuclear na Agricultura; 2007. 
326. (07M23) Romero AC. Mensuração de biomarcador de exposição às aflatoxinas em fluídos biológicos [dissertação de mestrado]. São Paulo: Escola Superior de Agricultura "Luiz de Queiroz"; 2007.

327. (07D24) Santaella SRS. Controle de soluções sanificantes por meio do potencial de óxido-redução em alface americana minimamente processada [tese de doutorado]. São Paulo: Faculdade de Saúde Pública; 2007.

328. (07M25) Groppo VD. Laranja pêra (Citrus sinensis L. Osbeck) minimamente processada: efeito de cloreto de cálcio e película de alginato de sódio na fisiologia e conservação [dissertação de mestrado]. São Paulo: Escola Superior de Agricultura “Luiz de Queiroz"; 2007.

329. (07M26) Barretto TL. Perfil epidemiológico dos surtos de toxinfecções alimentares no município de Limeira - SP [dissertação de mestrado]. São Paulo: Escola Superior de Agricultura "Luiz de Queiroz"; 2007.

330. (07M27) Piedade KR. Uso de ervas aromáticas na estabilidade oxidativa de filés de sardinha (Sardinella brasiliensis) processados [dissertação de mestrado]. São Paulo: Escola Superior de Agricultura "Luiz de Queiroz"; 2007.

331. (07D28) Siqueira AAZC. Utilização de radiação gama em melões cataloupe (Cucumis melo L. var. Cantaloupensis) como técnica de conservação pós-colheita [tese de doutorado]. São Paulo: Centro de Energia Nuclear na Agricultura; 2007.

332. (07D29) Molinari ACF. Métodos combinados para preservar a qualidade pós-colheita do mamão "Golden" tipo exportação [tese de doutorado]. São Paulo: Centro de Energia Nuclear na Agricultura; 2007.

333. (07M30) Zago G. Relação entre escolha de alimento para o fungo e a umidade da colônia em Atta sexdens rubrapilosa [dissertação de mestrado]. São Paulo: Instituto de Psicologia; 2007. 
334. (07D31) Sugai AY. Processamento contínuo de purê de manga (Mangifera indica Linn.), variedade palmer [tese de doutorado]. São Paulo: Escola Politécnica; 2007.

335. (07M32) Uegama LH. Validação do sistema de análise de perigos e pontos críticos de controle em um serviço de comissária aérea [dissertação de mestrado]. São Paulo: Faculdade de Ciências Farmacêuticas; 2007.

336. (07M32) Rojas MVR. Caracterização por meio de métodos moleculares de cepas ambientais de Vibrio parahaemolyticus isoladas no Brasil [dissertação de mestrado]. São Paulo: Faculdade de Saúde Pública; 2007.

337. (07M33) Shibasaki SH. A geração de resíduos sólidos na importação de produtos de interesse à saúde, no contexto da Vigilância Sanitária [dissertação de mestrado]. São Paulo: Faculdade de Saúde Pública; 2007. 


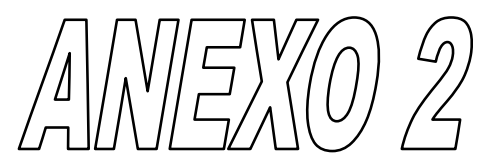

Primeira página do Currículo Lattes da autora. 


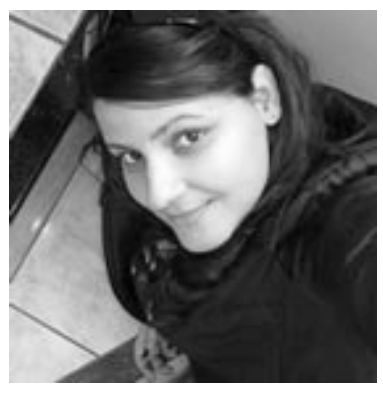

\section{Vanessa Fernandes Ribeiro}

Possui graduação em Nutrição pela Universidade do Vale do Itajaí - UNIVALI (2003). Tem experiência na área de Nutrição com ênfase em Administração de Cozinhas Industriais, Vigilância Sanitária e Controle Higiênico-Sanitário de Alimentos. Atualmente é mestranda em Saúde Pública na Faculdade de Saúde Pública da Universidade de São Paulo (FSP-USP), na área de concentração Serviços de Saúde Pública.

(Texto informado pelo autor) Última atualização em 05/09/2008

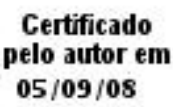

Endereço para acessar este CV: http://lattes.cnpq.br/7730669589011444 


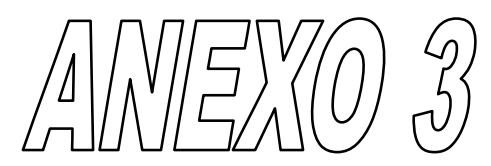

Primeira página do Currículo Lattes do orientador. 


\section{Glavur Rogerio Matté}

Possui graduação em Farmácia-Bioquímica pela Universidade Estadual de Ponta Grossa (1982), graduação em Licenciatura em Ciências pela Universidade Estadual de Ponta Grossa (1980), especialização em Saúde Pública pela Universidade de São Paulo (1986), mestrado em Farmácia (Análises Clínicas) pela Universidade de São Paulo (1987), doutorado em Saúde Pública pela Universidade de São Paulo (1993) e pós-doutorado pela University of Maryland System (1998). Atualmente é Professor Associado Referência MS-5 da Universidade de São Paulo. Tem experiência na área de Saúde Coletiva, com ênfase em Saúde Pública. Atuando principalmente nos seguintes temas: Saúde Pública, Vigilância Sanitária, Laboratório de Saúde Pública, Biologia molecular de microrganismos de interesse em Saúde Pública.

(Texto gerado automaticamente pela aplicação CVLattes)

Última atualização do currículo em 18/08/2008

Certificado

pelo autor em

18/08/08

Endereço para acessar este CV:

http://lattes.cnpq.br/8985024921749518 